\title{
المضامين التربوية المستنبطة من قصة ابني آدم عليه السلام
}

\section{وتطبيقاتها التزبوية في الأسرة}

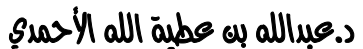

أستاذ الثقافة الإسلامية المساعد

\section{بقسم الثقافة الإسلامية والمهارات اللفوية}

\section{كلية العلوم والآداب فرع رابغ - جامعة الملك عبدالعزيز}

$$
\begin{aligned}
& \text { الملغـسص: } \\
& \text { هدفت الدراسة إلى التعريف بقصة ابنهي آدم عليه السلام الواردة في القرآن الكريم، واستنباط المضامين التربوية } \\
& \text { الواردة فيها في الجانب العقدي والتعبدي، وفي الجانب الأخلافي والاجتماعي، وذكر بعض التطبيقات التربوية }
\end{aligned}
$$

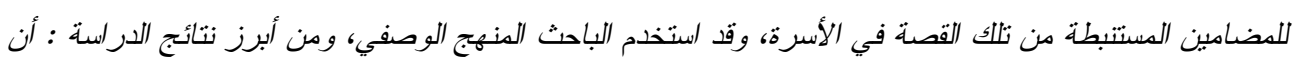

$$
\begin{aligned}
& \text { صنة ابني آدم علبه السلام احتوت على مجموعة من المضامبن التربوية في الجوانب العقلية والتعبدية، والأخلاقية } \\
& \text { و الاجتماعية. وأن التربية عملية مقصودة قديمة قام بها آدم عليه السلام، وأن الحسد داء قديم وأثره عظبم، وأن القتل }
\end{aligned}
$$

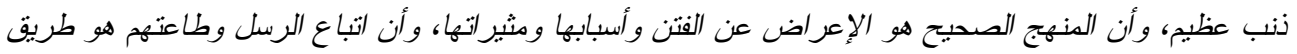

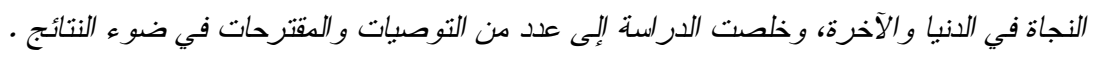

$$
\begin{aligned}
& \text { الكلمات المفتاحية : المضامين التربوية ، قصنة ابني آدم . }
\end{aligned}
$$

\section{Abstract}

The study aimed to introduce the story of the sons of Adam, peace be upon him, in the Holy Quran, and to devise the educational contents contained therein in the doctrinal, Worship, ethical, and social aspects, and mentioned some educational applications of the contents derived from that story in the family, and the researcher has used the descriptive approach, and the main results of the study: The story of the son of Adam (peace be upon him) contains a set of educational contents of the doctrinal, Worship, ethical and social aspects, and on the old practical education by Adam peace be upon him, and that the envy is an old disease and its effect is great, and that the murder is a great sin, and that the correct approach is to Stay away of the sedition, its causes and effects, and that following the apostles and obedience them is the way of survival in this world and afterlife, and the study concluded with a number of recommendations and proposals in light of the results.

Keywords : Educational contents, The story of the two sons of Adam.

$$
\begin{aligned}
& \text { منها أسلوب القصة؛ لما لها من أثز في نفوس }
\end{aligned}
$$

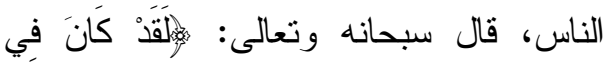

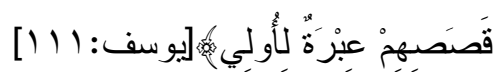

$$
\begin{aligned}
& \text { "و لاشك في أن قصص القرآن الكريم فيه } \\
& \text { من الناحية الفنية معظم ما اتفق عليه دارسو } \\
& \text { الآداب من عناصر فنية كالزمان و المكان }
\end{aligned}
$$

\section{مقدمة اللدراسة :}

إن كتاب الله سبحانه وتعالى، نزل لكي

نتدبر ه، ونأخذ العظة منه، ونمنتل توجيهاته،

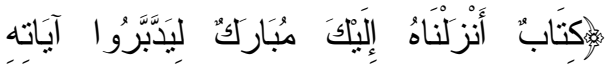

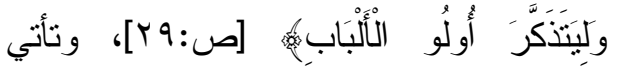
العظات في كتابه الحكيم بأساليب مختلفة، 
و المضامين الثربوية في القرآن الكريم

كانت ولا نز ال محط أنظار الدارسين في

التربية الإسلامية، لأنها تتصل بتولية لتوليهات

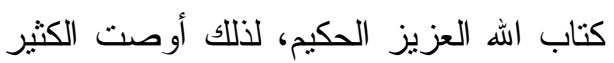

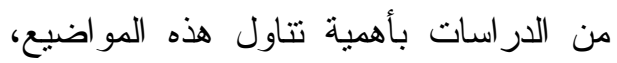

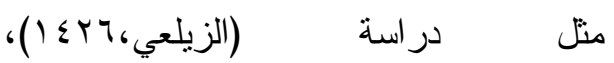

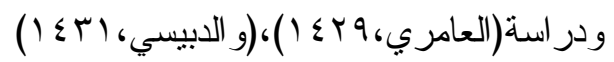
الذي نص في مقترحاته على "مواصلة البحوث التربوية المتعلقة في دئه

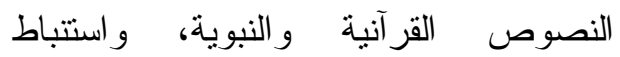
المضامين و المبادئ التربوية، نظر اً لاثتنمالها ولئه على الكثبر من المضامين و القيم الثاملة لجميع جو انب الحياة، ومن ثم تكوين موسوعة عن المضامين التزبوية المستتبطة من سور

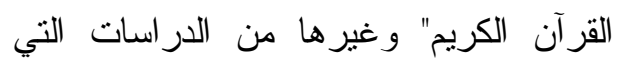
تؤكد على ذلك.

ومن هنا يأتي الدور المستمر للباحثين في " البحث و التقصي عن المبادئ و القيم التربوية المتضمنة في القرآن الكريم، و السنة النبوية باعتبار هما المصدرين الأولين و الأساسيين في الثريعة الإسلامية، وذلك من أجل تأصيل تلك المبادئ و القيم و إيجاد

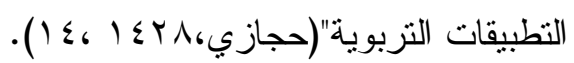

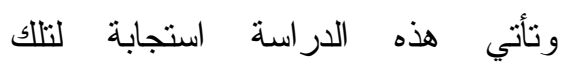
المطالب، و لأهمية الدراسات المتصلة بكتاب الله سبحانه وتعالى، و التي تنستبط منه لهنه مضامينه التزبوية، التي تساهم في توجيه
و الأحداث و الصراع و الأشخاص وله من الناحية الموضوعية أهداف كثيرة، لعل الهدف ولاحف التربوي من أهمها لما ينضوي تحته من قيم ثرة، وعطاء سام متجدد للدعاة و المربين،

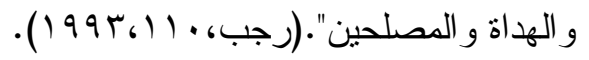
وقصة ابني آدام عليه السلام التي خلدها القرآن بذكرها في كتابه العزيز مليئة بالفو ائد

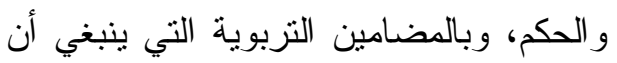

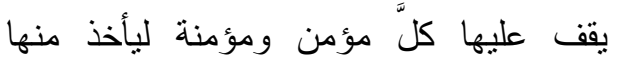
الدروس و العبر، و لاسيما وهي تحكي حو اراً بين أخوين كان التنافس فيه سيد الموقف، ولهي

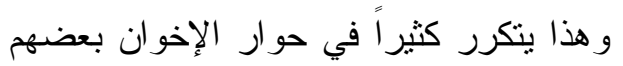

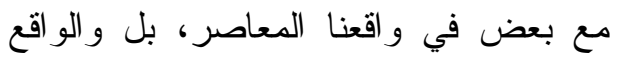
يشهد لكثير من الوقائع التي يقع فيها الثحناء بين حوار ات الإخوان. إن قصة ابني آدم عليه السلام تتناول أول الإن حالة حسد، وأول حالة قتل وقعت بين البشر ، أنها وتحمل في طياتها الكثير من المعاني و المضامين المهمة، فهي جديرة بالاهتمام و الدراسة و الغور في أعماق هذه القصة، و استتباط المضامين التربوية دنها لإصلاح هذه النفوس التي تتشابه فيها طباع البشر ، و لا

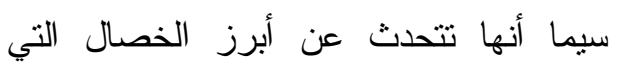

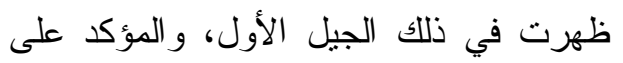

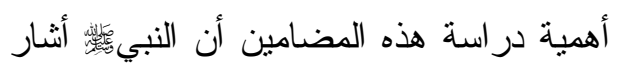
إلى بعض هذه المضامين كما هو بين طيات البحث. 
السؤال الأول: ما المضامين التربوية

المستتبطة من قصة ابني آدم عليه السلام في لاولين

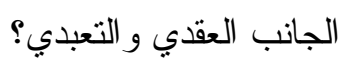

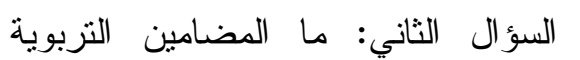
المستتبطة من قصة ابني آدم عليه السلام في ماني الجانب الأخلاقي و الاجتماعي؟

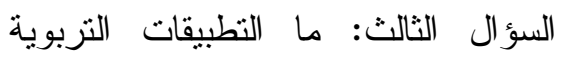
للمضامين المستتبطة من قصة ابني آدم عليه السلام في الأسرة؟ - إمبن

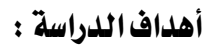

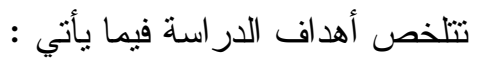
التعريف بقصة ابني آدم عليه السلام الواردة في القر آن الكريم.

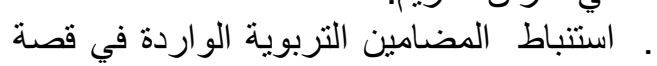
ابني آدم عليه السلام في الجانب العقدي العيد

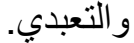

استتباط المضامين التربوية الواردة في التي قصة ابني آدم عليه السلام في الجئية الجانب الأخلافي والاجتماعي. ك. ذكر بعض التطبيقات التربيت التربية للمضامين المستنبطة من قصة ابني آدم عليه السلام في لئرئ

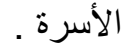

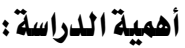

تظهر أهمية الدر اسة من خلال ما يلي:

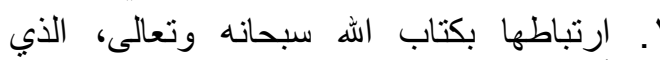
أمرنا بتدبره و التفكر في آياته. r. أنها تتحدث عن أول حالة حسد وقتئه وقتل وقعت $r$

إن القرآن الكريم هو المصدر الأول للتربية الإسلامية، فهو يتتاول جميع جوانب النزبية،

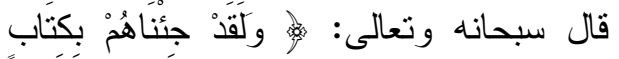

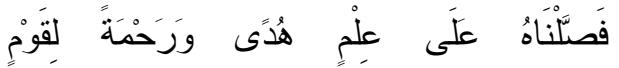

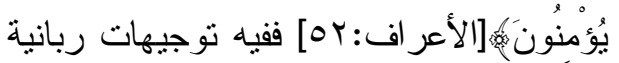
تتتاولها الآيات العطر ات لإصلاح الإنسان في حياته الأسرية، والاجتماعية، ليبقى الإنسان على خلق عظيم، وقد وصفت أم المؤمنين

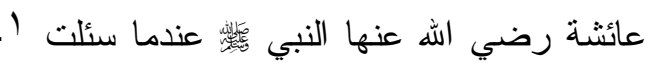

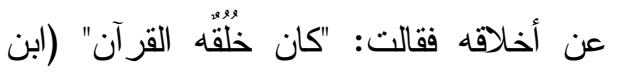
حنبل، (... و هذا يدعونا إلى الاهتمام بالمضامين التربوية التي ترد في كتابه الكريم وبيانها و الاستفادة منها، كما هو الحال مع أحكامه الفقهية

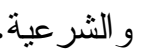
ستجيب الدراسة عن السؤال الرئيس التالي:

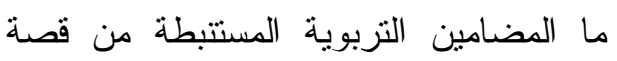

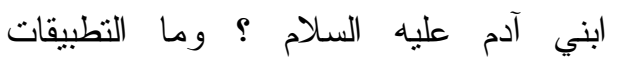
التزبوية لها في الأسرة؟ النج

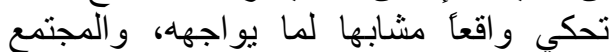
يعيش حالات مثز ايدة من حالات الحسد والقابل القتل لأسباب قد تتشابه مع بنز دن حالات جوانب هذه القصة. ع. استكمالا لما بدأ به الباحثون في كتابة 
تربوية مُدعَّمة بالأدلة الواضحة

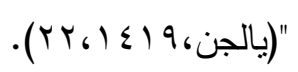

وسيقوم الباحث بدر اسة الآيات من رقم

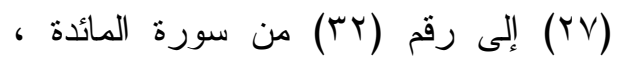
و الرجوع إلى كلام أهل العلم في تفسير هذه

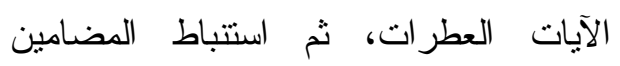

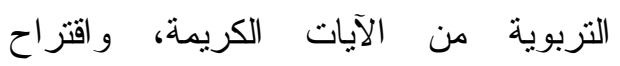
التطبيقات التربوية المناسبة لها في الأسرة.

\section{حلدود الدراسة : - م}

تتتاول هذه الدراسة الآيات المباركات من

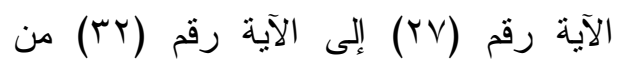

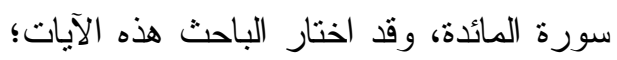

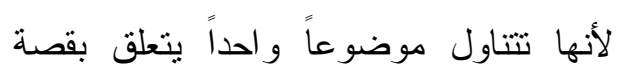
ابني آدم عليه السلام.

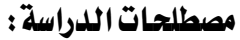

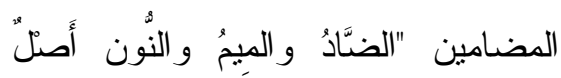

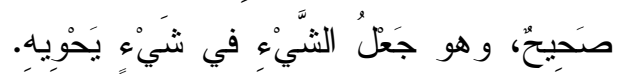

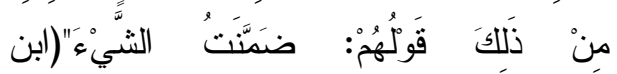

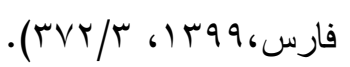

الاسنتباط من النبط، يقال:" نَبَطَ الماءُ

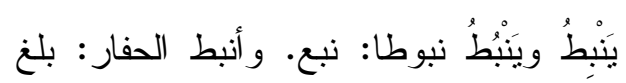

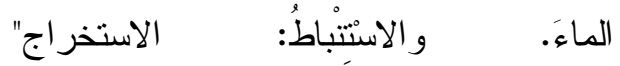

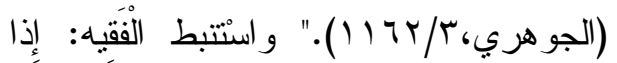

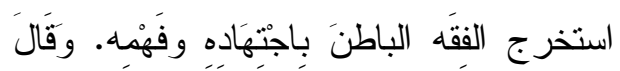

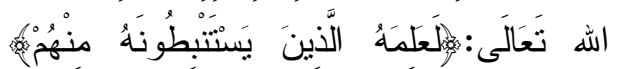

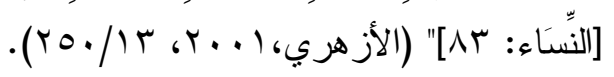

المضامين التربوية المستتبطة من كتاب الله

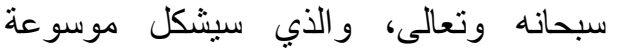
تربوية مستنبطة منه.

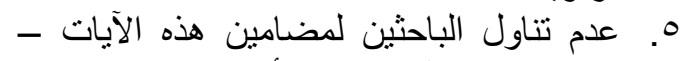
حسب اطلاع الباحثـ- مع أهمية مضامينها. لهذيا.

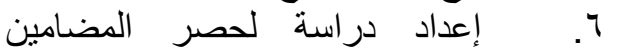
التربوية المسنتبطة من القرادية آن الكريم والتي التين ينبغي العناية بها من قبل المؤسسات التربوية في المجتمع .

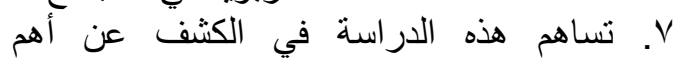
المضامين التربوية التي ينبخي على التئ المؤسسات التربوية العناية بها، وبناء برامجها التها التربوية لغرسها، ولا سيما مع ما نراه من من سلوكيات

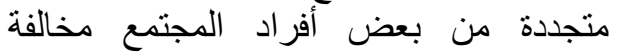
لتوجيهات التربية الإسلامية.

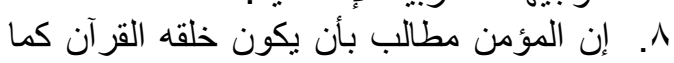

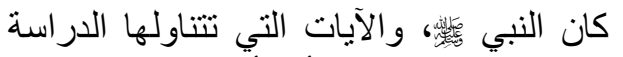
تحكي سلوكَ كأ عمليًا في أهم أُخلاقيات المؤمنين.

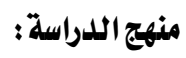

سيستخدم الباحث المنهج الوصفي، لأنه هو المنهج المناسب لهذه الدراسة .

و المنهج الوصفي هو المنهج الذي "يسعى لهن

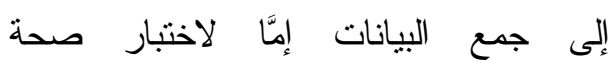
الفرضيات التي تصف الوضع الحالي للفرد موضوع الدراسة أو للإجابة عن الأسئلة

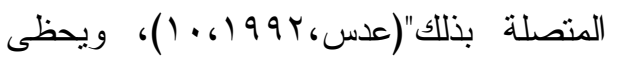
المنهج الوصفي بمكانة خاصة في مجال البحوث التربوية. و لاستتباط المضامين التربوية من الآيات الكريمات سيستخدم الباحث طريقة الاستتباط، و المنهج الاستتباطي هو : "الطريقة التي يقوم بها الباحث ببذل أقصى جهد عقلي ونفسي هون الاسنياطي عند در اسة النصوص بهدف استخر اج مبادئ 
و المجتمع، وذلك باسنتباط المضامين التربوية التي تشع بها سورة الضحى، و واستخدم الباحث المنهج الاستتباطي، وكان من نتائج الدراسة: أن سورة الضحى وإن جاءت تنلية وتسرية للنبي كل مؤمن، وأن الوقت في الإسلام هو الحياة، لَّل

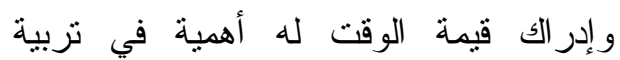
الناشئة، و وأن الرفق و اللين من الأخلاق

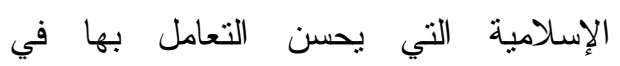
المجتمع، وأن الفقر من القضايا التي اعتتى لإنى

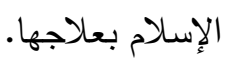

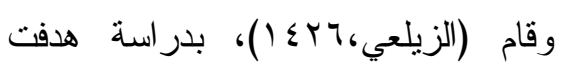

إلى استتباط المضامين التزبوية لسورة الفاتحة وتطبيقاتها التربوية، وبيان أهم الآثار التربوية

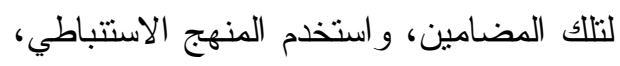
وتوصلت الدراسة إلى مجموعة من النتائج،

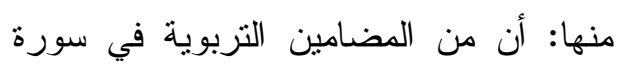
الفاتحة في المجال العقدي هي : الإيمان باله،

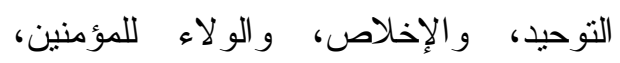
و البراء من الكافرين، وأن المضامين التربوية ولاءية الإهية في سورة الفاتحة في الجانب الأخلاقي و السلوكي هي: الرحمة، و العدل، و التو اضع.

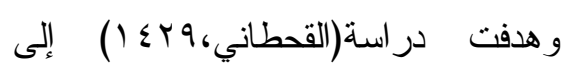

استتباط المضامين التزبوية وتطبيقاتها على دهانى الأسرة والمجتمع من خلال سورة الماعون، واستخدم الباحث المنهج الاستتباطي، وكان من أبرز نتائج الدراسة: إن سورة الماعون
ومن خلال التعاريف اللغوية السابقة يظهر أن المضمون هو في باطن الثيء،

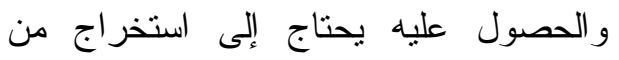
خلال تحليله إلى أجزاء بإعمال الفكر و التدبر فيه. و المضامين التربوية بشكل عام هي خلاصة الفكر التربوي الذي يشتمل عليه كتاب معين، بغض النظر عن المجال الرئيس الذي ألف فيه، فقد يكون الكتاب مرجعاً فقهياً، أو أدبياً، أو تاريخياً بالدرجة الأولى، إلا أنه فئ لا يخلو من فكر نربوي متضدن في ثناياه ويمكن الإفادة

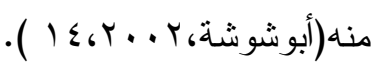

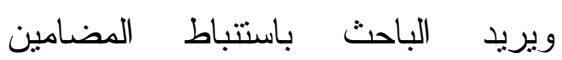
التربوية : استخراج المضامين التربوية الموجودة في قصة ابني آدم عليه السلام بعد الداجين تحليل الآيات و الرجوع إلى تفسير أهل العلم الدراسات السابقة : اللَّع الباحث على مجموعة من الدِّراسات الستّابقة ذات العلاقة بموضوع الإح استة الحالية

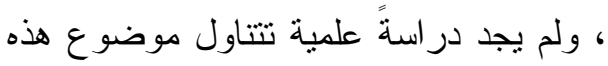

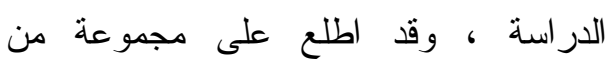
الدراسات التي تتاولت المضامين التربوية الوارد في القرآن الكريم ، منها ما يأتي:

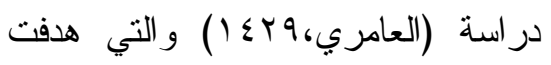
إلى بيان ما للقرآن من آثار في بناء الفرد، 
سورة القلم في محيط الأسرة قولاًا وعملاً يؤدي إلى نجاح الآباء و الأمهات في العملية التزبوية وتقويم السلوك.

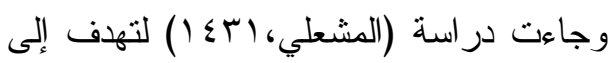
استخلاص المضامين التزبوية التي تضمنتها قصص الأنبياء سورة هود، وقد استخدم

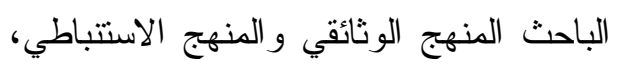
ونوصلت الدراسة إلى عدد من النتائج كان من أبرزها: التَّصَّل إلى أهداف عدئ عديدة ومتنوعة سعى الأنبياء عليهم السلام لتحقيقها،

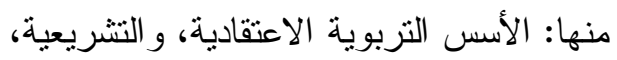
و النفسية، كما توصلت إلى طبيعة العلاقة التسنة و الارتباط بين العقيدة و الأخلاق و وأنهما منر ابطتان ارتباطاً قوياً، كما توصلت الدر اسة الأن إلى ثقرير نظرة الإسلام إلى الكون و الحياة

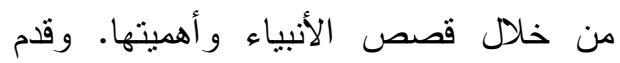

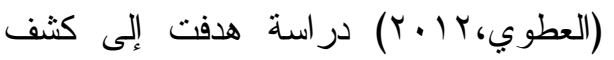
المضامين التربوية في قصة موسى عليه

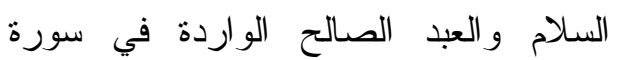
الكهف، و التعرف على صفات وسمات العالم

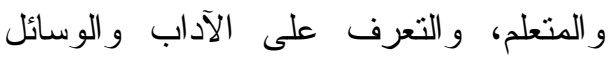

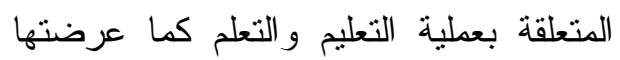
القصة، واستخدم الباحث المنهج الوصفي في دراسته، ونوصل إلى مجموعة من النتائج، من أبرزها: الاستعانة بالصحبة الأمينة

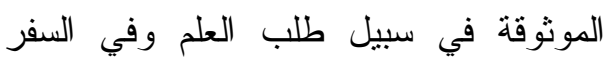
لأجله، و الصبر على تحمل المشاق وتجاوز
رغم قصرها آياتها إلا أنها حافلة بالقيم التربوية والاجتماعية التي يعود نفعها على إلى الاتها

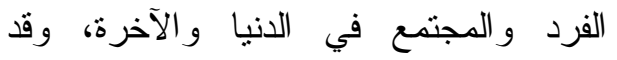

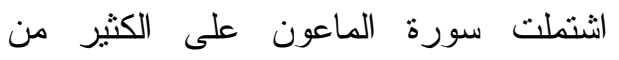
المضامين و النطبيقات التزبوية في الجانب العقدي و التعبدي و الاجتماعي، إن التصديق بيوم الدين يجعل المسلم حريصاً على أداء الشعائر التعبدية ويزيد من وحدة المسلمين

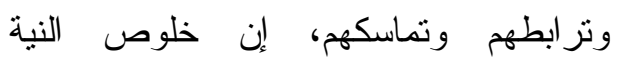
وتوجهها إلى اله سبحانه وتعالى في كل عمل ونل

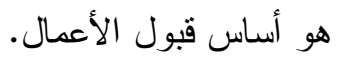
در اسة(الدبيسي، آس \& ( ) و التي هدفت إلى بيان المضامين التزبوية المستتبطة من سورة القلم في الجانب العقدي، و التعبدي، و الأخلاقي، والاجتماعي، ثم نوضيح أبرز الأساليب التربوية المستتبطة منها. واستخدم الباحث المنهج الوصفي والمنهج الاستتباطي، وكان ونان

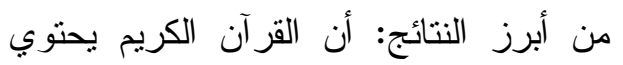
على منهج عظيم للتربية الصحيحة التي في

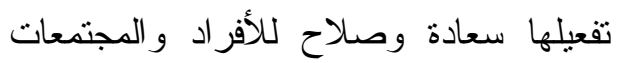
في الدنيا و الآخرة، وأنها احتوت على العديد

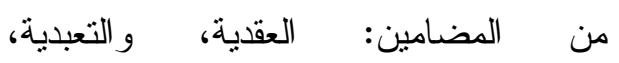
و الأخلاقية، و الاجتماعية، وبعض الاساليب

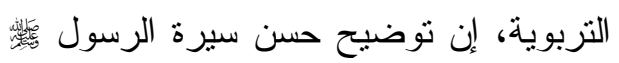

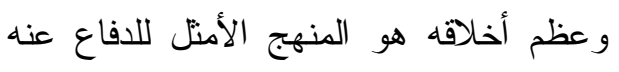

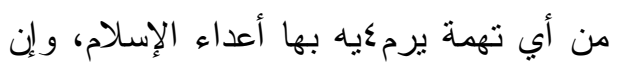

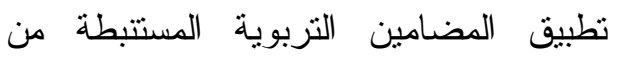


الصعوبات مهما عظمت، مكاثفة المعلم بما دراسة (الزايدي، إس؟ () التي هدفت إلى بيان

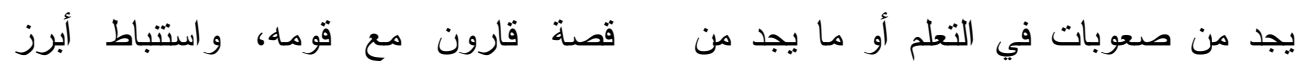

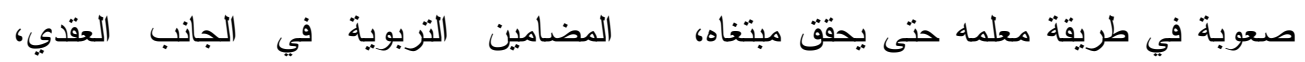

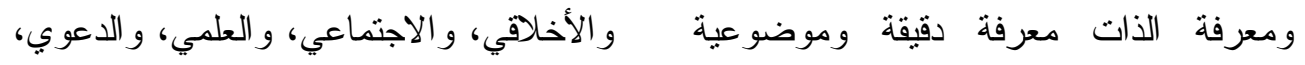

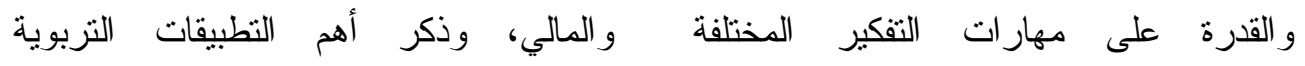

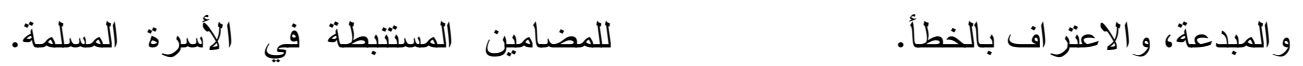

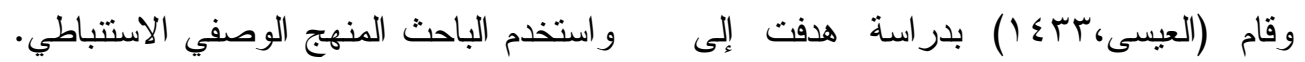

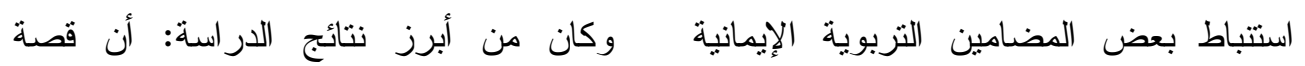

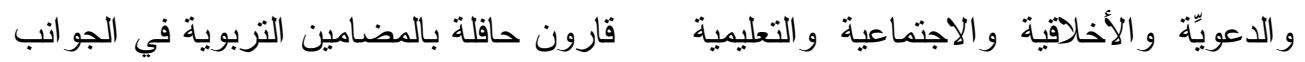

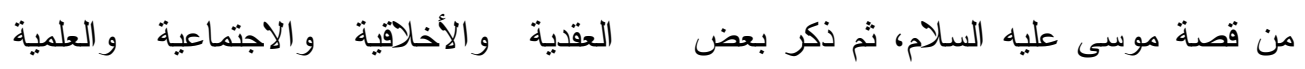

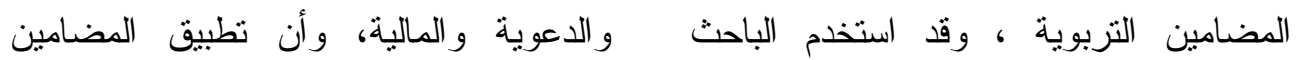

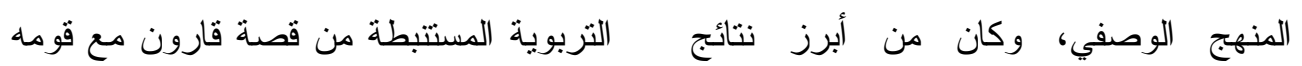

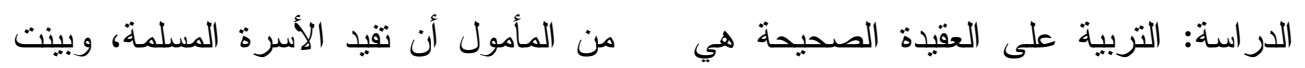

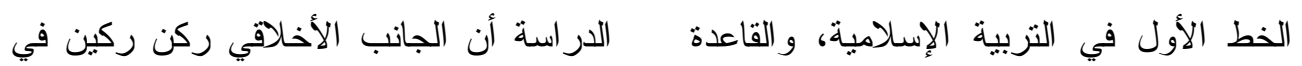

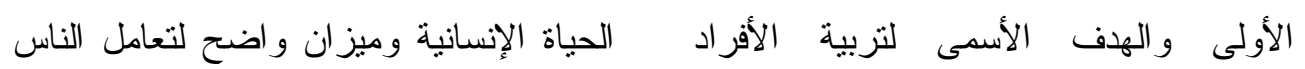
و الجماعات، وأن الأخذ بالأسباب طاعة لله فيما بينه،، وبينت أهمية التكافل الاجتماعي الإنية عزوجل وتوكل عليه، ولكن ليست هي بين الناس، حيث إنه يسد الفجوة المعيشية عند الفاعلة، و إنما الفاعل الحقيقي هو اله جل الفقر اء، وينشر المحبة و الوئام.

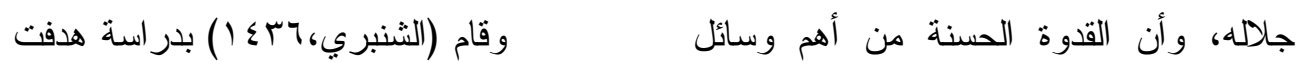
إلى إيضاح مكانة سورة الحاقة في القرآن

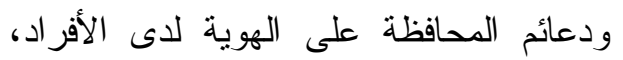

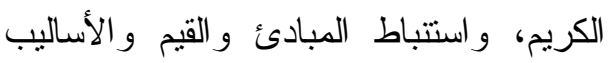

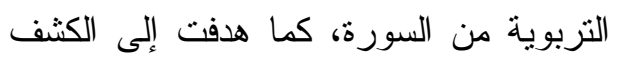
عن أهم التطبيقات التربوية للمبادئ المستتبطة من السورة في الواقع المعاصر ـ و واستخدمت الهن

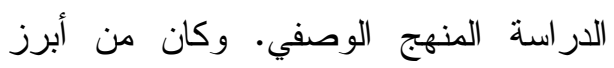

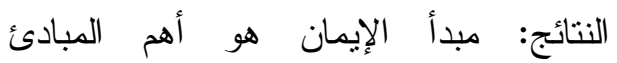
وتحقيق الثبات في نفوسهم، وتتمية روح المسؤولية و الإبداع و الطموح، و أن الأديان

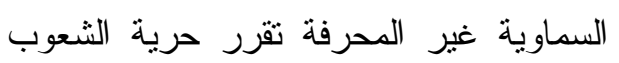
وحقها في التخلص من استعباد الأقوياء، وأن الله عزوجل بحفظ الأبناء إكراماً لآبائهم المستتبطة من سورة الحاقة، حيث إنه هو 
اتفقت معها في استخدام المنهج الوصفي، كما

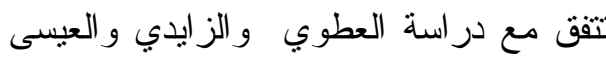

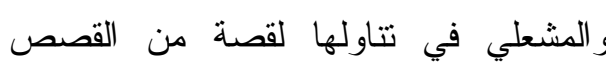
الواردة في كتاب الله سبحانه وتعالى حيث تتاول العطوي و العيسى قصة موسى عليه

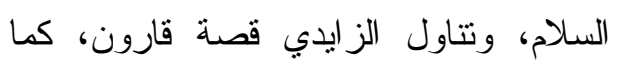

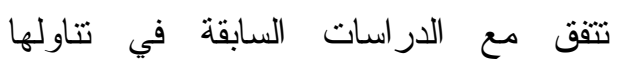
للتطبيقات التربوية للمضامين.

وتختلف الدراسة الحالية عن الدراسات السابقة في نتاولها لقصة ابني آدم عليه السلام الواردة في القرآن الكريم من سورة المائدة،

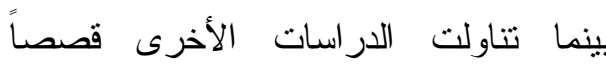
أخرى، وسوراً أخرى من كتاب الله جلَّ لَّلَ شأنه، كما تختلف عن الدراسات السابقة في

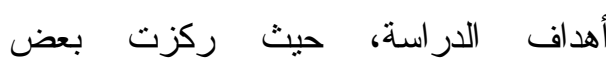
الدراسات على الجانب التعليمي منل دراسة العطوي و الز ايدي.

وقد استفادت الدراسة الحالية من الدراسات

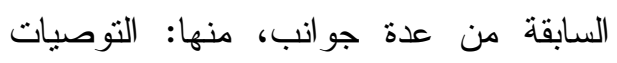

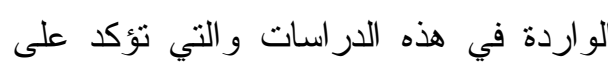
أهمية تتاول المضامين التربوية المستتبطة من لهن لهن

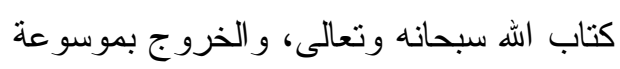
في ذلك، كما استفادت في المنهجية العلمية في تناول المضامين التزبوية في كتاب الها

$$
\text { سبحانه وتعالى. }
$$

وتميزت الدراسة الحالية بتناولها لقصة ابني

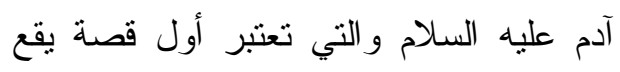

أساس العقبدة الإسلامية، وحياة الإنسان

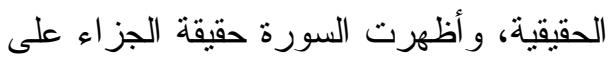
العمل، فمن أحسن جوزي خيراً، ومن أساء فجزاؤه عذاب أليم، تتزيه القرآن عن الثنعر و الكهانة، و الحث على تعظيمه و إعلاء شأنه.

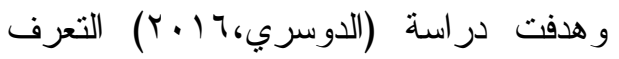
على المضامين التربوية في سورة الكافرون، وتحديد وسائل تعزيز تلك المضامين لدى فئ لـوني

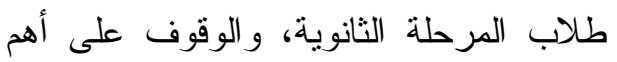
الصعوبات التي تعيق تعزيز تلك المضامين

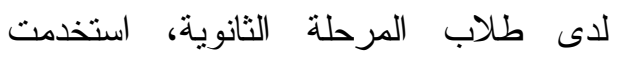
الدراسة المنهج الاستتباطي، وتوصل الباحث إلى تضمن الآيات لمجموعة من المضامين التربوية، منها: الحوار مع المخالف، حرية الائل

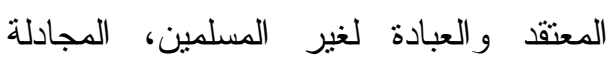
بالحسنى واحترام الآخر وإن كان مخالفاً في

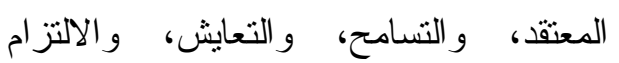
بالثو ابت وعدم المساومة عليها.

\section{التعليق على الدراسات السابقة :}

من خلال استعر اض الدراسات السابقة ، فإنَّ

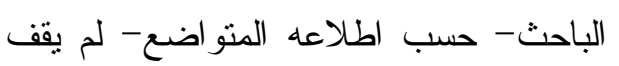
على دراسة تنتاول المضامين التربوية المسنتبطة من قصة ابني آدم عليه السلام الو اردة في القر آن الكريم.

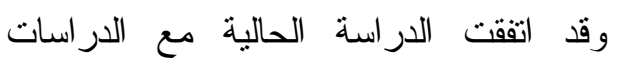
السابقة في دراستها للمضامين التربوية الواردة في كتاب الله سبحانه وتعالى، كما 


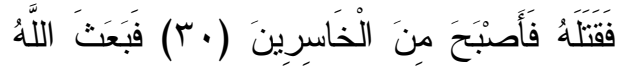

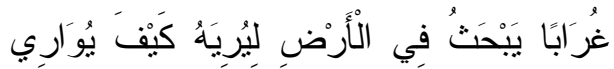

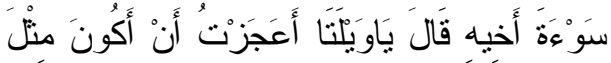

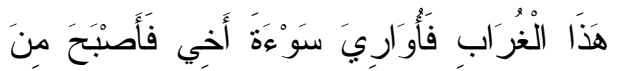

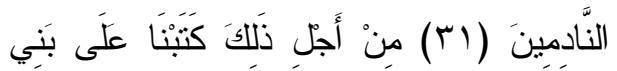

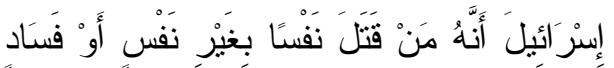

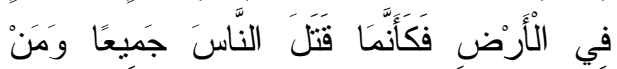

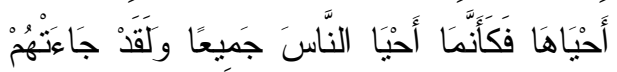

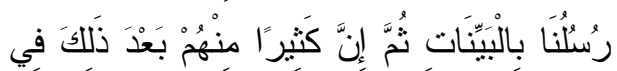

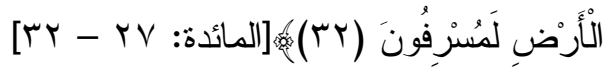

التعريف بقصة ابني آدم عليه السلام:

ذكر علماء التفسير عند تفسيرهم لهذه الآيات العطرات مجموعة من الأحاديث لهيث والأثار والأخبار عن قصة ابني آدم عليه السلام ، إلا أنها محل خلاف عند المحدثين و المفسرين في تصحيحها وتضعيفها. ومن ذلك: ما" ذكره غير واحد من السلف

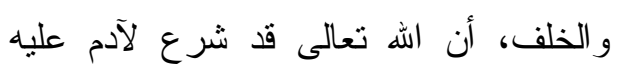

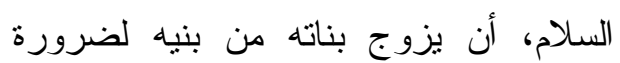

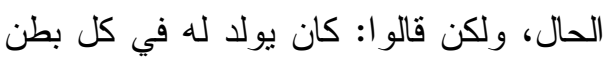

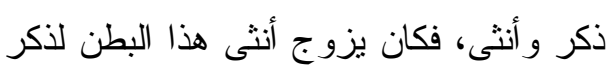

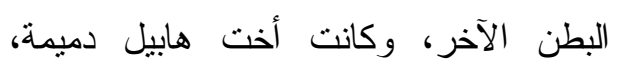

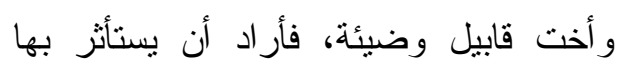

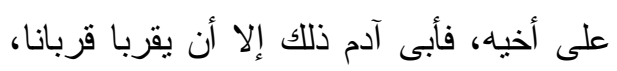

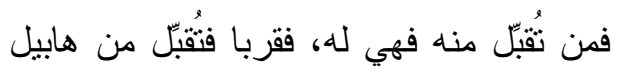

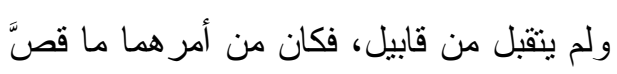

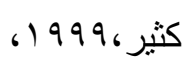

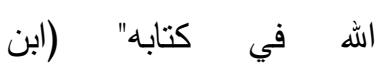

فيها القتل والحسد بين أخوين ولجانب يتططق

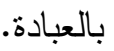
منهج الدراسة : - مانة

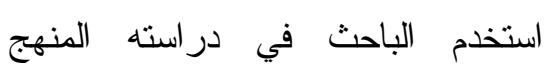
الوصفي الاستتباطي ، حيث إنه هو المناسب مع هذه الدراسة ، ويحقق أهدافها، والمنهج النها

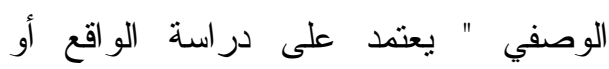
الظاهرة كما توجد في الواقع ويهتم بوصفها

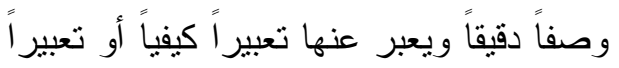

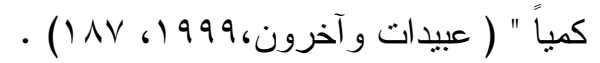
وسيقوم الباحث باستتباط المضامين

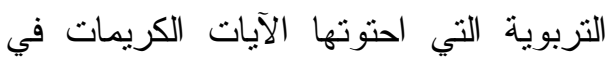

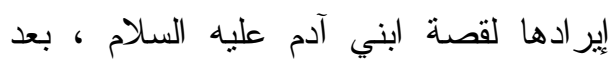
الرجوع إلى التفاسير العلمية المعتمدة في ذلك التكان

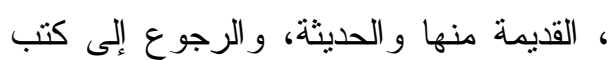

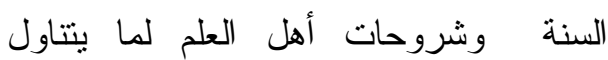
موضوع الدر اسة.

النص القرآني الكريم لقصة ابني آدم عليه السلام :

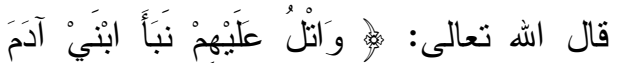

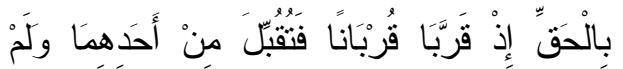

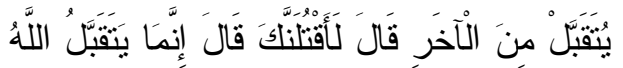

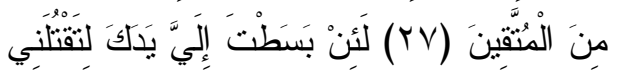

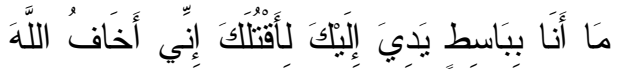

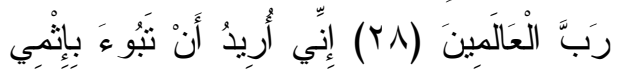

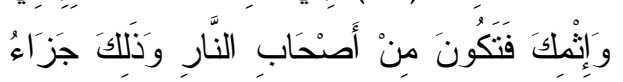

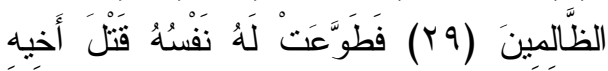


r/r/r).وذُكر غيرها من التفاصيل التي لم قربانا فتقبل من أحدهما ولم يتقبل من الآخر

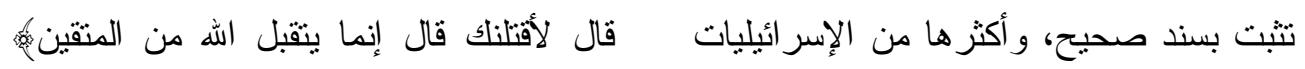
فالسياق بقتضي أنه إنما غضب إنما بنغل عليه وحسده التي لا تخالف شر عنا.

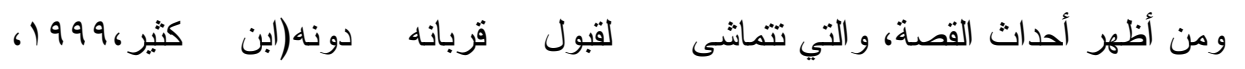

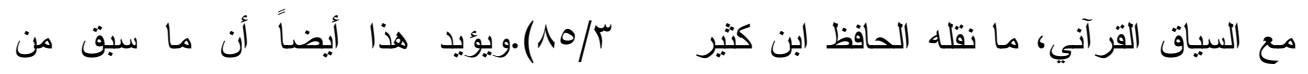

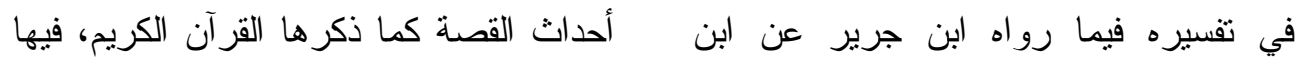

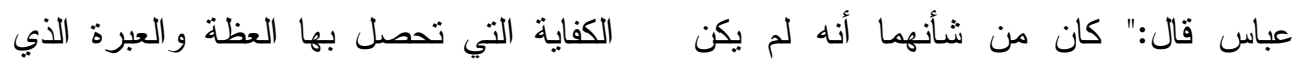

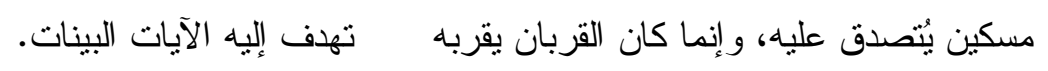
وفي تمام القصة "قيل: إنه لما قتل أخاه

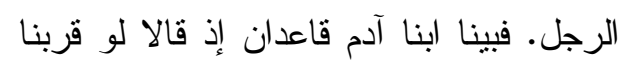

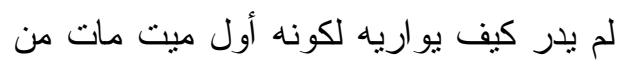
بني آدم، فبعث الله غر ابين أخوين فاقتتلا، فقتل أحدهما صاحبه فحفر له، ثم حثا عليه، فلما رآه قابيل قال يا ويلتى أعجزت أن أكون

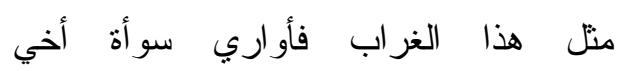

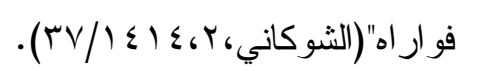
قربانا، وكان الرجل إذا قرب قربانا فرضيه الله، أرسل إليه نارا فتأكله، و وإن لم يكن رضيه الله خبت النار، فقربا قربانا، وكان

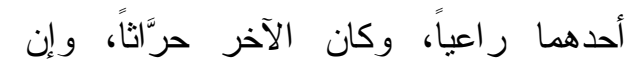
صاحب الغنم قرَّب خير غنما وأنه وأسمنها،

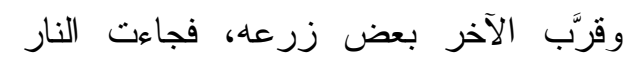

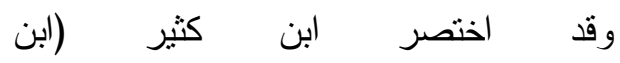

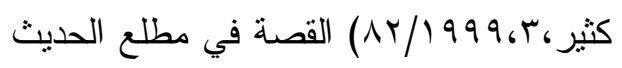
عن الآيات، و أنها تتحدث عن " خبر ابني آدم

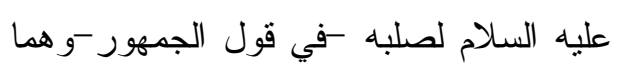

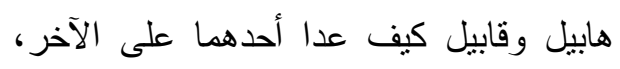

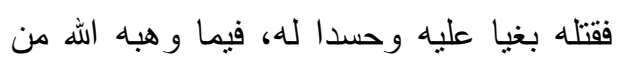
النعمة وتقبل القربان الذي أخلص فيه لله عز

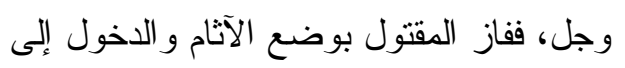
الجنة، وخاب القاتل ورجع بالصفقة الخاسرة

$$
\text { في الدنيا و الآخرة). }
$$

هذه أبرز ملامح القصة لابني آدم عليه

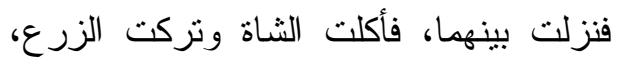
و إن ابن آدم قال لأخيه: أتمشي في الناس وقد فئد

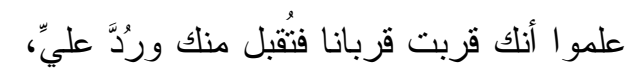
فلا و اله لا ينظر الناس إليك و إليّ و أنت خير

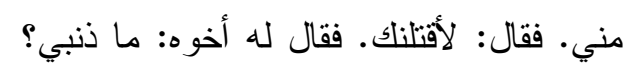

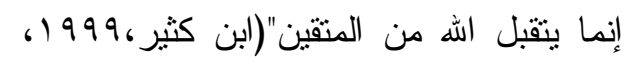
. ( $1 \varepsilon / r$ وقد أيَّد الحافظ ابن كثير هذا الأثر لموافقته

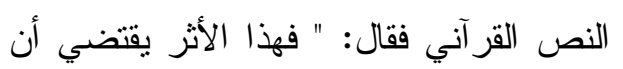
تقريب القربان كان لا عن سبب، ولا عن

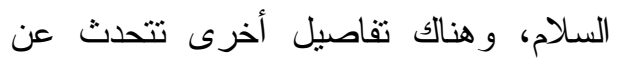

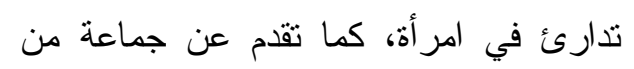

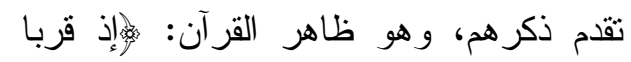


وجاء كذلك في بيان مناسبة هذه الآيات لما قبلها، والتي ذكر الله فيها بعض أحوال

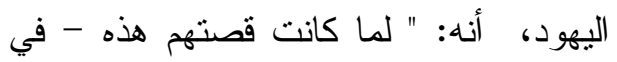
أمرهم بالدخول إلى الأرض المقدسة لما فيها

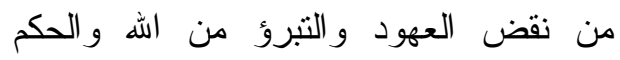
عليهح بالفسق والتعذيب - ناقضة لما ادعاه البهود من البنوة، كان ذلك كافياً في إبطال

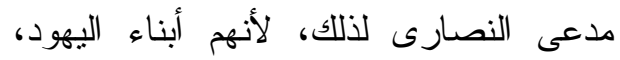

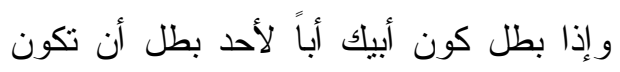
أنت ابنه، لما كان ذلك كذللك ناسب أن تعقب بقصة ابني آدم عليه السلام لما يُذكر، فقال

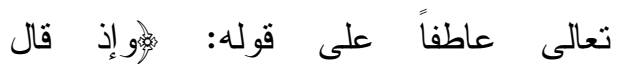

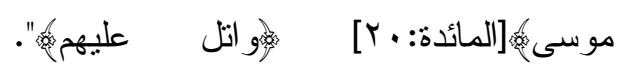

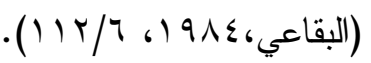

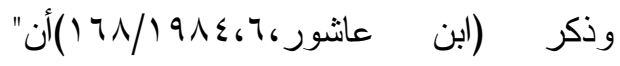
المناسبة بينها وبين القصة التي قبلها مناسبة تماتل ومناسبة تضاد. فأما التماتل: فإن في كلتيهما عدم الرضا بما حكم الله تعالى؛ فإن

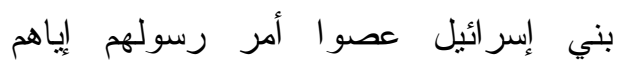
بالدخول إلى الأرض المقدسة، و أحد ابني آدم

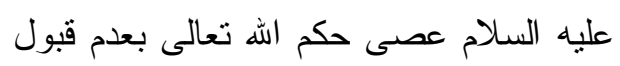
قربانه لأنه لم يكن من المتقين. وفي كلتيهما

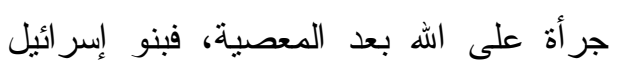
قالوا: فاذهب أنت وربك، وابن آدم قال:

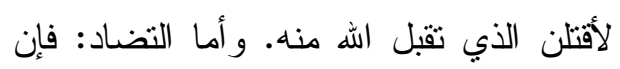

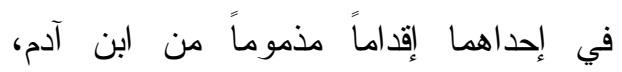

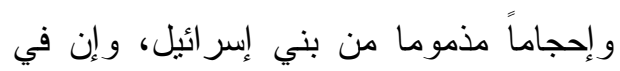

طريقة القتل، وغيرها مما لا يثبت بدليل قطعي، وما تم ذكره فيه الكفاية في الاستفادة من مضامينها. مناسبة الآيات لما قبلها:

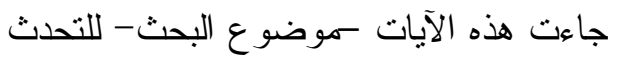

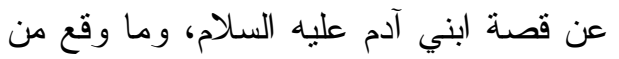

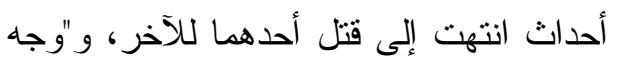
اتصال هذه الآية بما قبلها، التنبيه من الله تعالى على أن ظلم اليهود، ونقضهم المو اثثيق

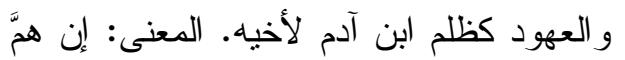
هؤلاء اليهود بالفتلك بك يا محمد، فقد قتلوا

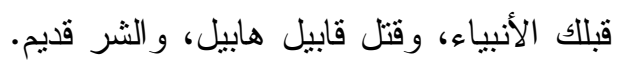
أب ذكرهم هذه القصة فهي قصة صدق، لا لألاءل كالأحاديث الموضوعة، وفي ذلك تنكيت لمن خالف الإسلام، وتنسلية للنبي صلى الله

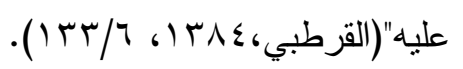
كما "أورد الله تعالى هذه القصة لبيان نأثير

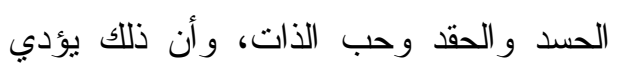
إلى المخاطر و المهالك و القبائح، فقضى على وان دلى ولى ولى رابطة الأخوة التي تجمع بين الأخوين، وأدى لئى إلى سفك الدماء. وأمنلة ذلك كثيرة، فبعد أن ذكر تعالى حسد اليهود للنبي صلّى الله عليه

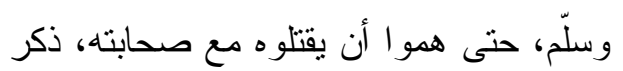

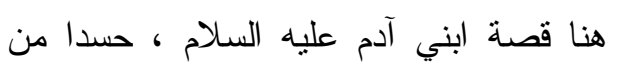

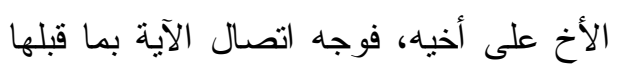

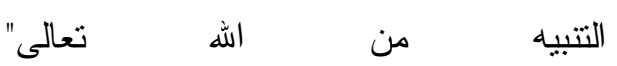

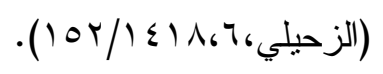


إحداهما اتفاق أخوين هما موسى وأخوه على حكمة ذللك، فجاءت هذه القصة في هذا المقام،

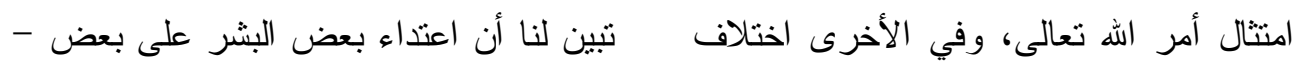

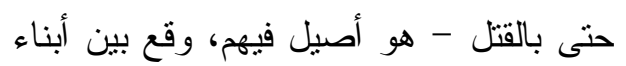
أخوين بالصلاح و الفساد".

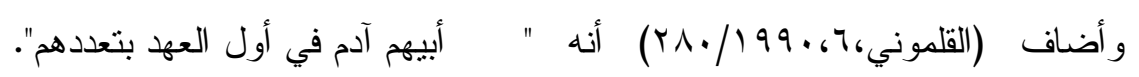

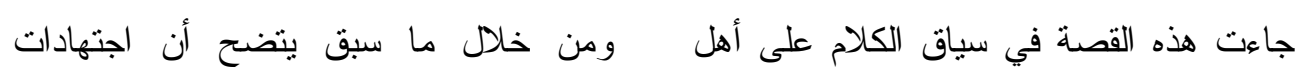

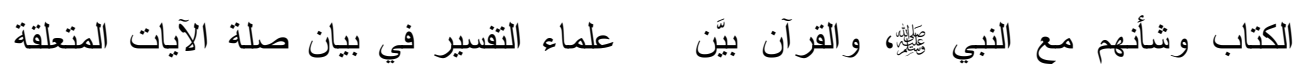

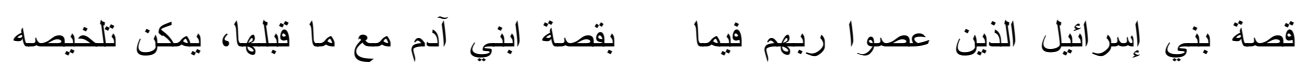
كلفهز من قتال الجبارين، وبين ما شرعه الله

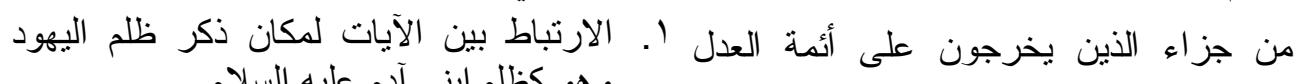

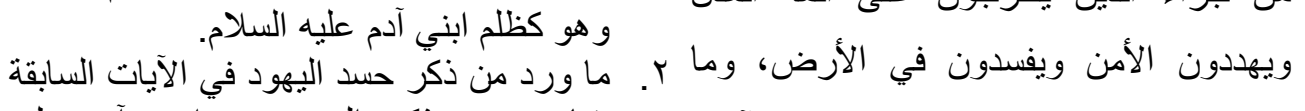

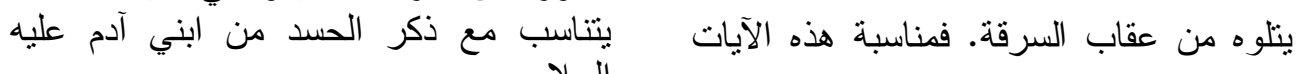

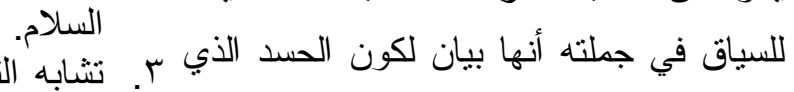

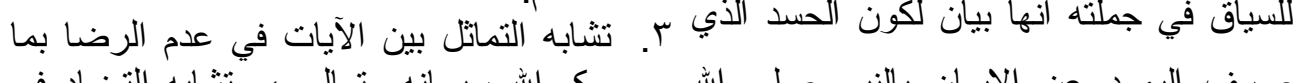

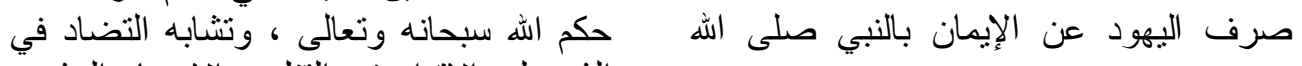

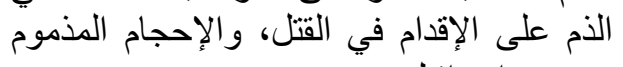

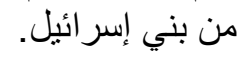

\section{تفسير الآيات:}

جاءت الآيات التي تتحدث عن قصة ابني آدم عليه السلام وما يتعلق بها في سورة الإت لئات

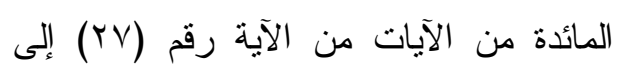

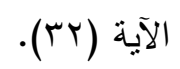
و ابتدأ سبحانه وتعالى الآيات بالأمر في

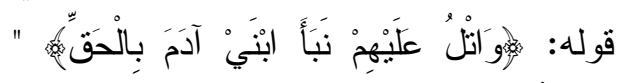

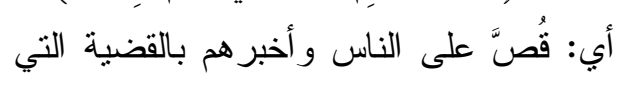
جرت على ابني آدم بالحق، تلاوة يعتبر بها

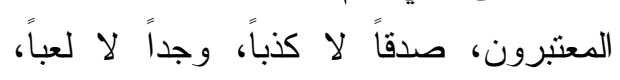

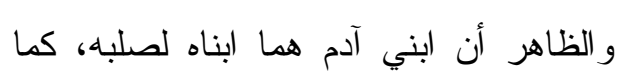

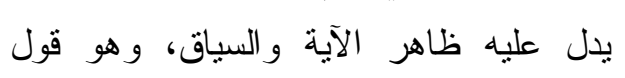
المفسرين" عليه وسلم وحملهم على عداوته عريقا في بلاني الآدميين وأثزراً من آثار سلفهم، كان لهؤل ألهاء القوم منه النصيب الأوفر، ويتضمن تشلية النبي صلى الله عليه وسلم و المؤمنين و إزالة استغر ابهم إعر اض هذا الثعب عن الإسلام

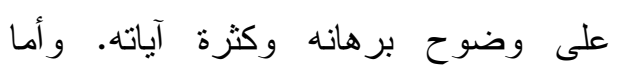
مناسبتها لما قبلها وما بعدها مباشرة؛ فهو

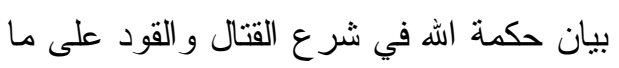
شدد فيه من تحريم قتل النفس، ذلك أنه لها كان القتال بين الأمم وقتل الحكومات للأفر اد، أو تعذيبهم بقطع الأطر ف، كل ذلك قبيحا في

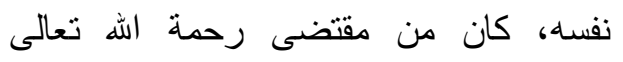

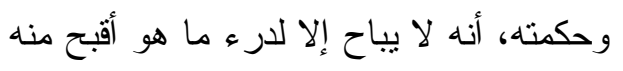

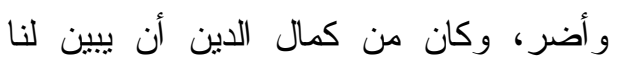


وظاهر الآية الكريمة أنه " أخرج كل

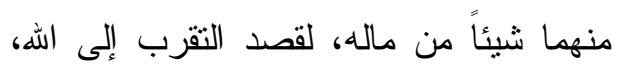

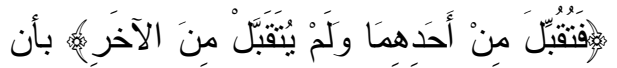
علم ذلك بخبر من السماء، أو بالعادة السابقة

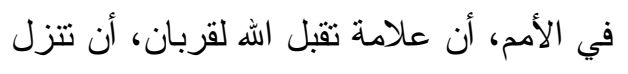
نار من السماء فتحرقه" (السعدي، ......

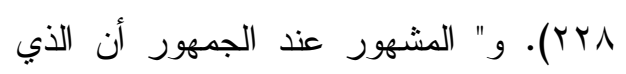
قرب الثاة هو هابيل، وأن الذي قرب الطعام

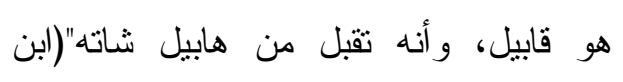

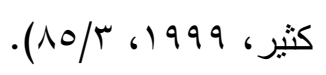

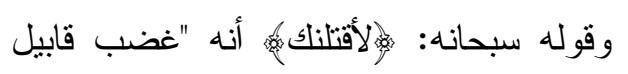

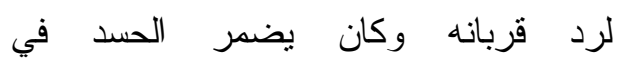

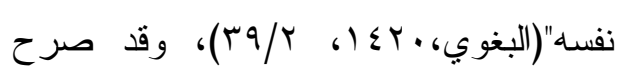
غير واحد من المفسرين أن الحسد هو الذي ولي

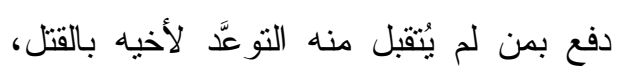

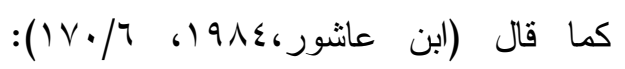
"و إنما حمله على قتل أخيه حسده على مزيّة

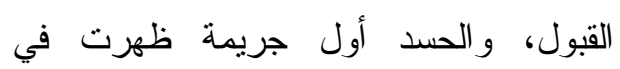
الأرض" - الفول وتكثف الآيات العطر ات عن الحالة التي وقع فيها من لم يُتقبل منه من الحسد الذي ساقه

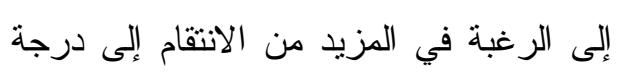

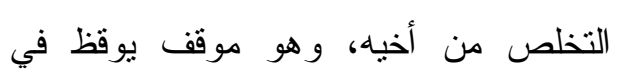

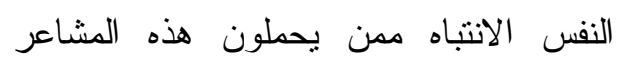
السلبية التي لا تتو افق مع مبدأ الرضا بمان لهان كتب الله سبحانه وتتعالى.

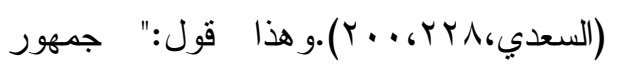

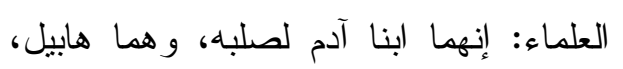
وقابيل"(الشنقيطي، 1990، / / / / النه).

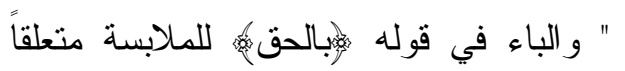

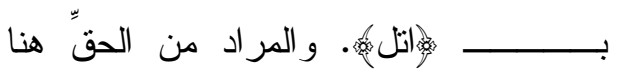

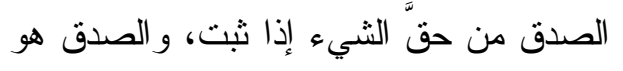

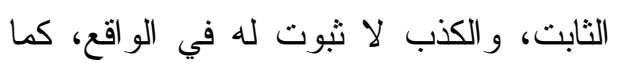

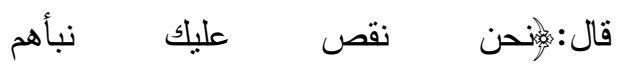

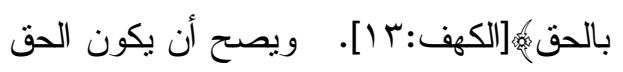
ضد الباطل وهو الجدُ غير الهزل، أي اتل

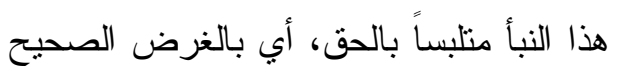

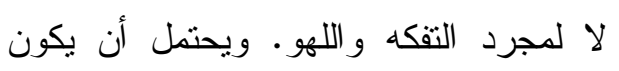

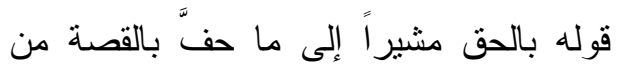
زيادات زادها أهل القصص من بني إسرائيل

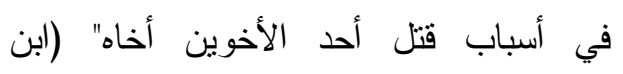
عانشور، 191917، 179/7). ومن هنا تظهر أهمية القصص التي ترد في

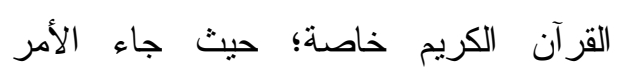
بذكر ها، وغير ها من القصص النافعة عامَّة، على أن تكون مصحوبة بصفة الصدق التي نصت عليها الآيات.

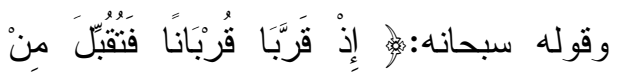

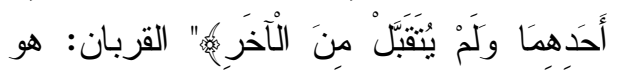
البر الذي يُقصد به القرب من رحمة الله،

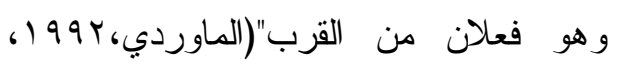
.$(r / T V$ 


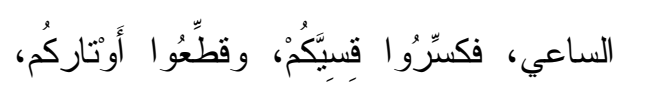

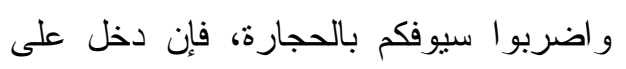

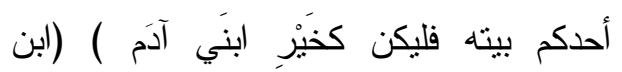

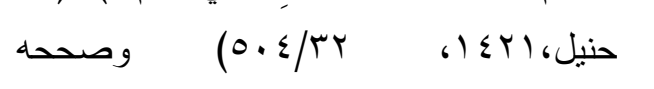

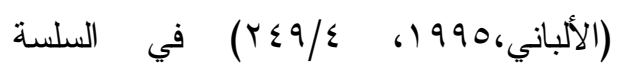

الصحيحة . الأب،

وتُظهر الآيات الكريمات فضل الخوف من اله سبحانه وتعالى، و الحلم على السفهاء، ومقابلة

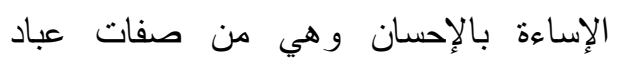
الرحمن، كما نتحدث الآيات عن المقابلة بالإحسان لأشنع الإساءات بالفعل، فما كان الإب بالقول فهو من باب أولى في مقابلته بالصبر و والإحسان.

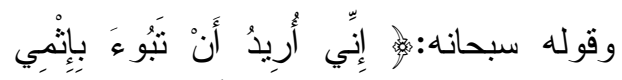

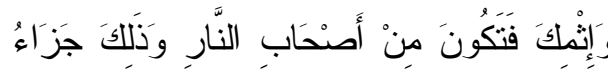

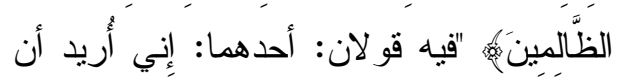

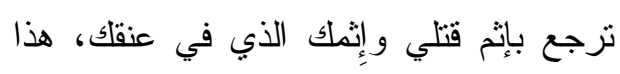
قول ابن مسعود، ورابن عباس. و ومجاهد،

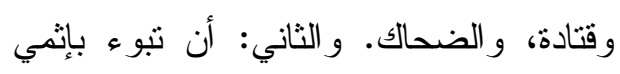

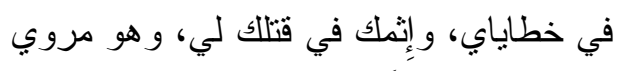

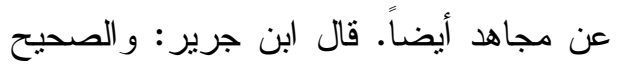
عن مجاهد القول الأول. وقد روى البنال درير : ولاري

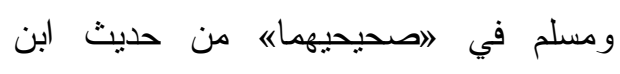

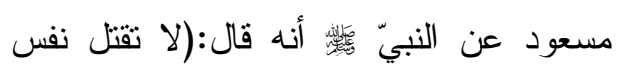

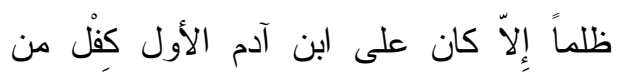

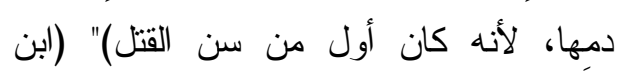

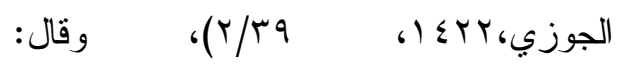

ثم جاء الرد من ابن آدم المحسن، والذي

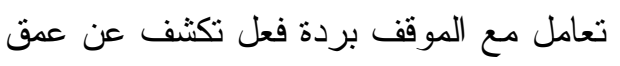

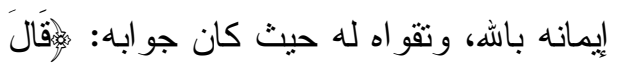

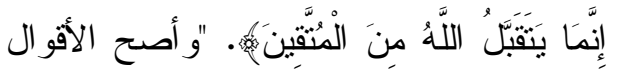
في تفسير المتقين هنا، أي: المتقين لله في ذلك الكي العمل، بأن يكون عملهم خالصا لوجه الله، متبعين فيه لسنة رسول اله صلى الهُ عليه

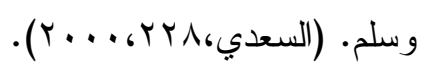

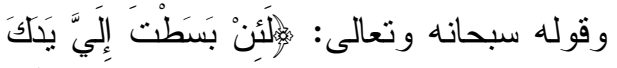

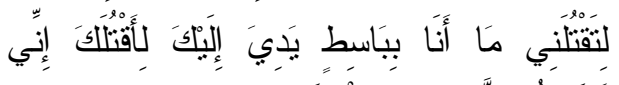

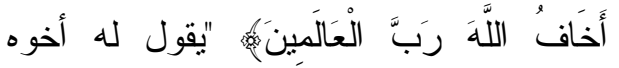

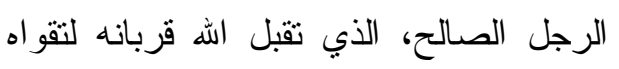

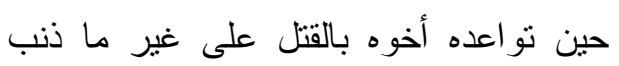

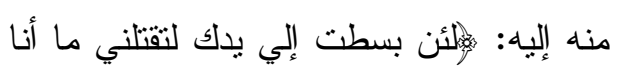

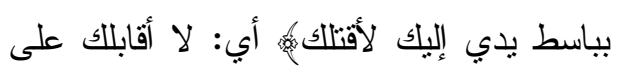

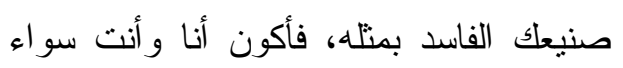

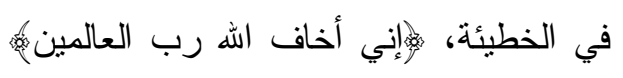

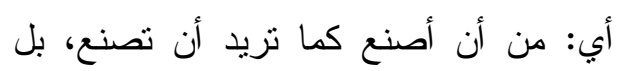

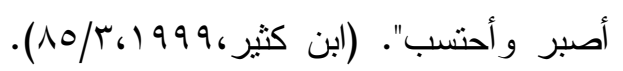
وذلك لعظيم ذنب القتل وخطره على المؤمن.

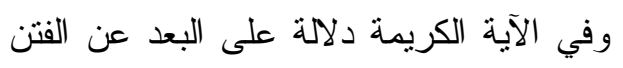

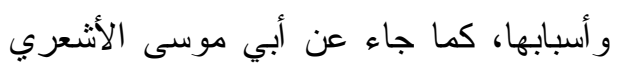
قال: قال رسول اللهاء فتتاً كقطع الليل المظلم، بصبح الرجل فيها

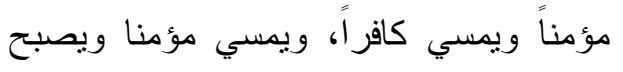
كافراً، القاعد فيها خير من القائم، و القائم فيها خير من المانشي، والماشي فيها خير من المن 
رأى قابيل ذلك، قال: يا ويلتا كلمة تحسر، فقيل لما رأى الدفن من الغراب أنه أكبر علماً

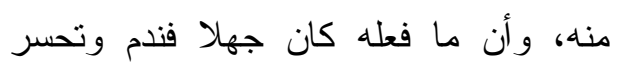

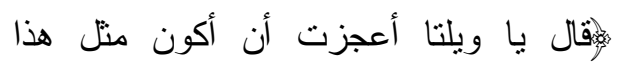
الغراب فأو اري سوأة أخيمه أي: جيفته، وقيل: عورته لأنه قد سلب ثيابه، وفأفأصبح

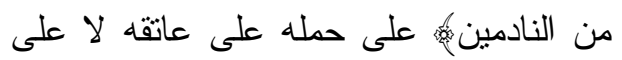

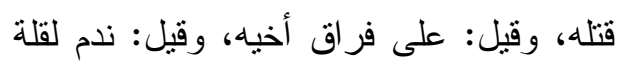

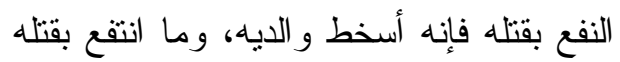
شيئًا ولم يكن ندمه على فإنه القتل وركوب وابها

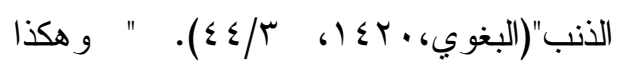
الندامة عاقبة

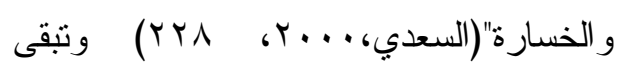
الآية الكريمة على عمومها في هذا المعنى.

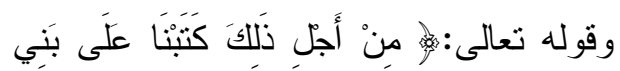

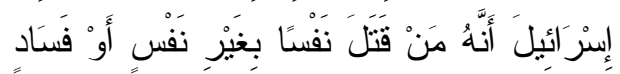

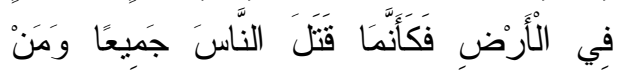

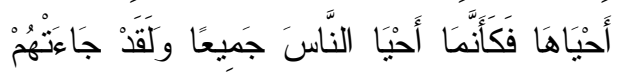

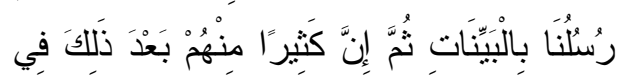

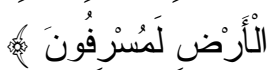

و هذه الآية الكريمة فيها مجموعة من المعاني،

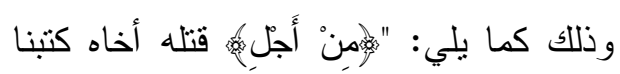

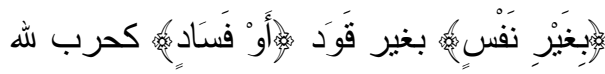

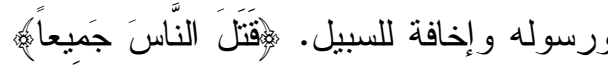

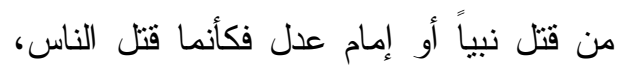
ومن شدّ على يد نبي أو إمام عدل فكأنما أحيا الناس قاله ابن عباس - رضي لدي اله تعالى

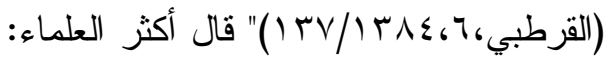
إن المعنى، نرجع بإثم قتلي و إثمك الذي عملته قبل قتلي. قال الثعلبي: هذا قول عامة أكثر المفسرين".

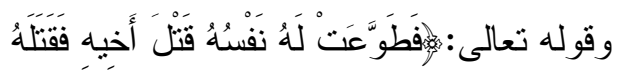

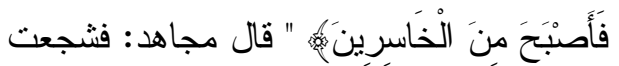
له نفسه، وقال قتادة: زينت له له نفسه، وقيل:

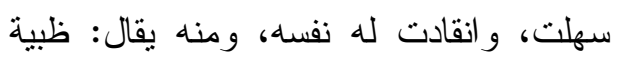
أطاعت لها أصول الشجرة، أي: انقادت ولهات

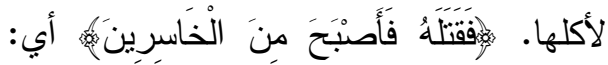
خسر بقتله الدنيا والآخرة، أما الدنيا: لأنه الأله أسخط و الديه، وبقي بلا أخ، و وأما الآخرة:

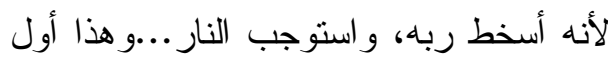

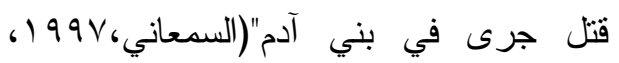
$(r) / r$

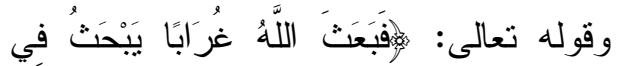

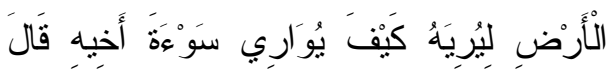

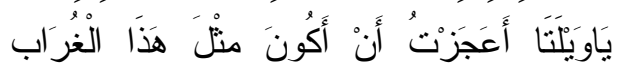

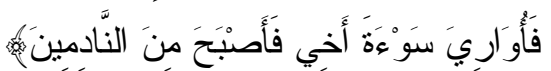
كانت جريمة القتل هذه هي أول واقعة قتل

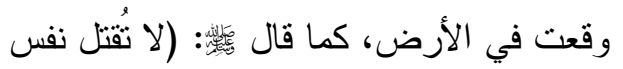

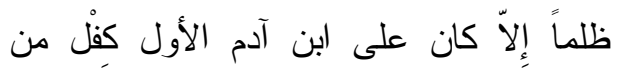

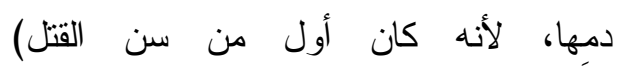

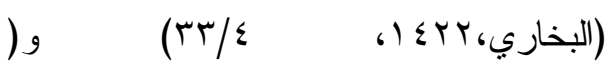

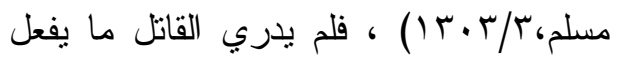

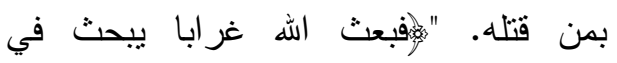
الأرض ليريه كيف يواري سوأة أخيهم. فلما 
وقد اثتملت قصة ابني آدم عليه السلام على

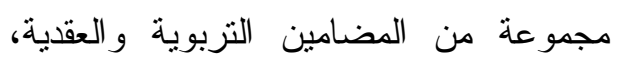
منها ما يلي:

المضمون الاول : الخوف من الله سبحانه وتعالى :

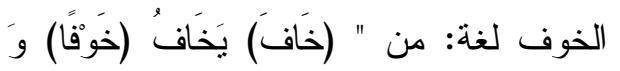

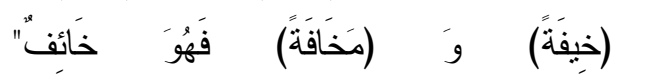

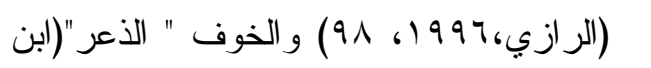

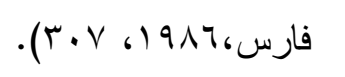

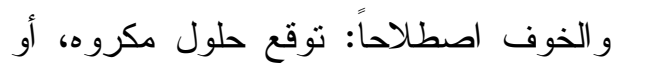

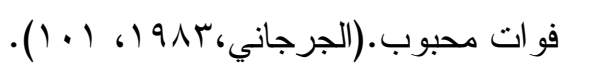
وقد ذكرت الآيات في قصة ابني آدم عليه السلام مضمون الخوف من الله صراحة، دلالة على وجود هذا المعنى في نفوس أبناء آدم، واختلف القيام به، وامتثالهم لله فيما لهاء بينهم. و الخوف من الله سبحانه وتعالى هو صفة مدح نتربى عليه النفوس ، وقد أثثى اله له

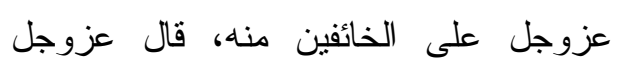

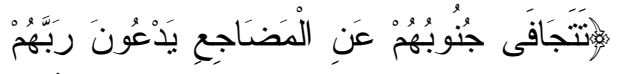

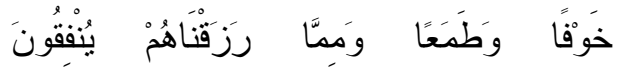

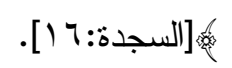

ويكفي الخوف من اله شرفاً ومكانةً أن

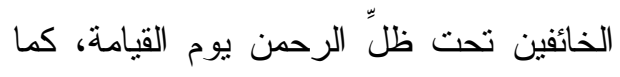

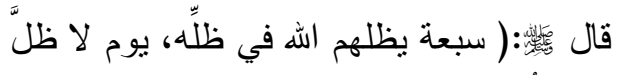

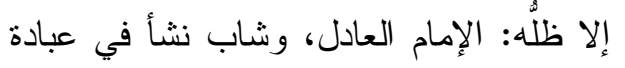
ربه، ورجل قلبه معلق في المساجد، ورجلان تحابا في الله اجتمعا عليه وتفرقا عليه، ورجل فل ولئ
عنهما -، أو كأنما قتل الناس عند المقتول. ومن استتقذها من هلكة فكأنما أحيا الناس عند الندان

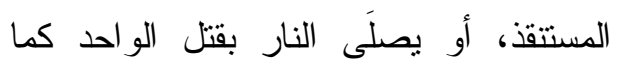
يصلاها بقتل الكل، وإن سلّم من قتلها فقد سلم

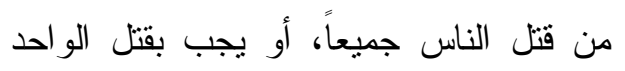
من القصاص ما يجب بقتل الكل. ومن أحيا

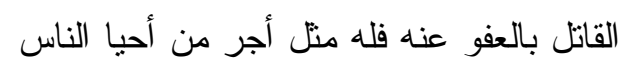

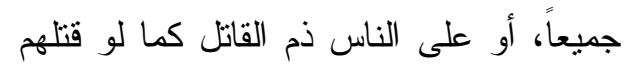

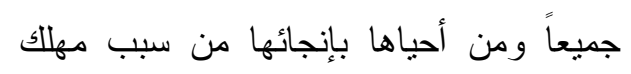

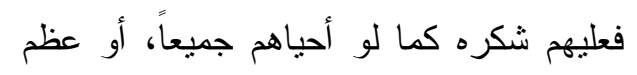

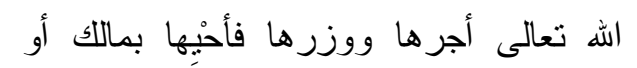

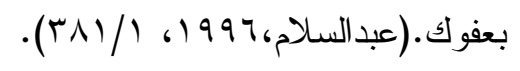
المضامين التتبوية المستنبطة من قصة ابني آدم عليه

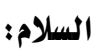
أولاً : المضاميز التزبوية المستنبطة في الجانب العقدي والتعبدي:

تعتبر التربية العقدية هي الأساس في جميع

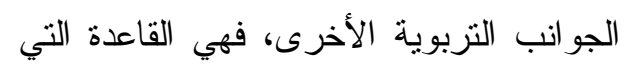

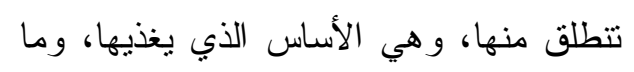
تحركت النفوس نحو استقامة السلوك إلا بقوة

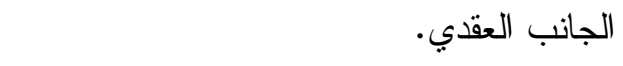
ويمنل الجانب التعبدي ميداناً من ميادين

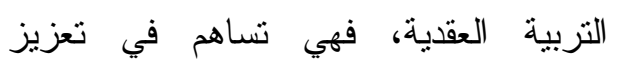
متنقدات العبد من التوجه إلى الله سبحانه

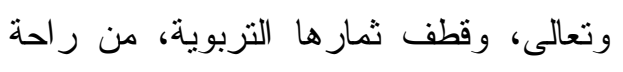
النفس، واستقرار القلب، وثبات التطبيق. 
و المحاسبة لها عدة معان، و المراد بها هنا

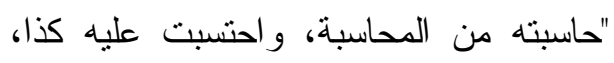

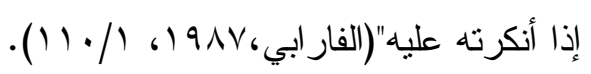
ومحاسبة النفس اصطلاحاً هي: أن يتصفّح الإنسان في ليله ما صدر من أفعال نهاره فإن

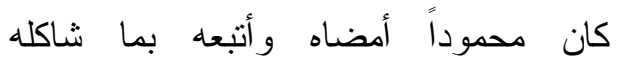
وضاهاه، و إن كان مذموماً استنركه إن أمكن،

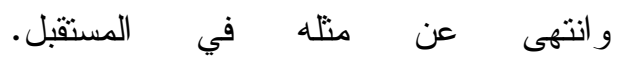

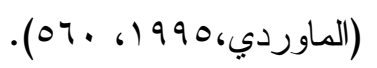

والآيات التي تحدثت عن قصة ابني آدم عليه السلام تحدثت عن سلوك النفس البشرية التي تمنلت في نفس القاتل عندما طوعت له نفسه قتل أخيه، وكيف استجاب لها، قال عزوجل:

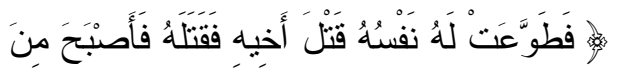

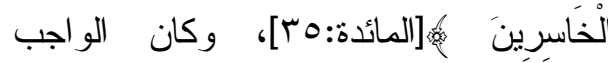
الانتباه لهذه النفس، ومحاسبتها، وأن لديها

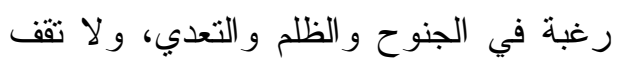
إلا بمحاسبتها عن غيها، قبل وقوع الخطأ. "وقد دل على وجوب محاسبة النفس قوله

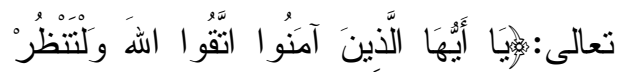

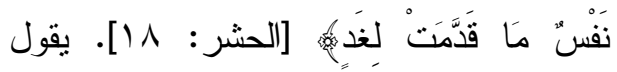
تعالى: لينظر أحدكم ما قدم ليوم القيامة من لألمان

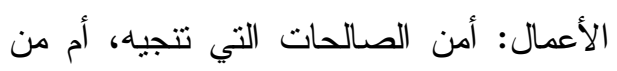

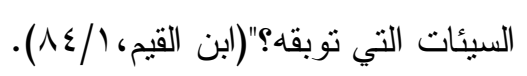

و "أجمع العلماء على وجوب محاسبة النفوس فيما سلف في الأعمال وفيما بستقبل منها وجاه فالكيس من دان نفسه وعمل لما بعد الموت
طلبته امر أة ذات منصب وجمال، فقال: إني أخاف الله، ورجل تصدق، أخفى حتى لا تعلم شماله ما تتفق يمينه، ورجل ذكر الله خالياً ففاضت

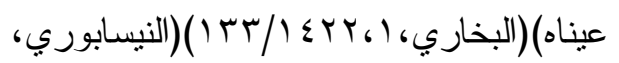
$.(\mathrm{V}) 0 / \mathrm{r}$ والخوف سبب للنجاة من عذاب الله يوم

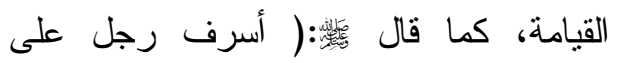
نفسه، فلما حضره الموت أوصى بنيه فقال:

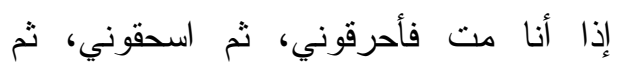

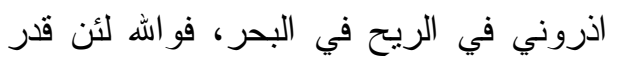
علي ربي ليعذبني عذاباً ما عذبه به أحداً، قال

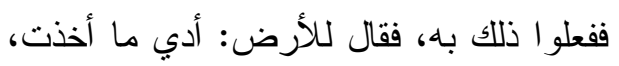

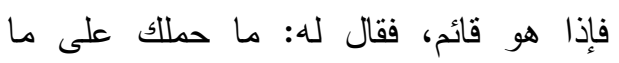

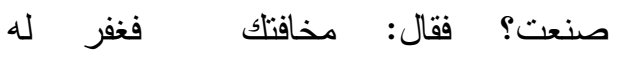

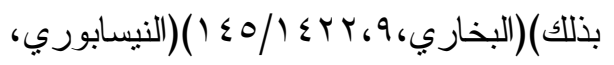
. (r) ) / 1 s و الخوف من الله هو عقيدة تتربع في قلب المؤمن، يعظم الله في قلبه، فيخاف من عذابه، كما يبقيه الخوف حذراً من الوقوع في في فئل

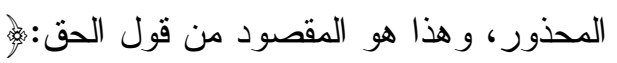

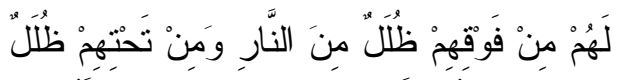

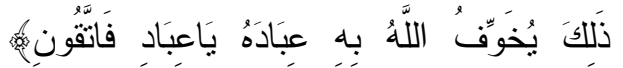

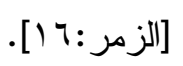
المضمون الثاني : محاسبة النفس وا لحذر منها : 
و التقرب إلى اله يكون بالعبادة التي أرسل الله الرسل لتحقيقها، كما قال سبحانه وتعالى:

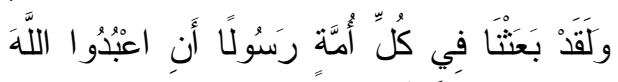

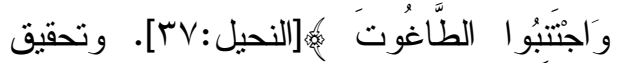
العبادة هو الأصل في خلق اله للناس، قال

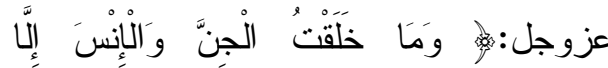

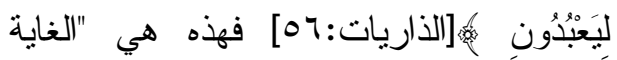
التي خلق الله الجن والإنس لها، وبعث جميع الرسل يدعون إليها، وهي عبادنه، المتضمنة

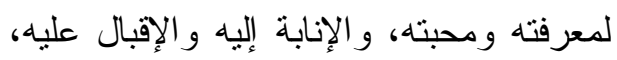

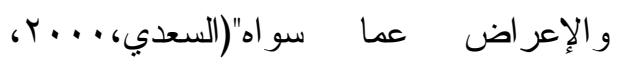

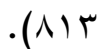
و الثريعة الإسلامية أمرت بالعبادة على الحال الذي جاء في كتاب اله عزوجل، وسنة النبي

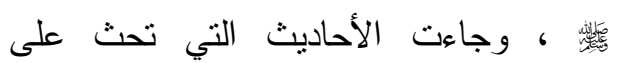
التقرب إلى اله عزوجل، و لا سيما الفرائض

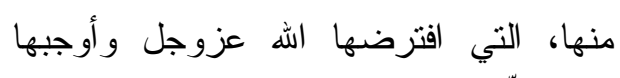

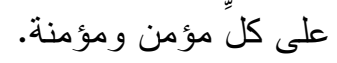
ومما جاء في فضل التقرب إلى الله عزوجل ومؤه الحديث القدسي، وفيه أن النبي فئي الله تعالى: (من عادى لي ولياً فقد آذنته بالحرب، وما تقرب إلي عبدي بشيء أحبَّ

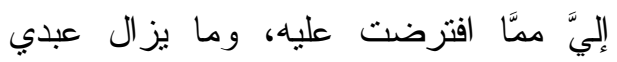
يتقرب إلي بالنو افل حتى أحبه، فإذا أحبيته:

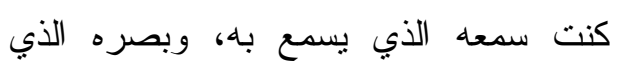
ييصر به، ويده التي يبطش بها، ورجله التي بلي

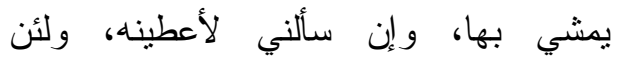

و العاجز من أتبع نفسه هو اها وتمنى على الله

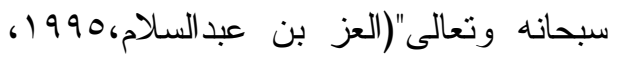
.$(\mathrm{V} / \mathrm{M}$ فينبغي على المؤمن أن يقى يقظاً لنفسه، وأن

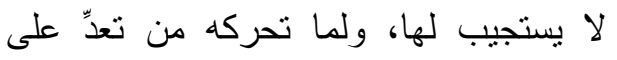

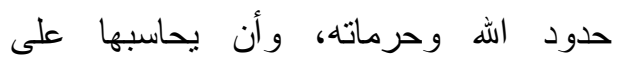
رغباتها المخالفة لشرع اله عزوجل، قبل أن وحن يقع الخطأ الذي يتبعه الندم و الحسرة في الدنيا و الآخرة، ويسعى إلى تربيتها على الانقياد

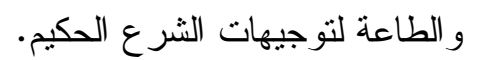
المضمون الثالث: التقرب إلى الله : و التقرب في اللغة من القرب، و" القُربُْ

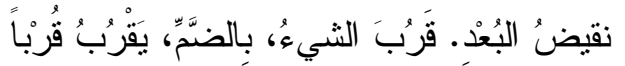

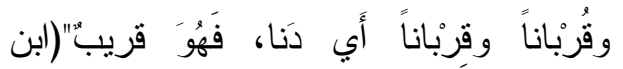

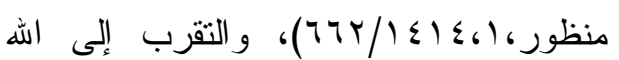

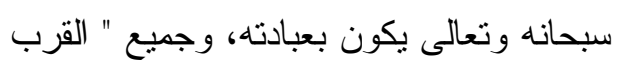

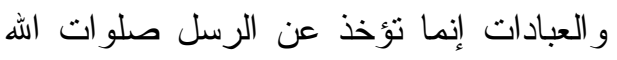

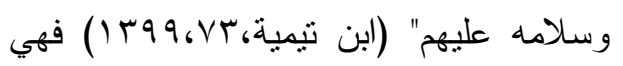

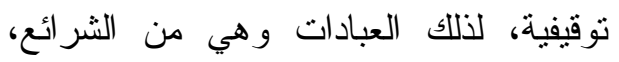
تختلف من أمة إلى أخرى، كما قال سبحانه

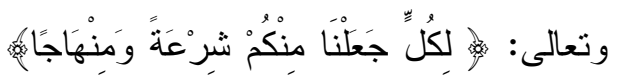

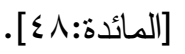
وقصة ابني آدم عليه السلام يَظهر فيها هذا المضمون التزبوي المتعلق بالتقرب إلى الله سبحانه وتعالى، إثنارة إلى أهميته، وتربية آدم

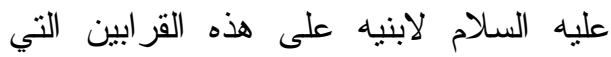

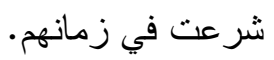


الأول، وأنه أمر ينبغي على العابد أن يهتم

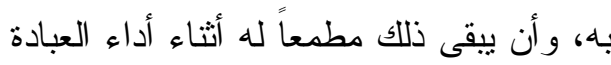
وبعدها.

وجاء التأكيد في الآية بالعناية بقبول العمل عندما اختتمت بسبب من أسباب القبول

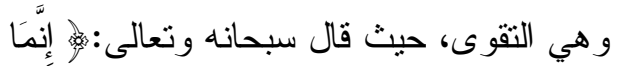

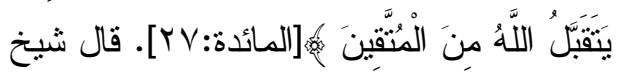
الإسلام ابن نيمية عن ارتباط التقوى بقبول العمل: " وعند أهل السنة و الجماعة بُئقبل العمل ممن اتقى الله فيه فعمله خالصاً لله موافقا لأمر الله، فمن اتقاه في عمل تقبله منه

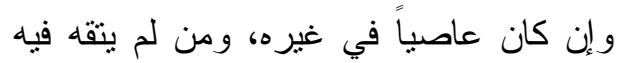
لم يتقبله منه وإن كان مطيعاً في غيره"(ابن

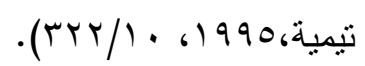
وقبول العبادة هو أمر اهتم به الأنبياء و المرسلون والمؤمنون، فهذا أبو الأنبياء إبر اهيم و ابنه اسماعيل عليهما السلام " فهما في عمل صالح، وهما يسألان اله تعالى أن

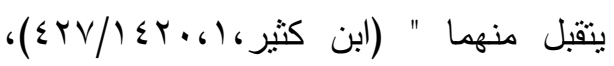

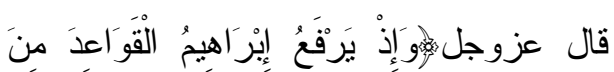

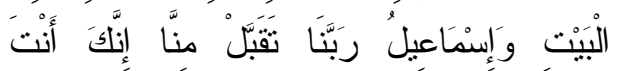

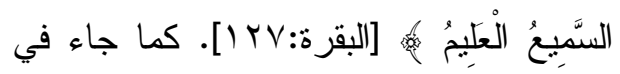
موطن آخر عن إبراهيم عليه السلام طلب

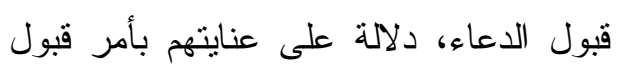

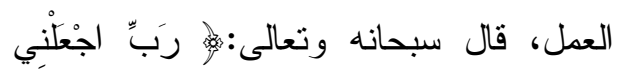

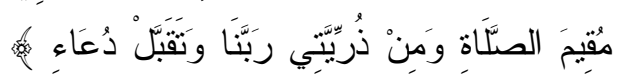

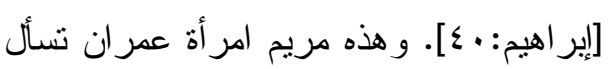

استعاذني لأعيذنه، وما ترددت عن شيء أنا فاعله ترددي عن نفس المؤمن، يكره الموت

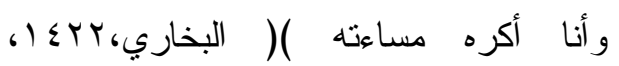
و الثريعة الإسلامية هي من أوسع الثرائع

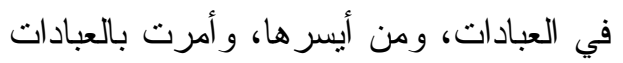
على اختلاف أنواعها: فمنها ما يكون بالقلب،

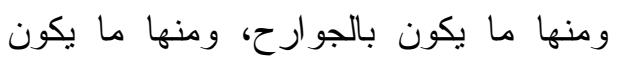

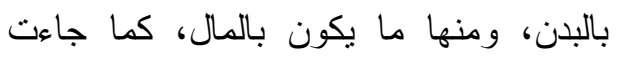

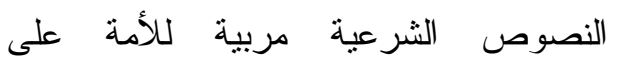
العبادات، و المحافظة عليها بأساليب مختلفة، مرده وبطرق متتوعة، وحركت النفوس بالترغيب و التز هيب، وبالقصة وبالمو عظة الحسنة.

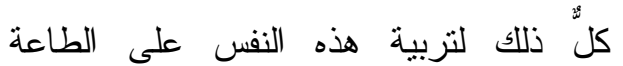

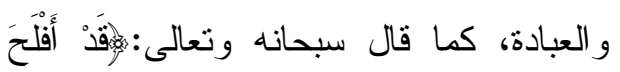

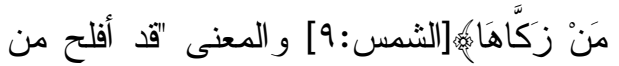
زكّى نفسه بطاعة الهه وصالح الأعمال"(ابن

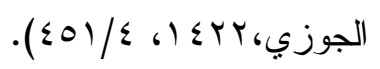
المضموز الرابع : الاهتمام بقبول العمل :

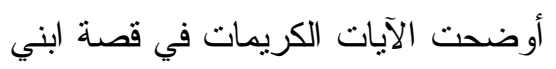
آدم عليه السلام أن القرابين التي تُقدم عرضة لأن تكون مقبولة من عند الله عزوجل، وأن تكون مردودة غير مقبولة، وما كان من حوار من لهار

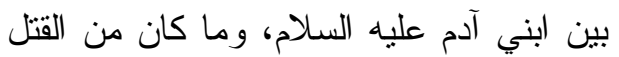
هو بسبب عدم قبول عمل أحدهما. كل ذلك الكان

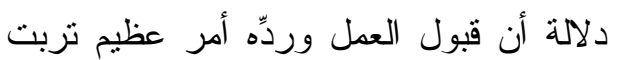
عليه نفوس المتقربين منذ خلق البشرية 


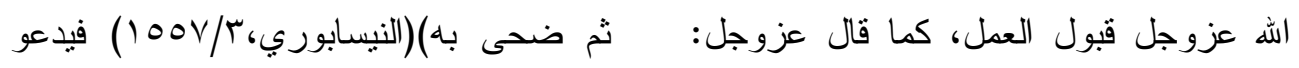

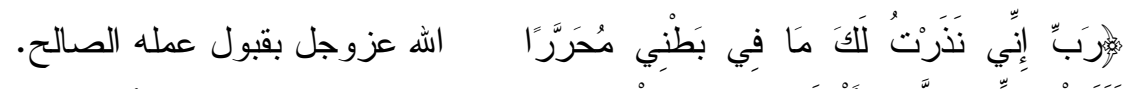

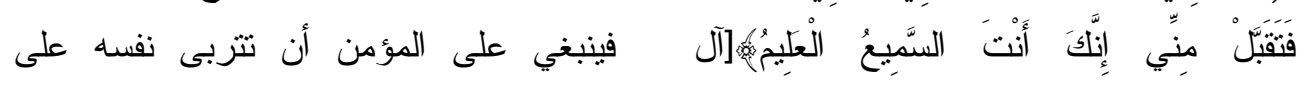

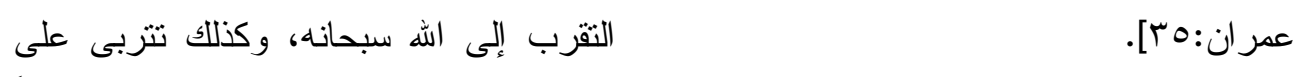
ومما بستثير عناية المؤمن بقبول العمل، الاهتمام بقبول ذلك العمل، فيبقى قلبه متعلقاً

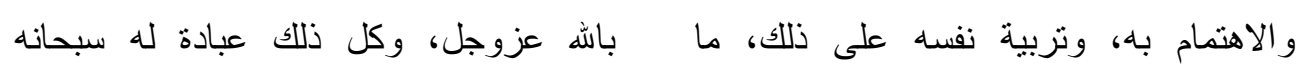

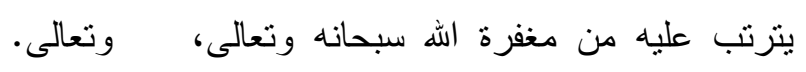

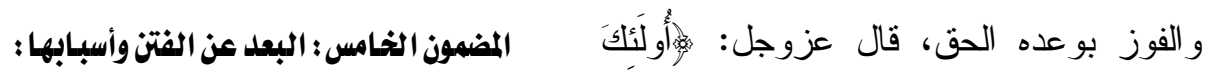

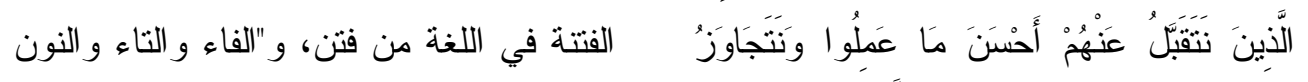

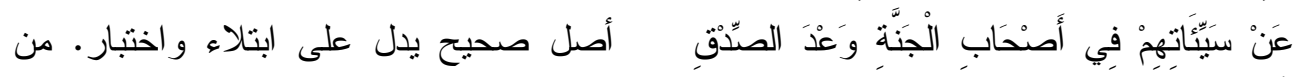

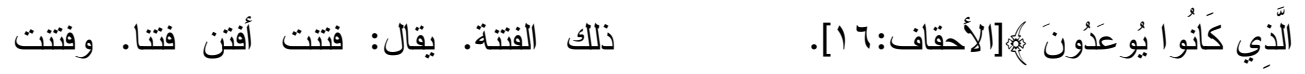
ومما يؤكد الاهتمام بقبول العمل، ما جاء أن الذهب الذب بالنار ، إذا امتحنته. وهو مفتون وفتنين.

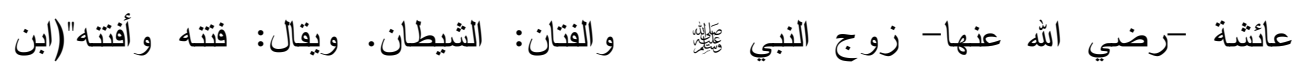

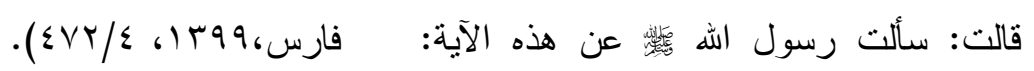

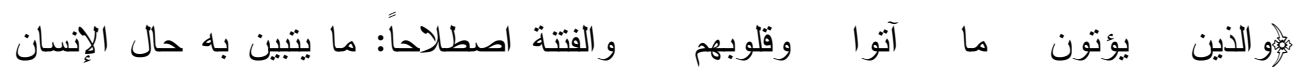

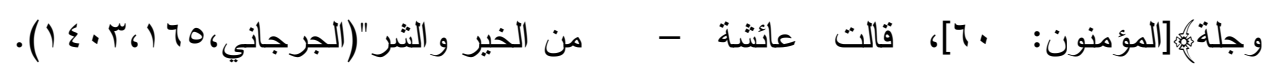

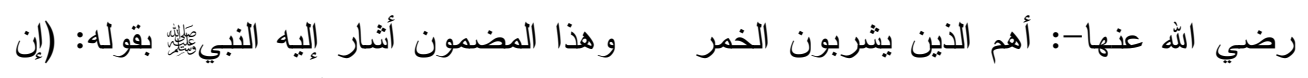

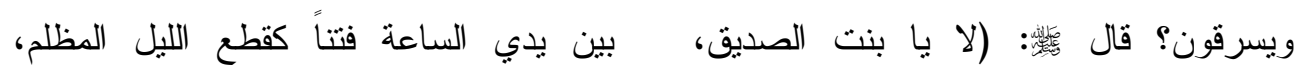

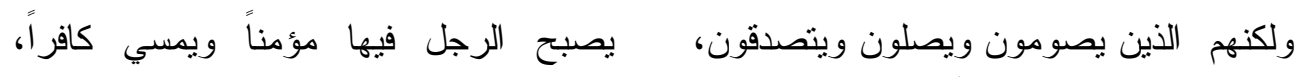

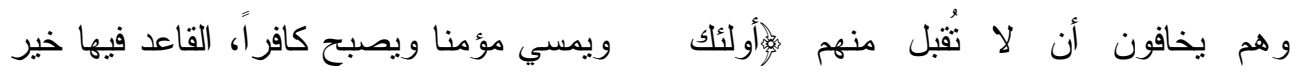
يسارعون في الخيرات وهم لها سابقونه.

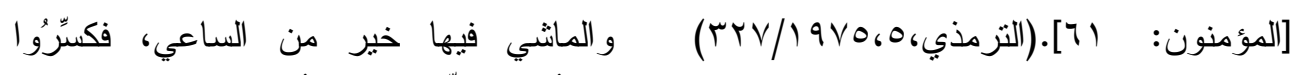

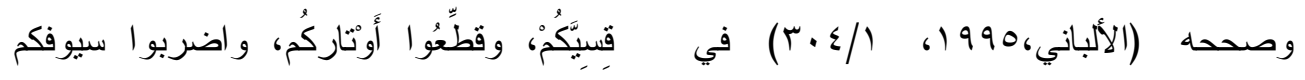

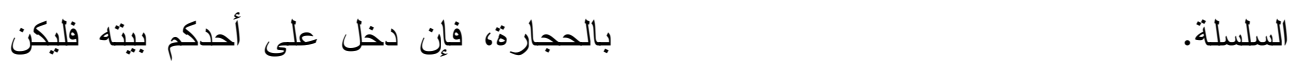

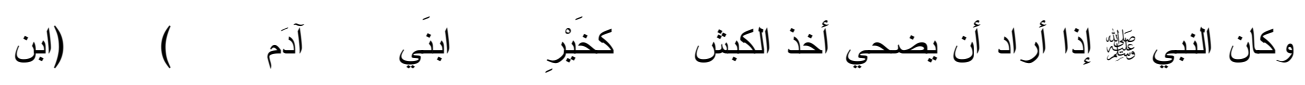

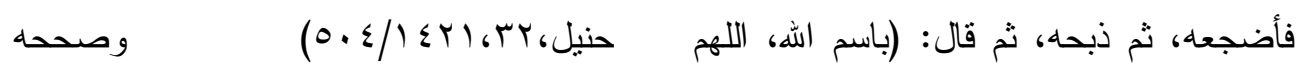

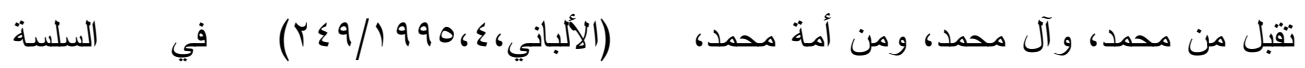




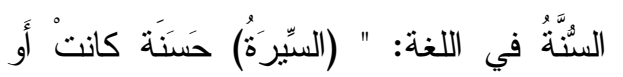

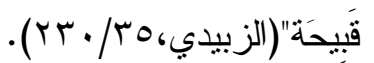

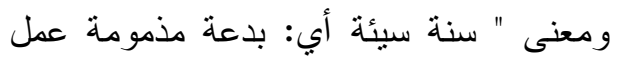

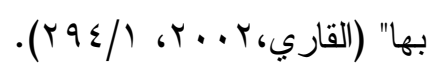

وبناء على المعنى السابق، فالسنة السيئة

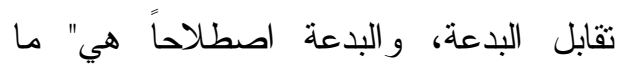
ابتدعه الإنسان، ولم يسبق إليه، ولم يتقدّمه

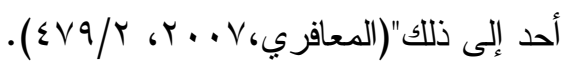
وهذا المضمون من المضامين التي أثنار إليها النبي كان على ابن آدم الأول كفلْ من دمها، لأنه

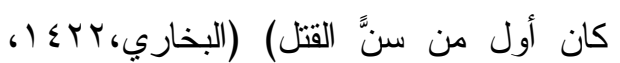

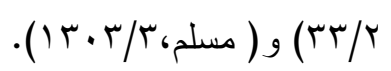

فالنبي الني لأنه أول من سنَّ القتل، وهذا المعنى أكده

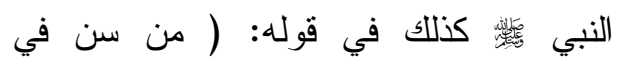
الإسلام سنة حسنة، فله أجرها، وأجر من فن فئ فئ فئ عمل بها بعده، من غير أن ينقص من النها أجورهم شيء، ومن سن في الإسلام سنة

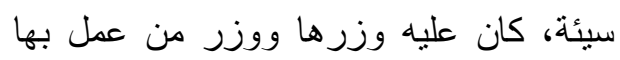
من بعده، من غير أن ينقص من أوزارهم

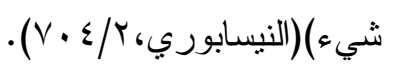

و الحديث "فيه التحذير من السنن السيئة، وأن

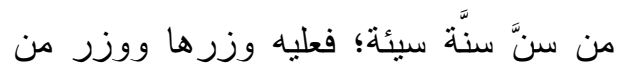

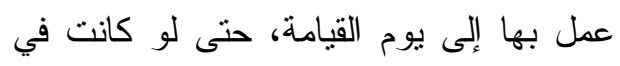

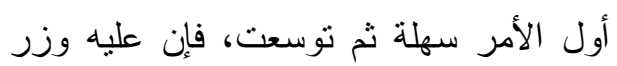

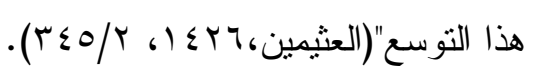

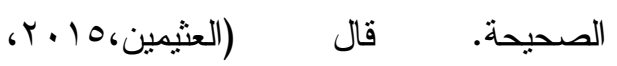
r/T/T)

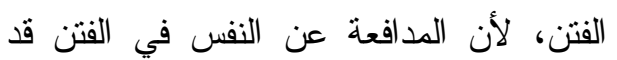
يكون فيها شر" كثثر"، وذلك لماجرى لأمير المؤمنين عثمان كرضي الله عنه- الخليفة

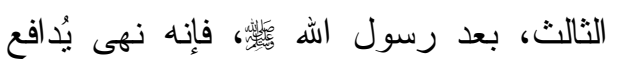
عنه، بل قال لغلمانه: كل إنسان لا يدافع فهو

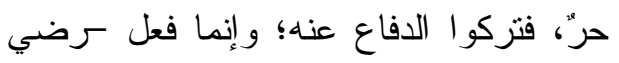

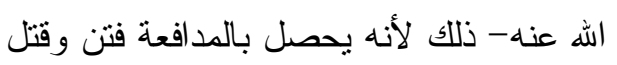
كثير في المدينة النبوية، لذا أراد-رضي الها بله بله عنه- أن يُقتل اتقاءً للاماء). و هذا تأكيد على خطأ كل من يسعى إلى لى لـ ألى

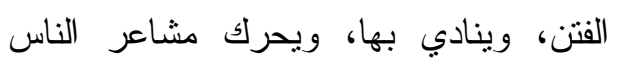
حولها، وهو يعلم سوء عاقبتها من إر اقة لهادي

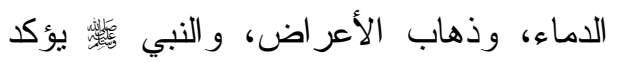

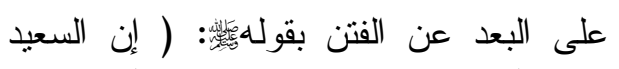

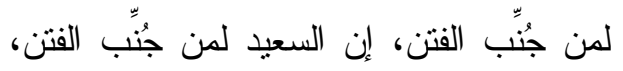

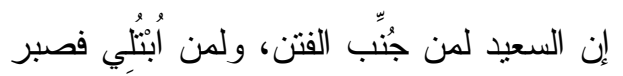

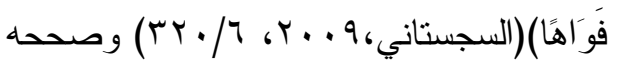

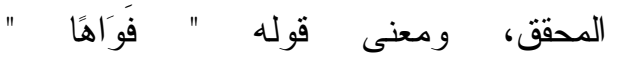

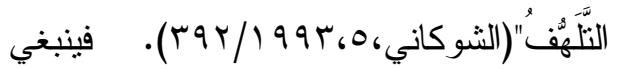
على المؤهن أن يبتعد عن الفتن، وعن أسباب

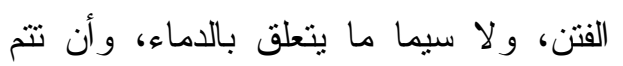

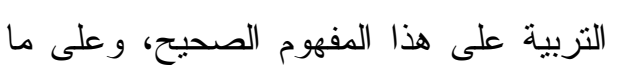
هو دون ذلك فيما يثير الخلاف بين الناس، هئ ولئ ويؤدي إلى تقاطعهم، أو تتاحر هم. المضمون السادس : خطر السُّنَّة السيئة : 


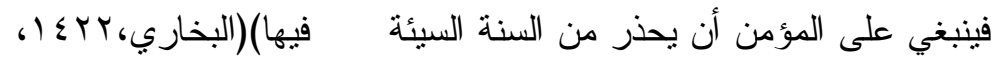

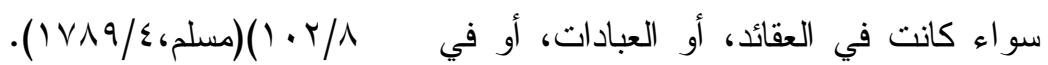

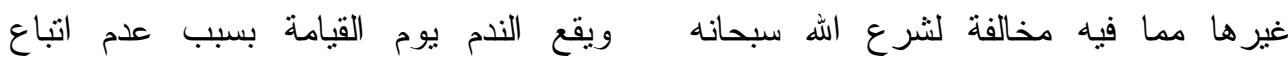

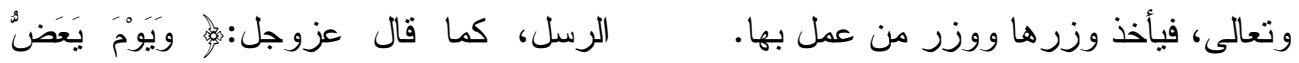

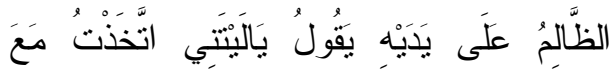

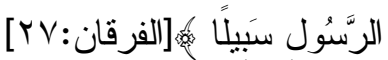

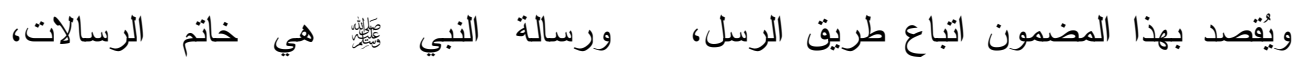

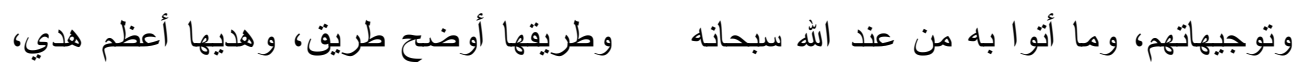

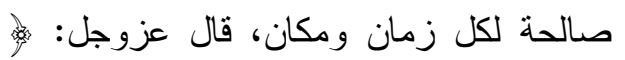

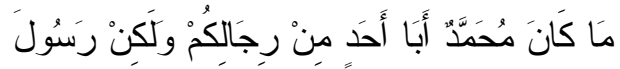

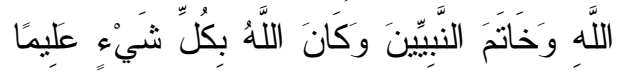

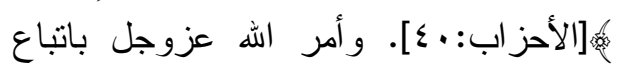

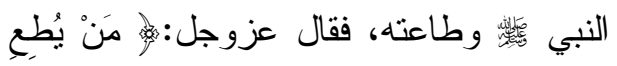

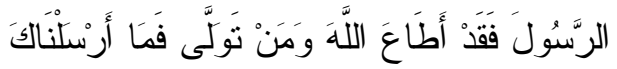

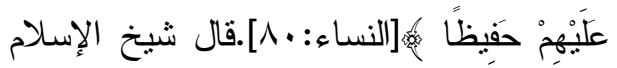
بن ثيمية" وقد أمر اله بطاعة رسوله صلى

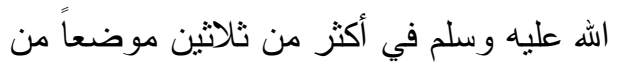

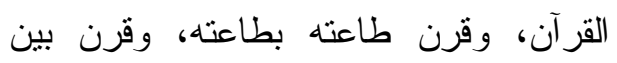
مخالقته ومخالفته، كما قرن بين اسمه و واسمه بطه

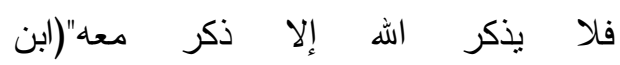

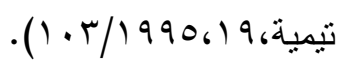

وجاءت السنة النبوية تؤكد على أهمية طاعته

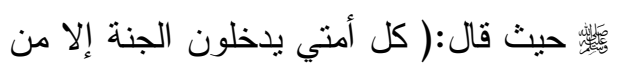
أبى)، قالو ا: يا رسول الله، ومن يأبى؟ قال:

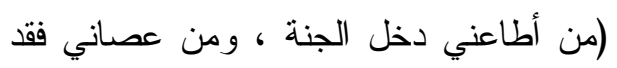

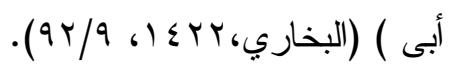
وتعالى من العقائد و الثرائع.

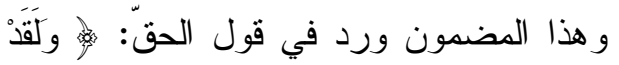

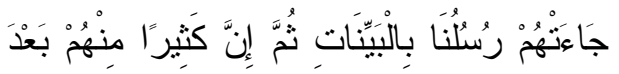

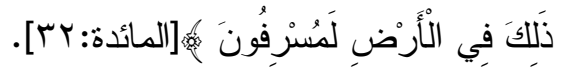
وأرسل اله عزوجل الرسل لهداية الناس إلى لى لـ

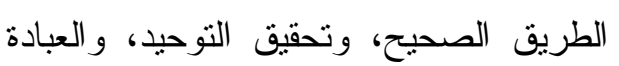

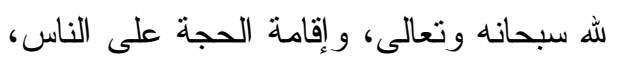

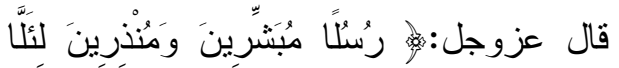

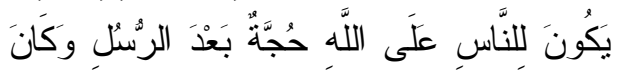

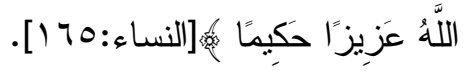
كما أرسل اله الرسل ليبين للناس الطريق

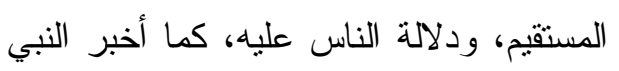

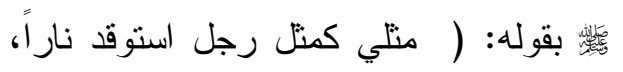
فلما أضاءت ما حولها جعل الفراش وهذه رهن الدواب التي في النار يقعن فيها، وجعل ملاعل يحجزهن ويغلبنه فيتقحن فيها، قال فذلكم

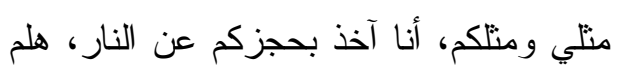
عن النار، هلم عن النار فتغلبوني تقحمون 
و الاجتماعي من جَمَعَ، وجَمَعْتُ الثََّّْهَ جَمْنًَا

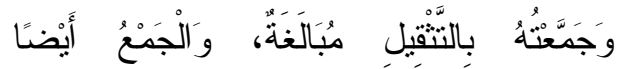

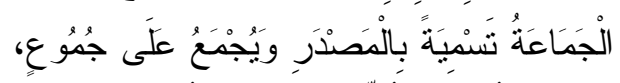

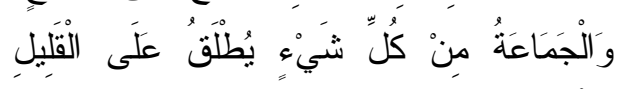

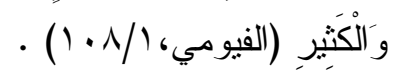

والاجتماعي اسم منسوب إلى اجتماع الناس

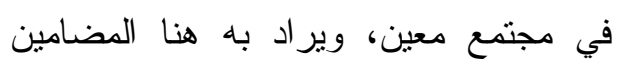
التربوية المتعلقة بعلاقة أفر اد المجتمع.

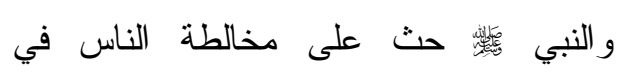

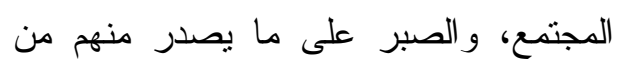

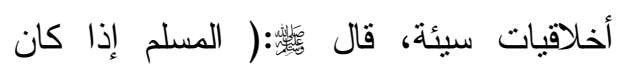

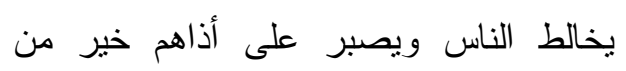

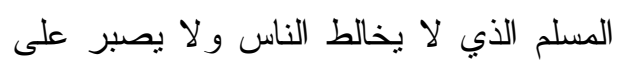

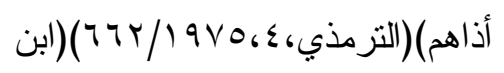

وصححه

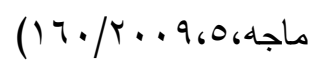

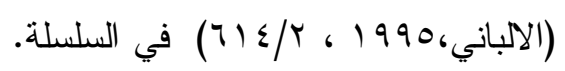

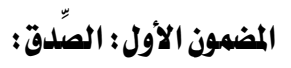

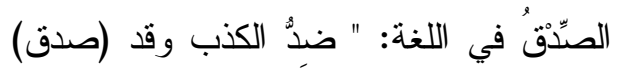

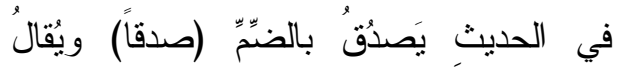

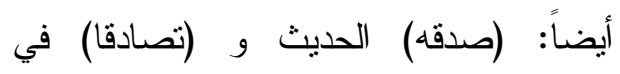

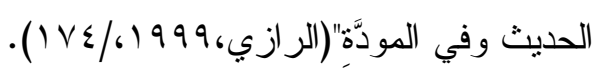

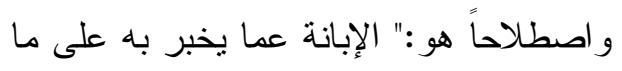

$$
\text { كان" (الجرجاني، وس ا () ). }
$$

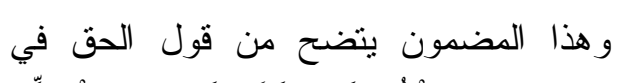

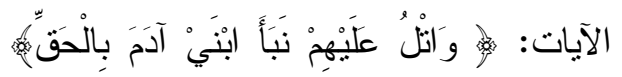

$$
\text { أي بالحق و الصدق. }
$$

فينبغي الاهتمام بالتربية على طاعة النبي

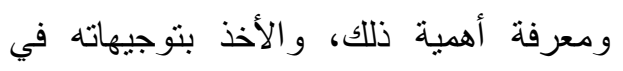
جميع شؤون الحياة، والتعرف على مآلات الته الأمم السابقة في مواقفهم مع أنبيائهم في هذا على مالات

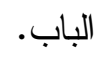
ثانيـاً : المـضامين التربويــة المستنبطة في الجانسب الأخلاقي والاجتماعي:

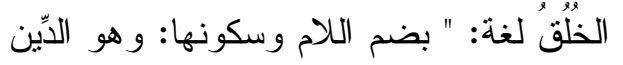
و الطبحُ و السجيّةُ، وحقيقته أنه لصورة الإنسان الباطنة، و وهي نفسه و وأوصافها و ومعانيها المختصة بها، بمنزلة الخَلَق لصورته الظَاهرة

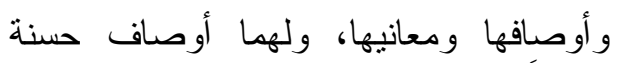

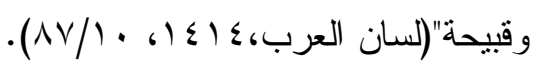
و الأخلاق اصطلاحاً:" عبارة عن هيئة للنفس

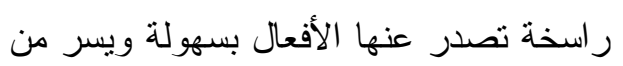
غير حاجة إلى فكر وروية، فإن كانت الهيئة بحيث تصدر عنها الأفعال الجميلة عقلًا وشرعًا بسهولة، سميت الهيئة: خلقًا حسنًا،

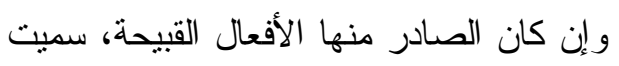

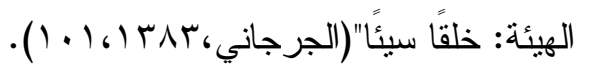
ومكانة الأخلاق عظيمة في الإسلام،

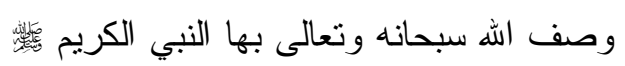

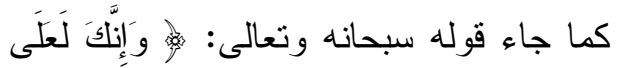

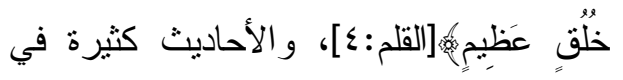
بيان مكانة الأخلاق في الإسلام، منها قول

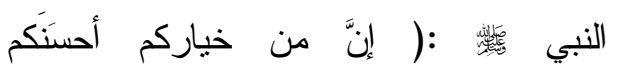

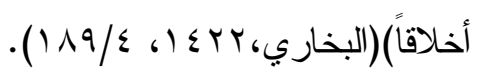


دوماً في أقو اله و أفعاله، و أنه يجتهد في امتناله لهذا الخلق. وجاء الأمر في الصدق في جميع جوانب

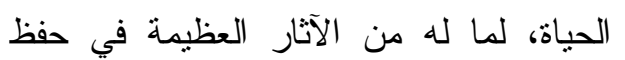
علاقة الناس بعضهم ببعض، وأمان الناس لهن

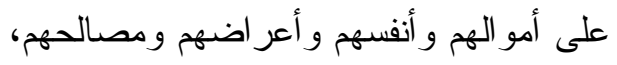
وهو طريق إلى البركة في الرزق، وفي البيع

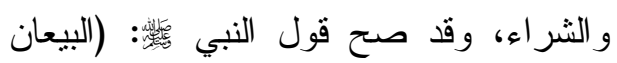
بالخيار ما لم يتفرقا فإن صدقا وبينا، بورك ولئ لهما في بيعهما، وإن كذبا وكتما، محق بركة

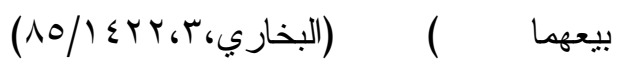

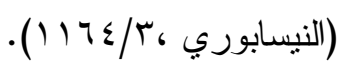

ومن جميل هذا الخلق أنه يجعل الباطن و الظاهر صورة واحدة، وتعمل على اصلاح

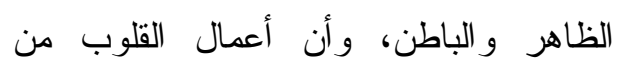
الإيمان باله سبحانه وتعالى، وما يتبعها من ون اعنال

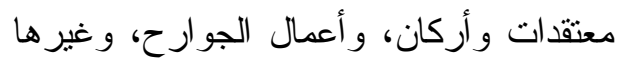

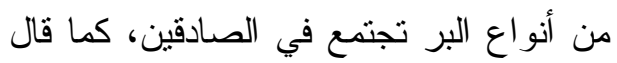

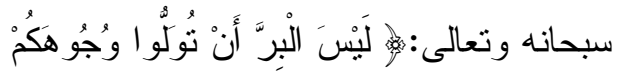

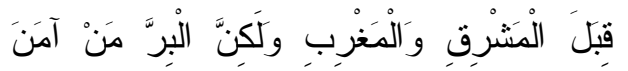

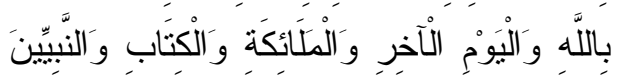

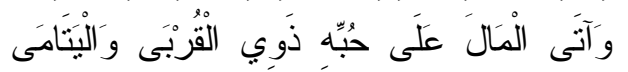

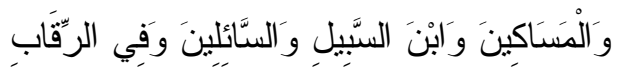

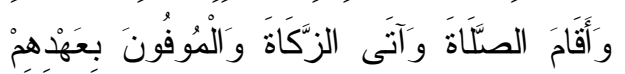

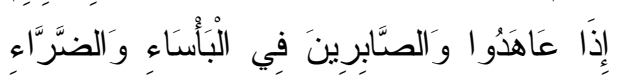

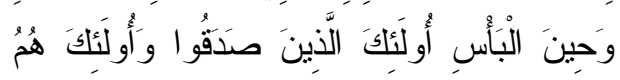

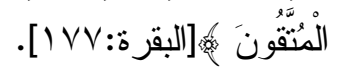

و الآيات في كتاب اله سبحانه وتعالى كثيرة التي تؤكد على هذا المضمون، وتأمر به، وتبين آثاره، ومن ذلك أنَّ الله عزوجل وصف لهذ

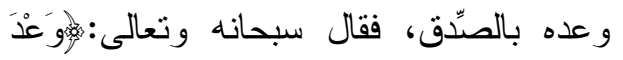

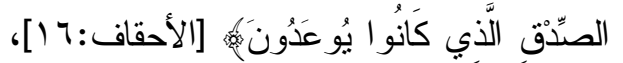

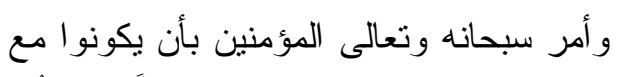

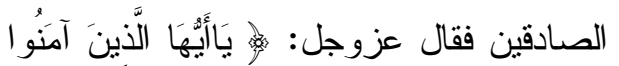

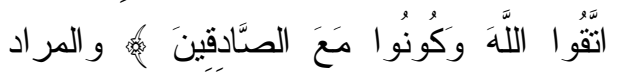
الصِّق في كلّ شيء " في أقو الهم و أفعالهم

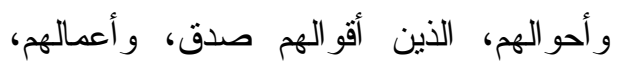
و أحو الهم لا تكون إلا صدقاً خليةً من الكسل وله و الفتور، سالمةً من المقاصد السيئة، مشتملةً

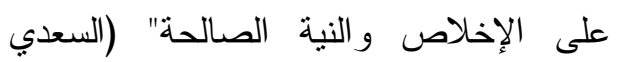
. (ro0 6.... وجاءت السنة المطهرة مؤكدةً على أهمية هذا

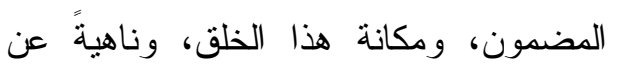
ضده من الخلق، فقال

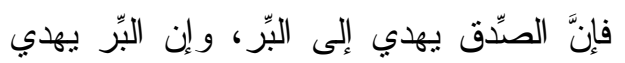

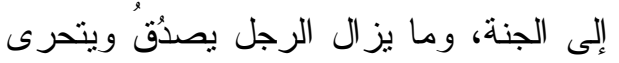
الصنّدق حتى يُكتبَ عند الله صديقا، وإيَّاكم و الكذب، فإنَّ الكذب يهذي إلى الفجور ، وإن إن

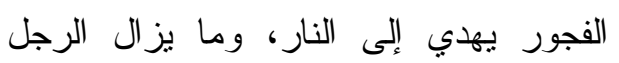
يكذب ويتحرى الكذب حتى يكتب عند الله

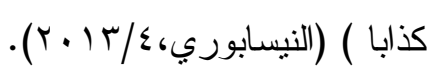

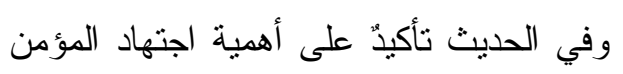

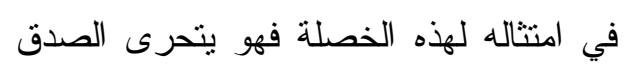




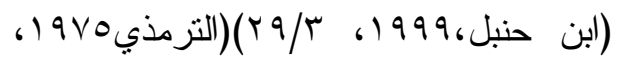

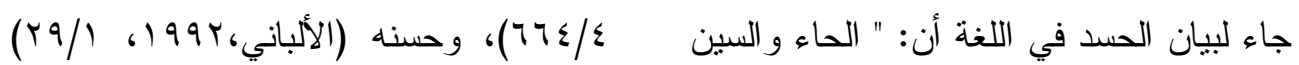
و الدال أصل و واحد، وهو الحسد" (ابن ولى في السلسلة. وما وقوعه في ابتداء أمر ابني

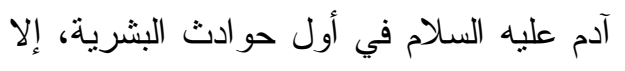
تحذير أ من شره، وبيان خطر ه، وسو ع عاقبته.

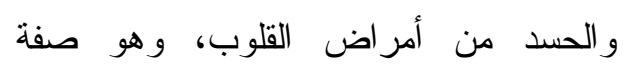

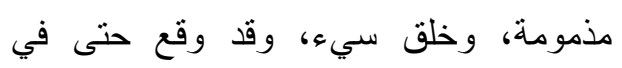

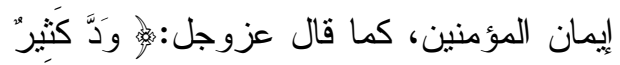

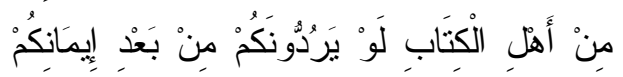

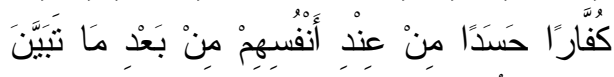

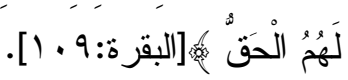
وقد جاءت الآيات بذم الحسد، كما قال

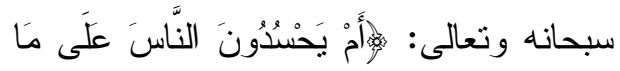

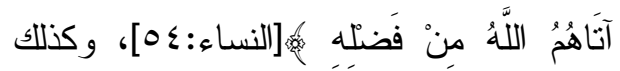
جاءت السنة المطهرة بالنهي عن الحسد، فال 。

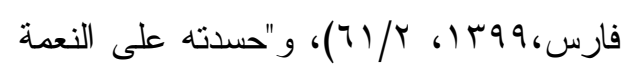

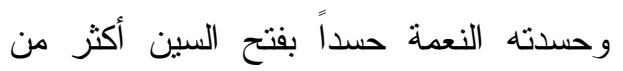
سكونها يتعدى إلى الثاني بنفسه وبالحرف إذا لفأ

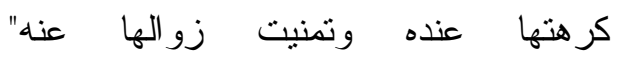

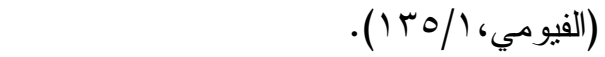
ومن أثنهر تعاريف الحسد اصطلاحاً أنه: "

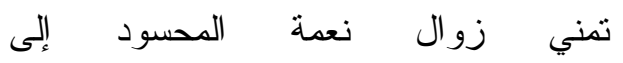

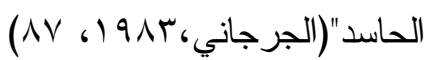
وقد نص جمع من المفسرين عند تفسير الآيات التي وردت فيها قصة ابني آدم عليه السلام على أن الحسد هو الذي دفع صاحبه إلى القتل.

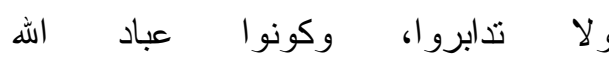

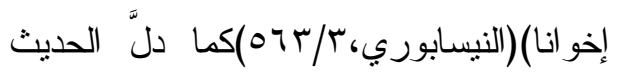

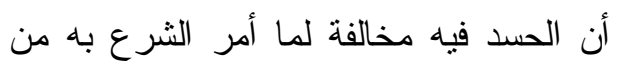

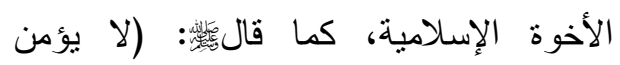
أحدكم، حتى يحب لأخيه ما يحب لنفسه)

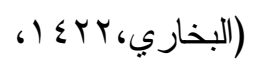
و التعريف المشهور للحسد يذكر الحد الأدنى

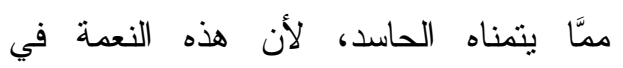
المحسود هي ابتداء وقوع الحسد ومحركه لأهناه لاى الحاسد، ثم يتبع ذلك من الشرِّ ما الله به وابه

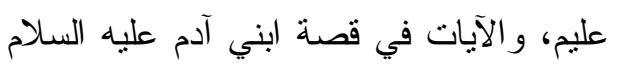

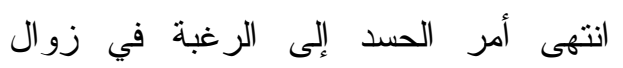

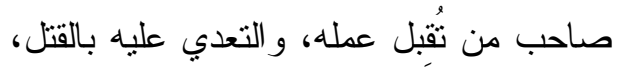

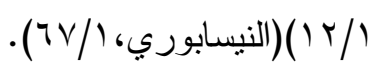
وقد صرح علماء التفسير عند تفسير قصة وللحسد أضر ار كثثرة، "فالحسد أولاً يضر

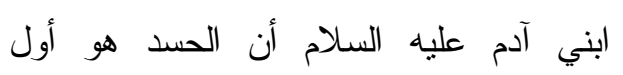

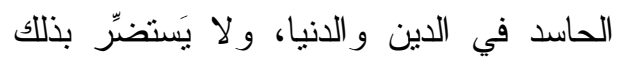
المحسود، فلا تؤذ نفسك. أما ضرره في الدين ولاني

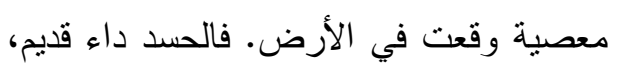
كما أخبر النبي

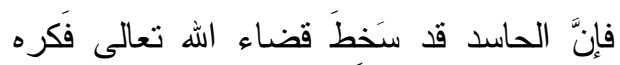
الحسد و البغضاء) (الطيالسي، (1999/1 1999) 


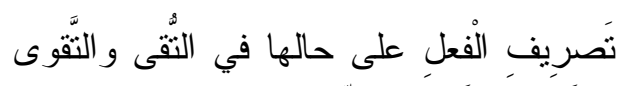

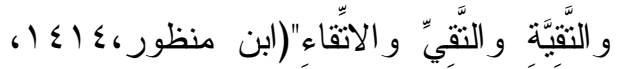

$$
\text { . }(\varepsilon \cdot \varepsilon / 10
$$

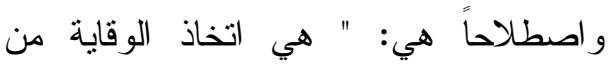
عذاب الله عز وجل بفعل أوامره، واجتناب

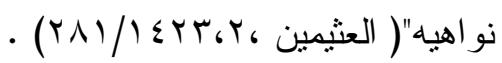
وقد ذكرت الآيات في قصة ابني آدم عليه السلام هذا المضمون صر احة، بل جعلته سبياً

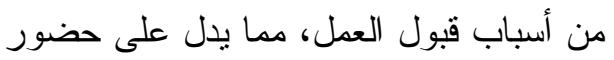
هذا المضمون لدى أبناء آدم عليه السلام، لئل و على تربيتهم عليه. وقد أمر الله سبحانه وتعالى بالتقوى في آيات

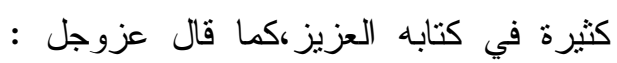

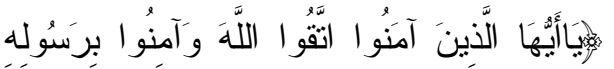

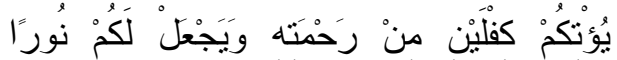

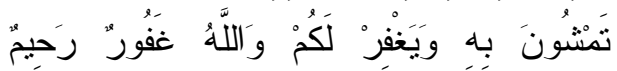

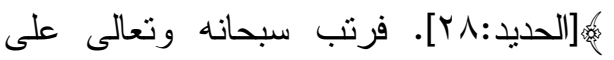
تقواه في هذه الآية الكريمة الخير العظيم،

$$
\text { و الفضل الجزيل. }
$$

وجاءت الآيات لتربط بين تقوى الله سبحانه وتعالى، وبين المخرج من كل ما يلم الإنسان

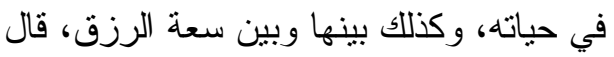

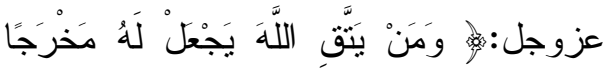

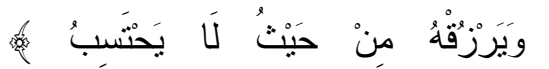

$$
\text { [الطلاق:r-r"r] }
$$

و الأحاديث الواردة في الأمر الثقوى كذلك كثبرة لأهميتها، وقد كان النبي الأبه بسأل ربَّه
نعمته على عباده، وهذا قذى في بصر

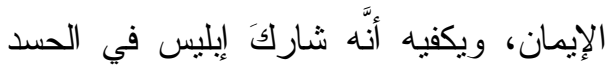

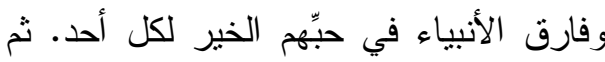

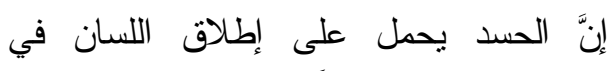

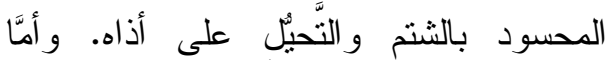

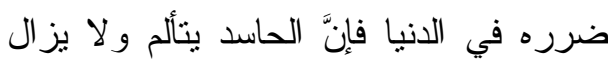

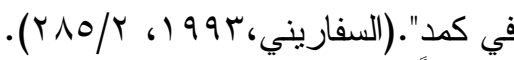

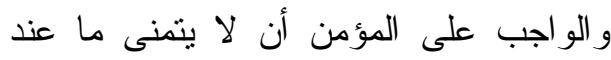

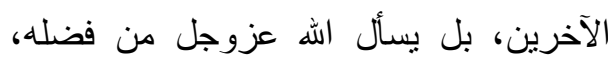

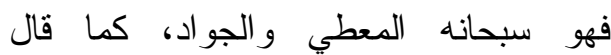

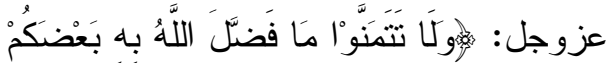

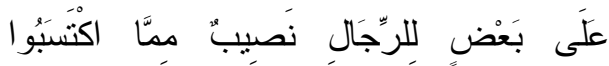

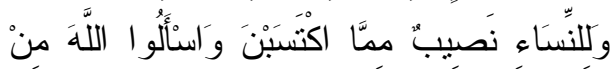

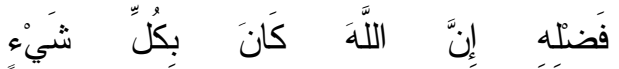

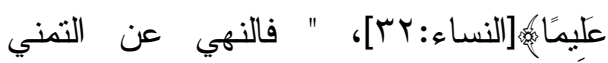
وتطلع النفوس إلى ما ليس لها جاء في هذه الآية عاماً...وقد كان التمني من أعظم وسائل هاء فئل

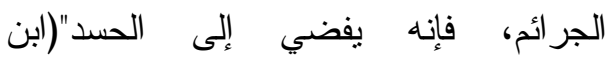

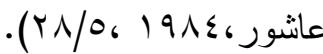
كما ينبغي على المؤمن أن يزكي نفسه عن في الهن هذه الآفات، ويجاهدها في دفع ما يجده في ني تلني

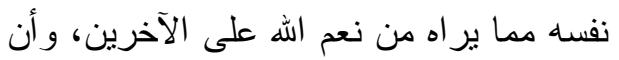
ينوجه إلى اله عزوجل ويطلب منه الفضل و الكرم و الجود فهو أهله سبحانه وتعالى. المضمون الثالث: تقوى الله :

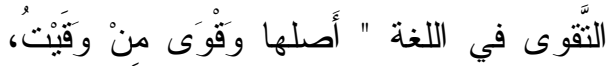

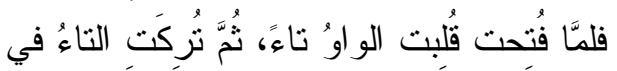


سبحانه وتعالى ويقول: ( اللهم إني أسألك الحق من عدم الاعتداء، وتجاوز الحدّ بقتله،

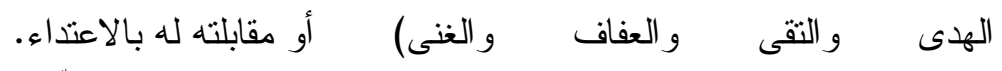

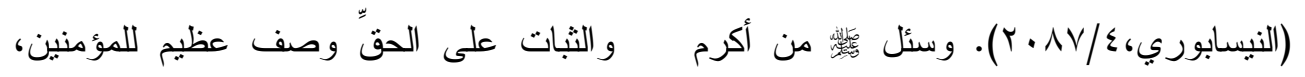

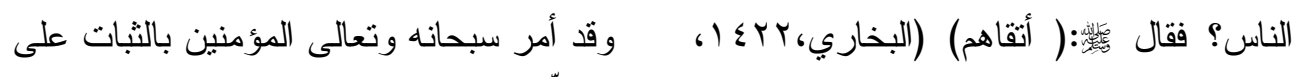

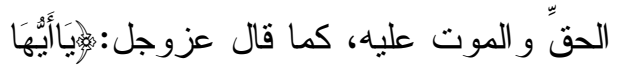

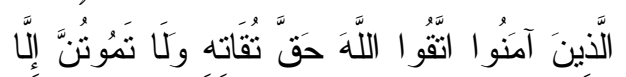

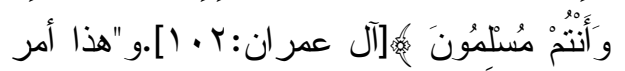

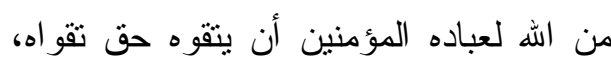

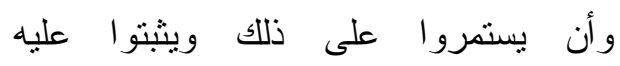
ويستقيموا إلى الممات" (السعدي ، ، ب...

وقد كان من دعائه له

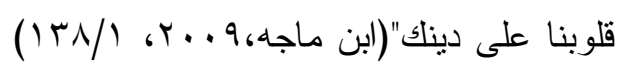
وصححه محقق الكتاب.

فينبغي على المؤمن أن يجتهذ في ثباته على

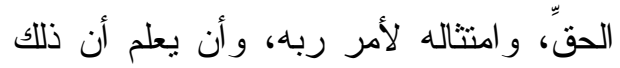

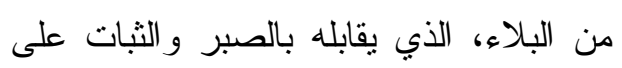

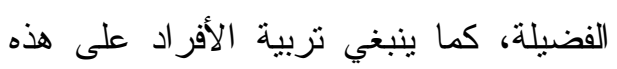

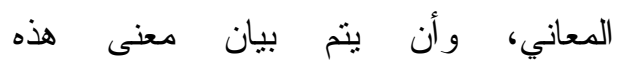
المصطلحات، وتطبيقاتها المهمة في مواطن لمن لئن الثندّة .

\section{المضمون الخامس : الحذر من سوء عاقبة الظله :} الظلم في اللغة" مصدر ظلمتُه أظلِمه ظلَمْاً،

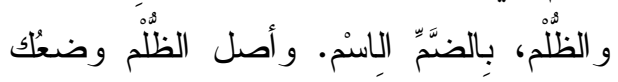

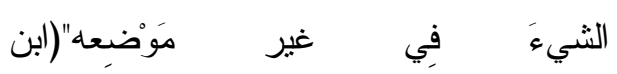

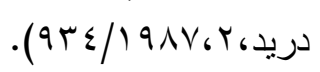
والأحاديث النبوية تربط دائماً بين الأمر

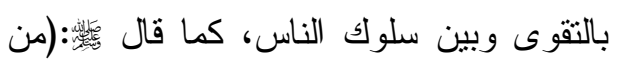
حلف على يمين، ثم رأى أتقى لله منها، فليأت

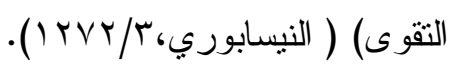
فينبغي على العبد أن تكون تقوى الله سبحانه

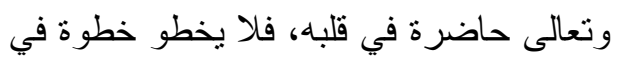
هذه الدنيا وإلا وهو بعطم أنها في الطريق الصحيح الذي تتحقق معه تقوى الله عزوجل، ولأل وأن تتم التزبية على تقوى اله عزوجل في لتحفي السرّر و العلانية.

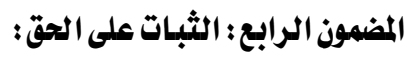
الثبات لغة من " ثبت الثيء يثبت ثبوتا دام الرات الثياء و استقر فهو ثابت"(الفيومي، / •ـ).

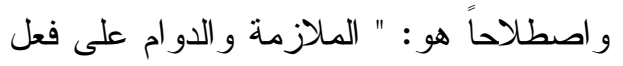

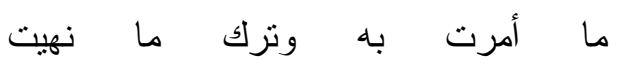

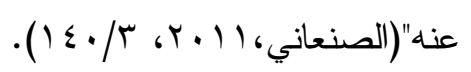
وهذا المضمون يظهر من خلال ثبات المعتدى عليه بالقتل من ابني آدم عليه السلام

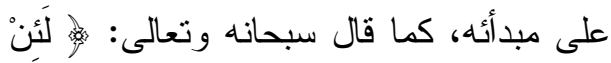

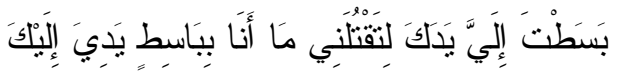

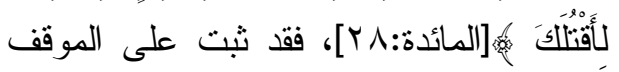


و الظلم اصطلاحاً: " عبارة عن التعدي عن للك، وتحرص على التربية على احترام الحق إلى الباطل، وهو الجور" (الجرجاني، حقوق الآخرين، وتحذر من التعدي عليها.

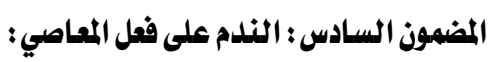
.) (1) $\leqslant$ ، 19Ar

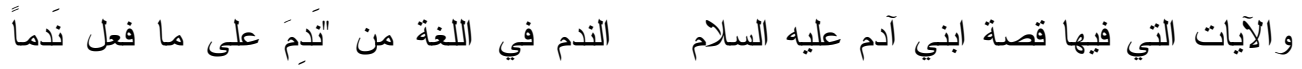

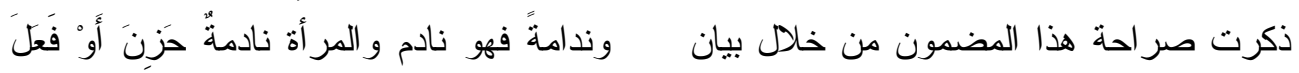

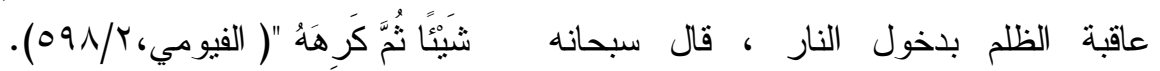

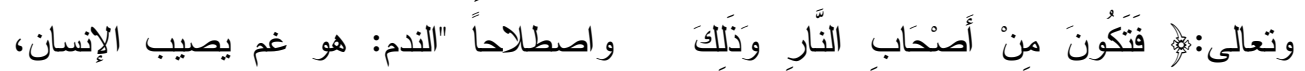

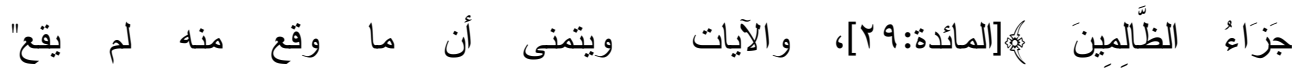

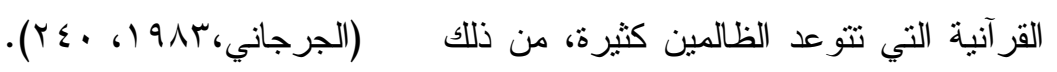

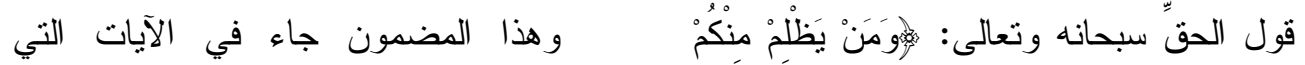

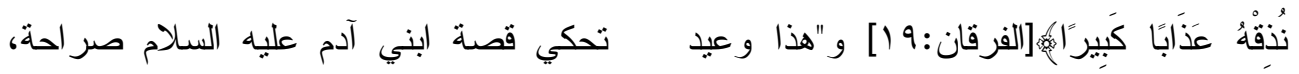

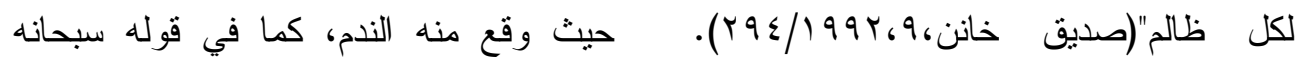

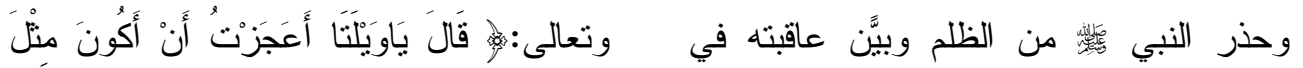

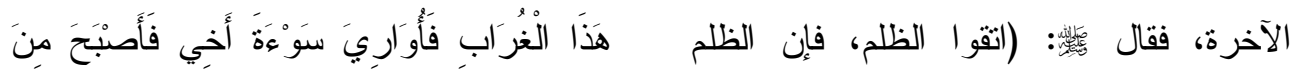

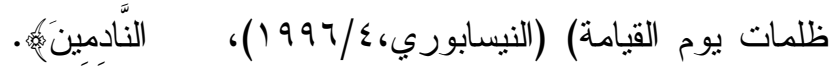

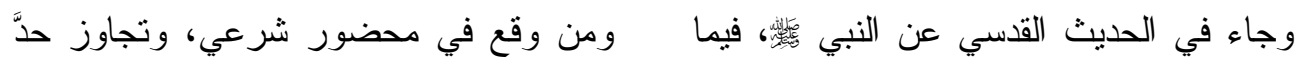

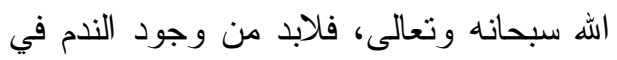

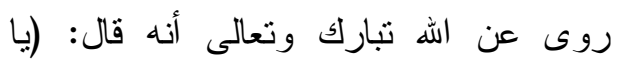

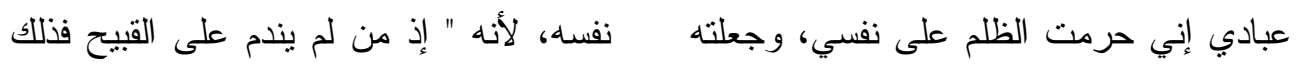

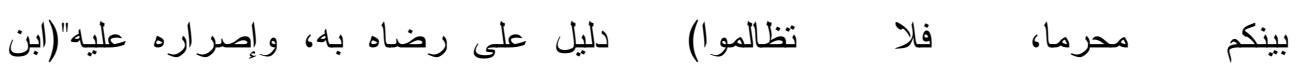

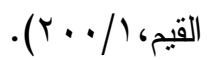

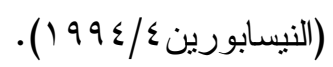

و الندم هو أحد شروط النوبة، حيث إن "أكثر

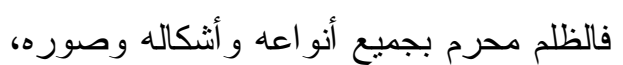

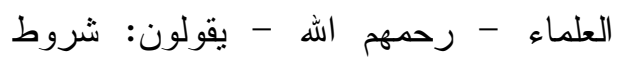
التوبة ثلاثة: الندم، والإقلاع، و العزم على أن سواء كان ظلم الإنسان لنفسه، أو لغيره، فينبغي على المسلم أن يحرص أن يكون نقياً

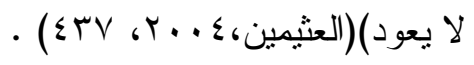
من الظلم، و لا سيما ما كان في حقِّ الله

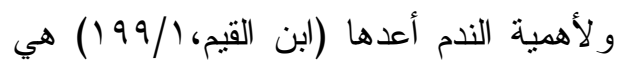
سبحانه وتعالى من الثرك به، أو مع الناس التوبة، حيث قال: "فحقيقة التوبة: هي الندم الندان

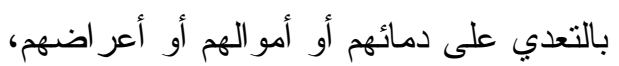

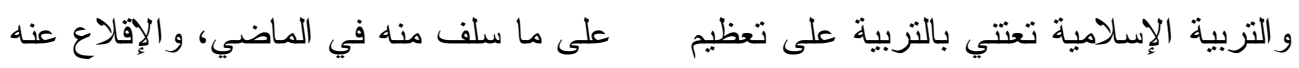


القتل فيها كان أكبر خطأ وقع، وعليه مدار القصة، وما ذكره الله عزوجل من وعيد في القتل يبين خطر التعدي على النفس بإز هاقها. و الاعتداء على النفس أمر عظيه، وخطره

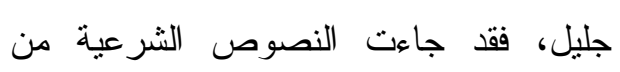
كتاب اله عزوجل وسنة النبي من بفعل ذلك. فمن ذلك أن اله عزوجل نهى عن قتل فتل النفس،

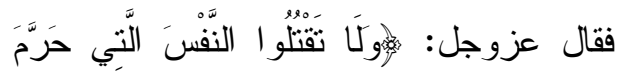

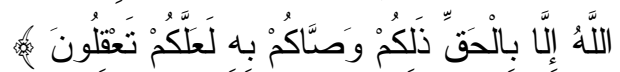

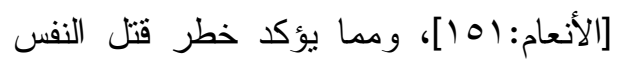

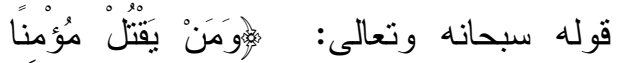

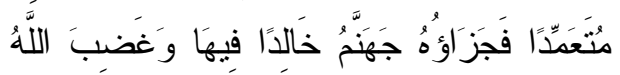

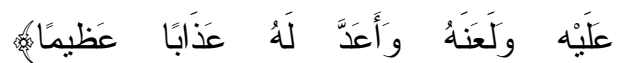

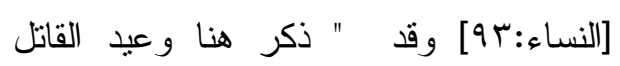

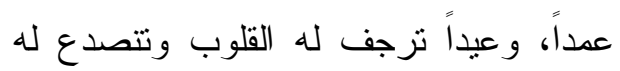
الأفئدة، وتنز عج منه أولو العقول. فلم برد في تي

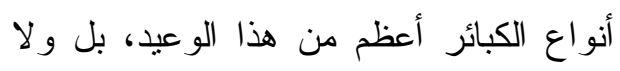

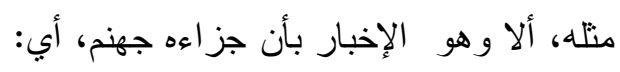

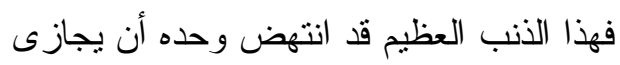
صاحبه بجهنم، بما فيها من العذاب العظيه،

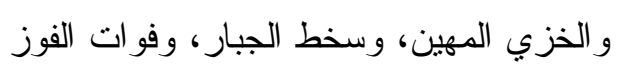

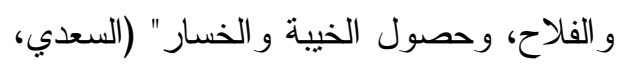

$$
\text { . (19) ، r... }
$$

وكذلك جاءت السنة المطهرة بما يحذر من التعدي على هذه الأنفس المعصومة،

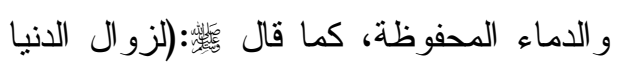

في الحال، و العزم على أن لا بعاوده في المستقبل".

و أثندُ الندامة التي تقع عند فو ات الأوان، وقيام

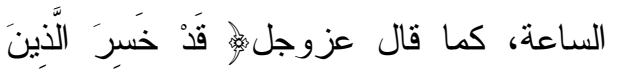

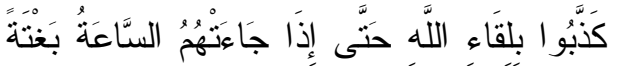

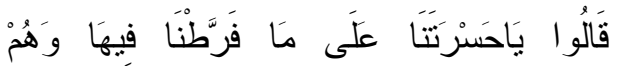

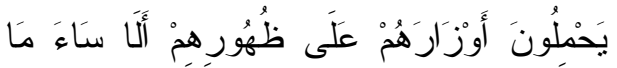

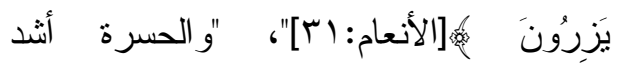

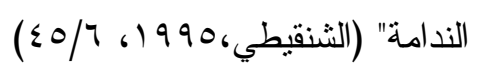
إن ندم المسلم على سوء عمله في الدنبا نعمة

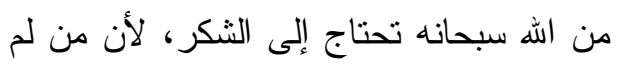
يندم في الدنيا وهو في حال الرخاء، سبندم

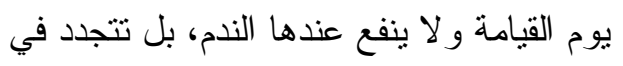
ذللك اليوم الحسر ات.

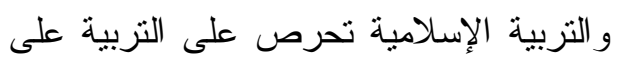

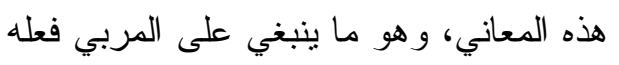

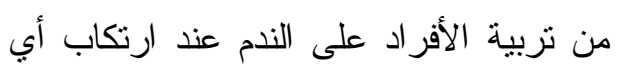

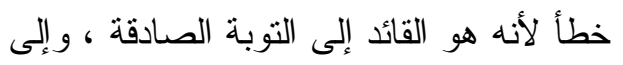
صلاح السلوك و النفوس. المضمون السابع : خطر قتل النفس :

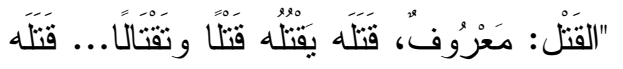

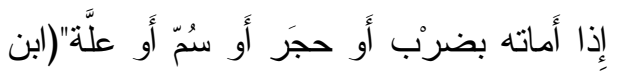

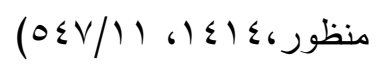

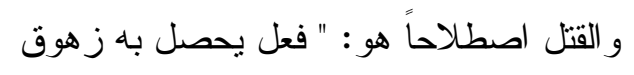

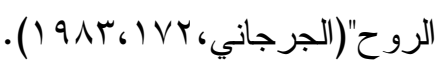

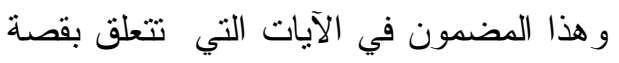
ابني آدم عليه السلام و اضح وجلي، حيث الابن 
أهون على الله من قتل مؤمن بغير حق) بالرعاية في سنواتهِ الأولى، والوعائُ التقافي

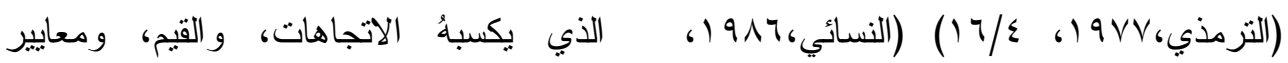

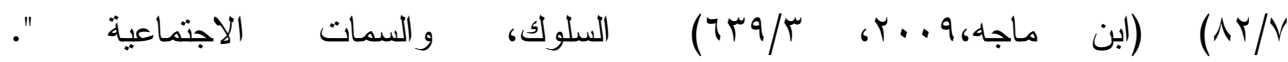

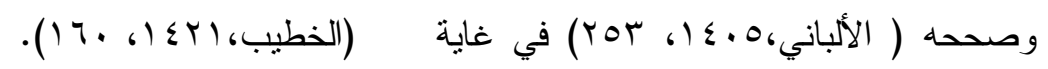

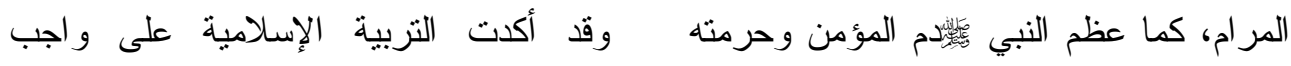

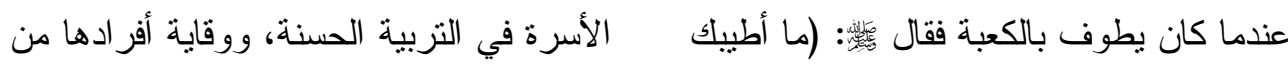

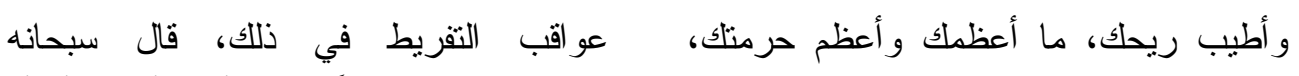

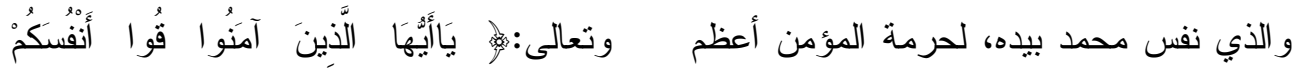

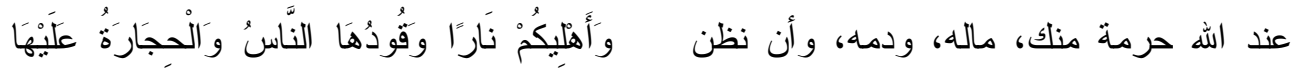

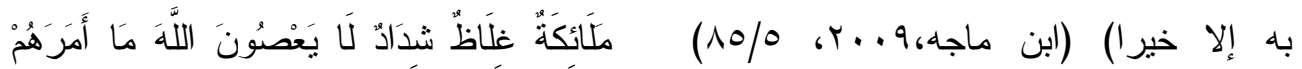

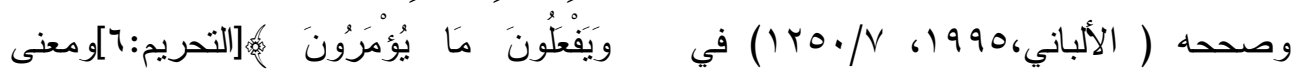

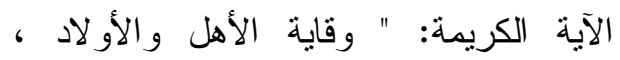

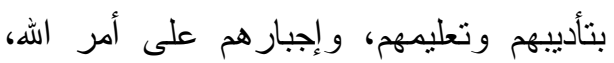

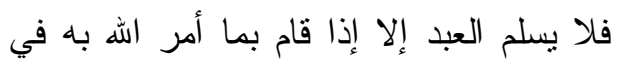

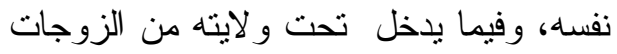

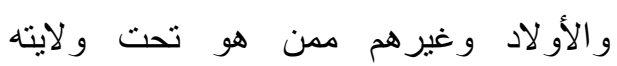

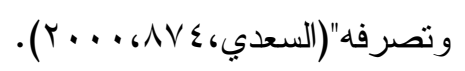

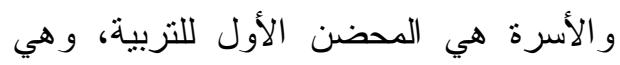

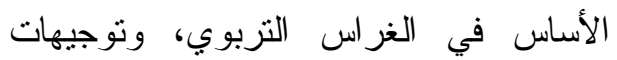

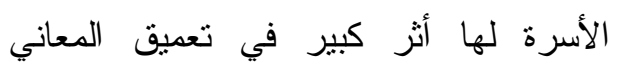

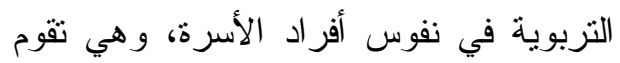

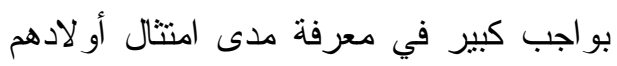

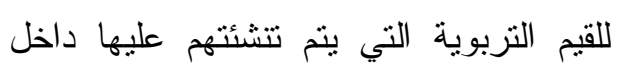
الأسرة، أو ما تم تعزيز ها خارجها من خلال

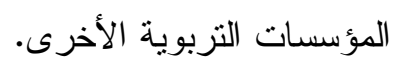

وتم اختيار الأسرة للتطبيقات التزبوية في التربي البحث لتعلق موضوع الدراسة لقصة وقعت للتحن

السلسلة.

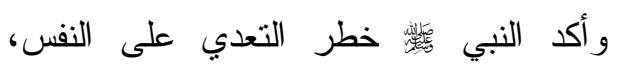

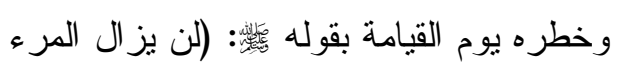

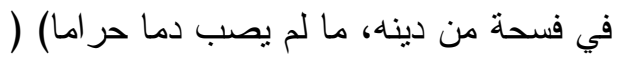

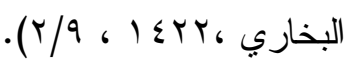
فينغغي أن تربى الأمة على تعظيم دماء

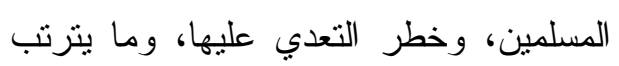
على ذلك من الو عيد في الدنيا والآخرة.

التطبيقات التربوية للمضامين التربوية المستنبطة

\section{من قصة ابني آدم عليه السلام في الأسرة:}

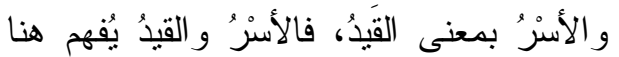

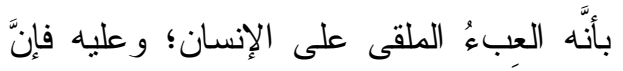

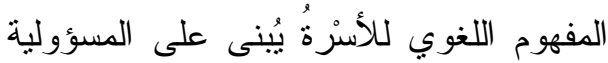

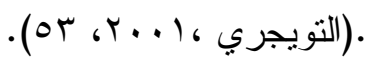

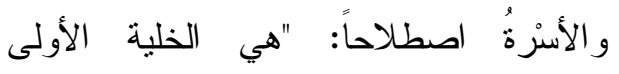
للمجتمع، والبيئة الطبيعيةُ التي تتعهُء الطفل 
خامساً: عقد لقاء أسبوعي يتم فيه نتاول أحد هذه المضامين، والتذكير بها وربطها

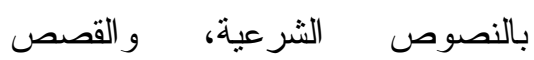

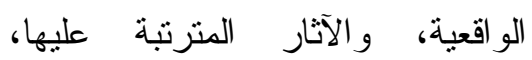
و إثر الك أفر اد الأسرة بشكل متتاوب في عرض بعض النصوص الثرعية، و التعليق عليها بما يستثير الاهنمام بهذه المضامين.

سادساً: تكليف الأبناء بعمل مقابلة مع بعض المض الأقارب، أو مع أفر اد جماعة المسجد حول رأيهم في بعض المض المضامين التربوية، منل: محاسبة النفس، أو البعد عن الفتن، أو البعد عن الحسد، وتحديد الأسئلة في الأثار لذلك.

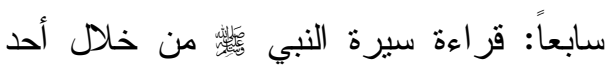
الكتب المختصرة، وقيام أفراد الأسرة

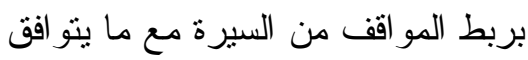
مع المضامين التربوية بهذف تعزيزها. ثامناً: قيام الأسرة بورشة عمل يتم فيها ربط

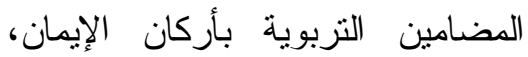
مثل الربط بين مضدون البعد عن الحسد وركن الإيمان بقضاء الهه وقدره،

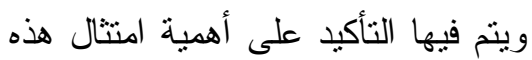

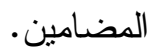

تاسعاً: تحذير الأسرة لأبنائها من مصاحبة من لا بمتتل هذه المضامين التربوية، وبيان خطرهم، ممن لديهم تطاول على حدود
بين أخوين من أسرة واحدة، ولأن المضامين

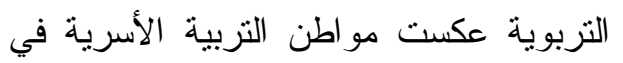

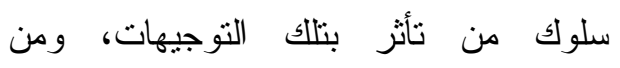

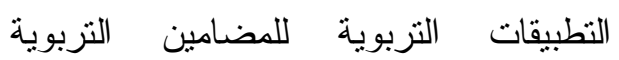
المستتبطة من قصة ابني آدم عليه السلام في الأسرة، ما يأتي: أولاً: أن تعلم الأسرة أن عليها أنسا واجباً تربوياً عظيماً في نربية أولادها، التربية

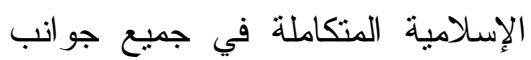
حياتهم العقدية و التعبدية و الاجتماعية والأخلاقية. ثانياً: تضع الأسرة هذه المضامين التزبوية في قائمة اهتمامها التي ستقوم بتربية أو لادها عليها. ثالثاً: تستخدم الأسرة الأساليب المختلفة في

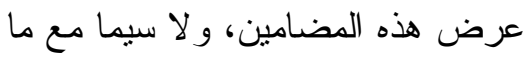
ينتشر في مواقع التواصل الاجتماعي

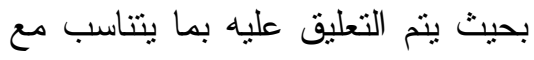
الموقف، منل مضمون الخوف من الله عند مشاهدة ما بخالف ذلك، و التعليق عليه بالنصوص الشرعية المناسبة .

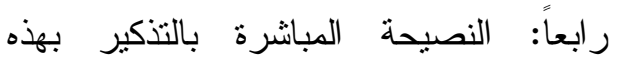
المضامين عند الوقوع بما يخالفها، مثل لن

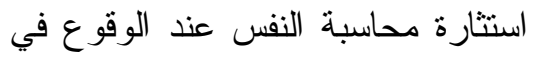
خطأ شرعي، مثل مخالفة توجيهات

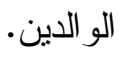




$$
\begin{aligned}
& \text { ه. إن القتل ذنب عظيم وأول مرة يقع بـين } \\
& \text { ابني آدم عليه السلام. } \\
& \text { T. إن المنهج الصحيح هو الإعر اض عـن الصن }
\end{aligned}
$$

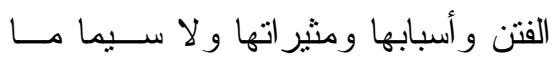

$$
\begin{aligned}
& \text { يتعلق منها بالدماء. }
\end{aligned}
$$$$
\text { V. إن التربية لا بد أن تؤكد تكــون شــاءملة }
$$

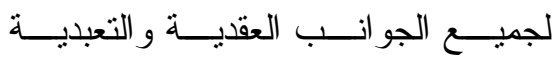$$
\text { والأخلاقية والاجتماعية لما يترتب عليها }
$$$$
\text { من آثار سلوكية على الأفراد. }
$$

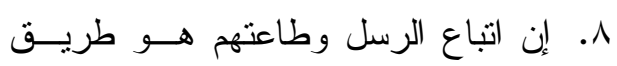$$
\text { النجاة في الانبا و الآخرة. }
$$

9 9. خطورة السنة السيئة وما يتبعها من حمل

$$
\text { أوزار العاملين بها. }
$$

\section{توصيات الدراسة :}

في ضوء نتائج الدراسة الحالية يوصسي

$$
\text { الباحث بما يلي: }
$$

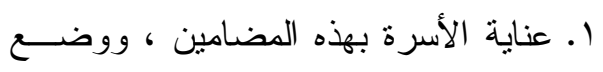

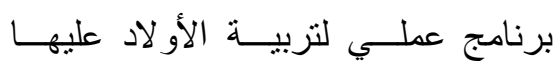

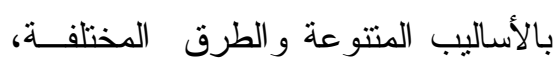

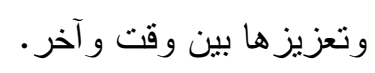

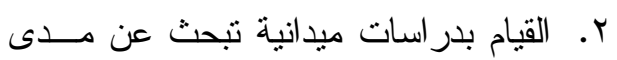

$$
\text { الوعي بهذه المضامين التربوية. }
$$

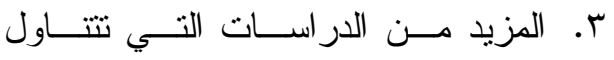

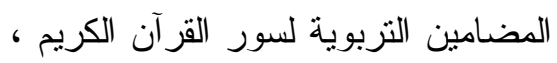

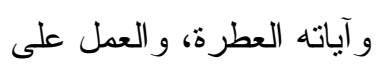

الله سبحانه وتعالى، ومخالفة أمره

بالتعدي على دماء الناس، أو حسدهم لهم، أو ظلمهم، وبيان سوء عاقبتهم. عاشر اً: قيام الأسرة بذكر المواقف الحياتية الو اقعية أو الافتر اضية والمرتبطة بهذه بذرة

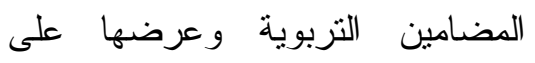
الأو لاد ، و التي يظهر مع هذه المو اقف وعن

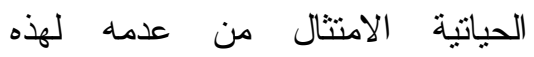
المضامين، ويُطلب من الأولاد إبداء

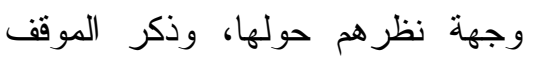

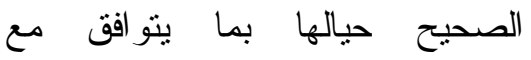
توجيهات التربية الإسلامية. خلاصة النتائج : 1. إن قصة ابني آدم عليه السلام رغم قصر

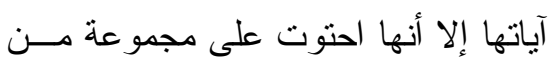

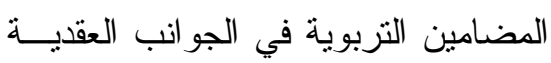
و التعبدية، و الأخلاقية و التعبدية.

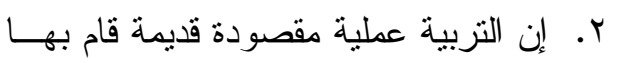

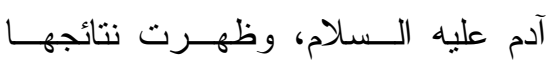

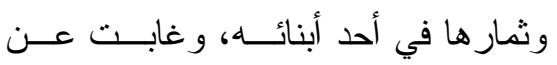
الآخر r. إن الدور التربوي نحو القيم الإســلامية

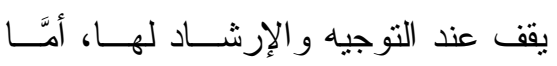

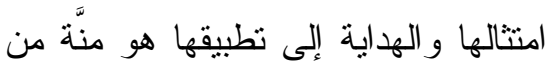

$$
\text { الله سبحانه وتعالى. }
$$

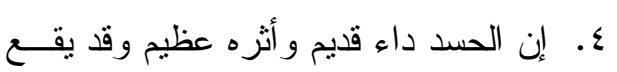
بين أقرب الناس. 
ه. ابن عاثنور، محمد الطاهر بن محمد بن

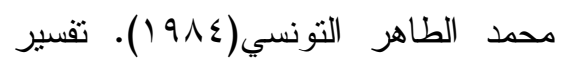
التحرير و التتوير • تونس: الدار التونسية للنشر 7. ابن فارس، أحمد بن فارس بن زكريا القزويني الرازي، أبو الحسين(99 با 1): معجم مقاييس اللغة، تحقيق: عبد السلام محمد هارون، بيروت: دار الفكر.

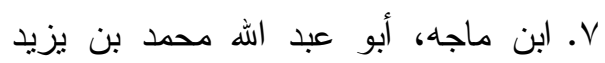

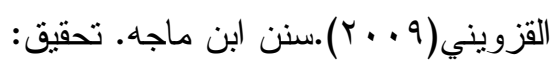
شعيب الأرناؤوط، عادل مرشد، محمَّد

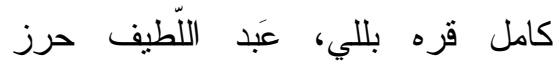
الله.طا ـ بيروت: دار الرسالة العالمية.

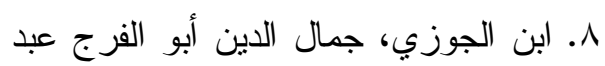

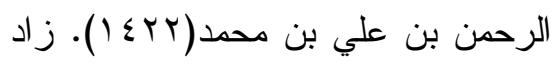

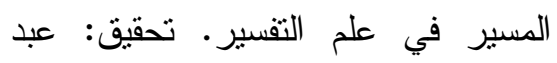
الرزاق المهدي.طا.بيروت: دار الكتاب

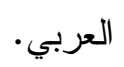

9 ـ ابن القيم، محمد بن أبي بكر بن أيوب بن

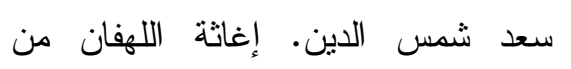
مصايد الشيطان. تحقيق: محمد حامد الفقي. الرياض: مكتبة المعارف.

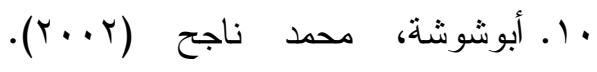
المضامين التربوية في أهم مصادر

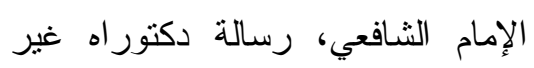
منشورة. قسم أصول التزبية. كلية
تحليلها، واستتباط مــضـامينها التربويـــة

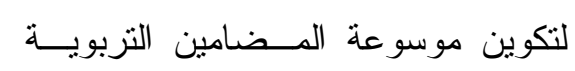
للقر آن الكريم.

\section{المصادروالمراجع :}

ا ـ ابن تيمية، تقي الدين أبو العباس أحمد بن عبد الحليم بن عبد السلام بن عبد الله بن بن السين أبي القاسم بن محمد ابن تيمية الحراني

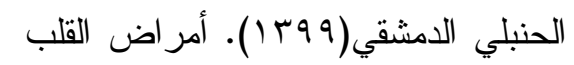
وشفاؤ ها.ط r.القاهرة: المطبعة السلفية. r. ابن تيمية، تقي الدين أبو العباس أحمد بن

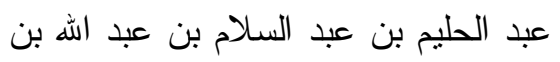
أبي القاسم بن محمد ابن تيمية الحراني

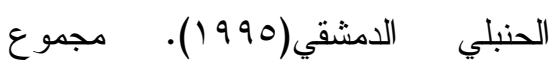
الفتاوى، جمع: عبدالرحمن بن محمد بن

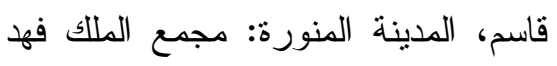

$$
\text { لطباعة المصحف الثريف. }
$$

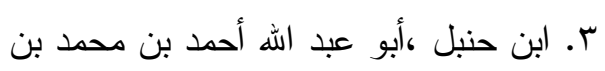
حنبل بن هلال بن أسد الثيباني. مسند الإمام أحمد بن حنبل. تحقيق شعيب الأرناؤوط و عادل مرشد، و آخرون.طا

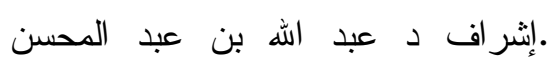
التركي .الرياض: مؤسسة الرسالة. ع. ابن دريد، أبو بكر محمد بن الحسن مؤن لرسن

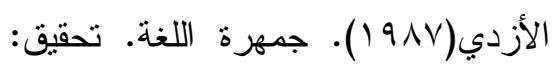

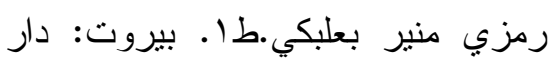
الملاين. 


$$
\begin{aligned}
& \text { الثربية بسو هاج. جامعة جنوب الوادي. المهدي.ط ا بيروت:دار إحباء التزاث } \\
& \text { مصر • م العربي. }
\end{aligned}
$$

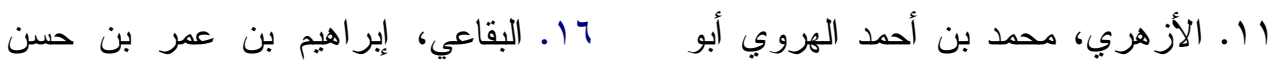

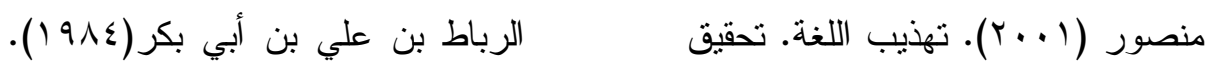

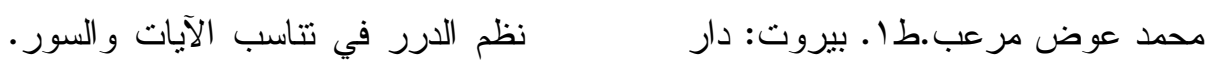

$$
\begin{aligned}
& \text { إحياء التزاث العربي. القاهرة: دار الكتاب الإسلامي. } \\
& \text { Y Iا. الألباني، أبو عبد الرحمن محمد ناصر }
\end{aligned}
$$

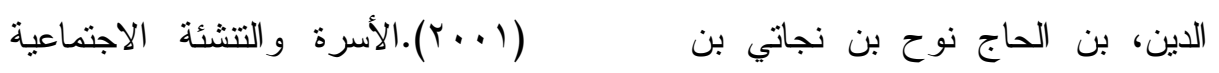

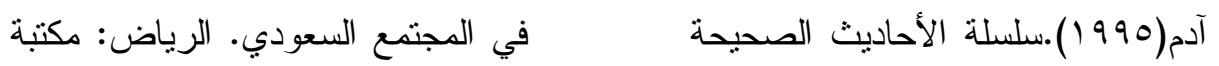

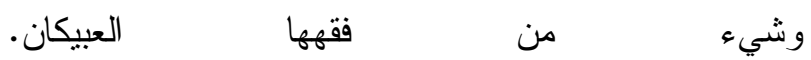

$$
\begin{aligned}
& \text { وفو ائدها.ط ا.الرياض: مكتبة المعارف 1 1. الجرجاني، علي بن محمد بن علي }
\end{aligned}
$$

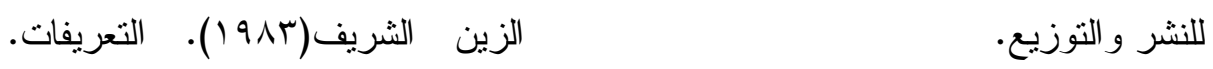

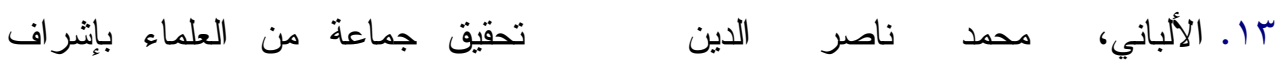

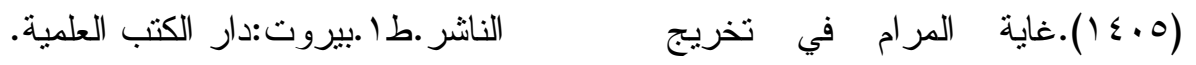

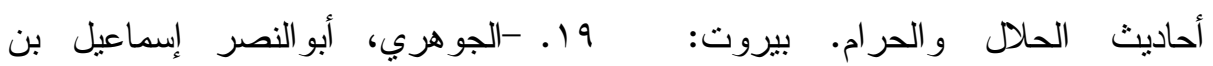

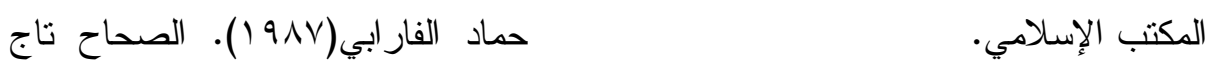

$$
\begin{aligned}
& \text { ع ا. البخاري، محمد بن إسماعيل أبو عبداله اللغة وصحاح العربية. تحقيق: أحمد }
\end{aligned}
$$

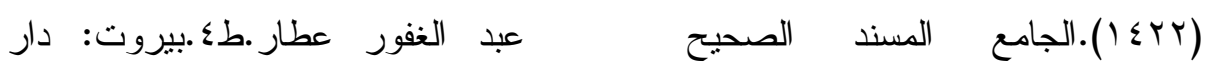

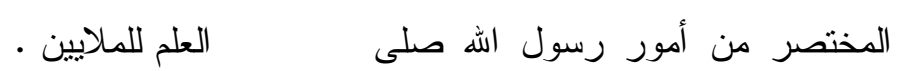

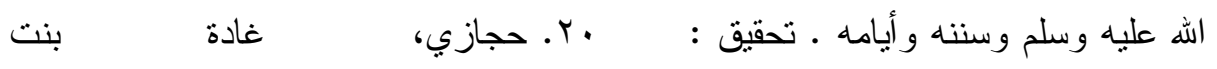

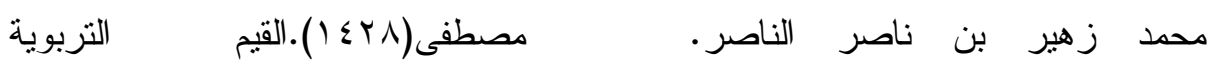

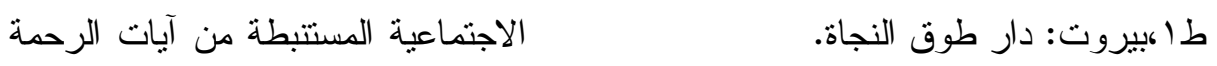

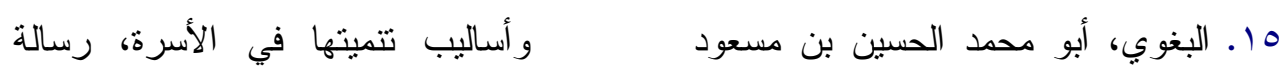

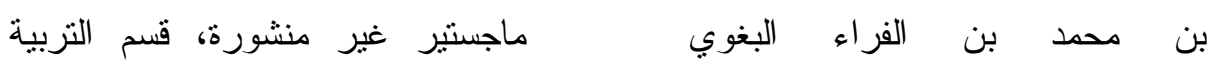

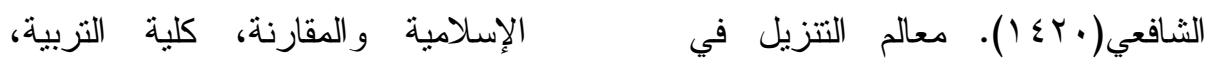

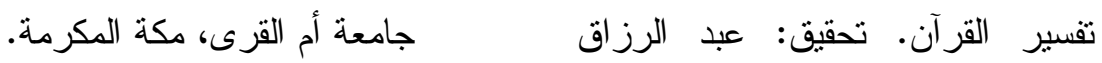




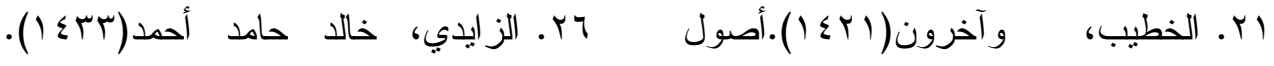

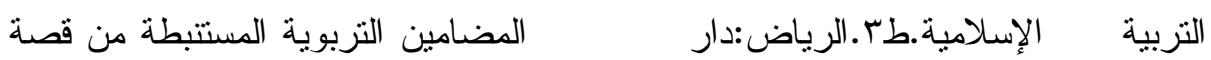

$$
\begin{aligned}
& \text { قارون مع قومه وتطبيقاتها في الأسرة. } \\
& \text { الخريجي للنشر - (النش }
\end{aligned}
$$

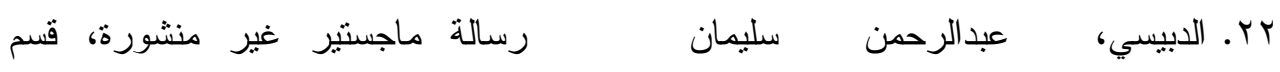

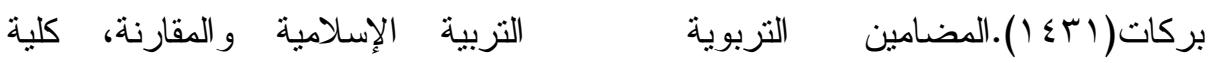

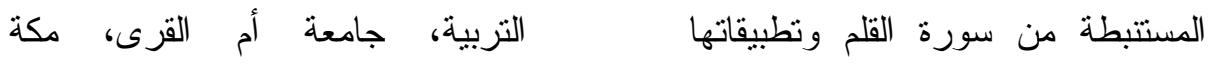

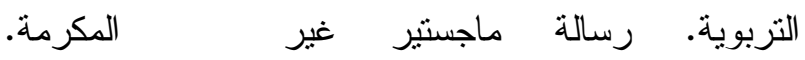

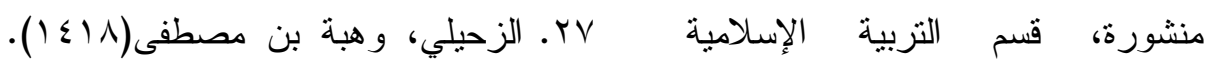

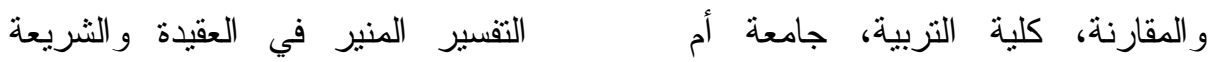

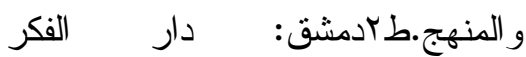

$$
\begin{aligned}
& \text { القرى، مكة المكرمة. }
\end{aligned}
$$

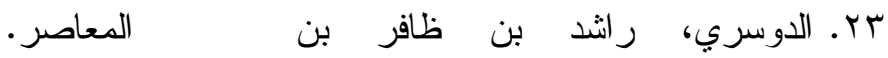

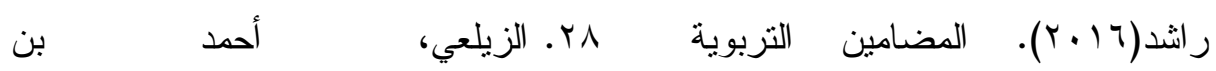

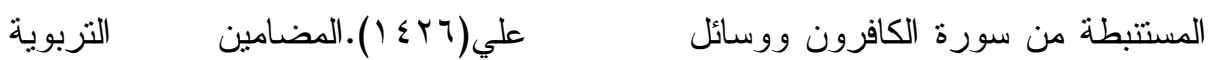

$$
\begin{aligned}
& \text { تعزيزها لدى طلاب المرحلة الثانوية. المستتبطة من سورة الفاتحة وتطبيقاتها }
\end{aligned}
$$

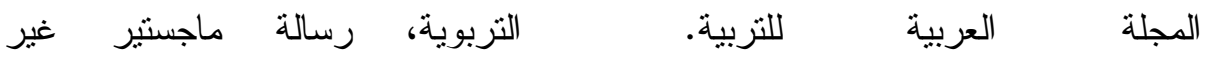

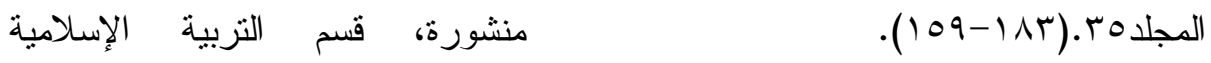

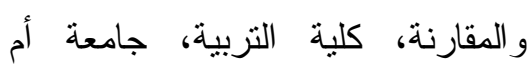

$$
\begin{aligned}
& \text { القرى، مكة المكرمة. }
\end{aligned}
$$

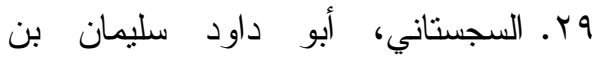

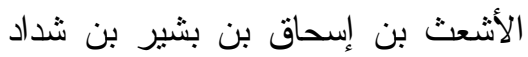

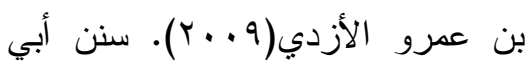

$$
\begin{aligned}
& \text { داود. تحقيق: شعيب الأرناؤوط، محمد الأبرد }
\end{aligned}
$$

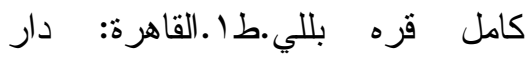

$$
\begin{aligned}
& \text { الرسالة العلمية. }
\end{aligned}
$$

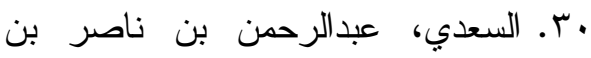

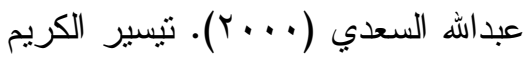

$$
\begin{aligned}
& \text { צr. رجب، مصطفى( } 999 \text { (1).المضامين } \\
& \text { التربوية في قصة ابن نوح. مجلة }
\end{aligned}
$$

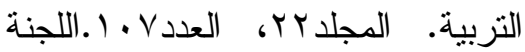

$$
\begin{aligned}
& \text { الوطنية القطرية للتربية والتقافة }
\end{aligned}
$$

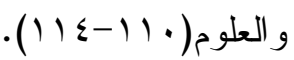

$$
\begin{aligned}
& \text { ه. ـ الرازي، زين الدين أبو عبد الله محمد }
\end{aligned}
$$

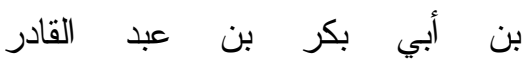

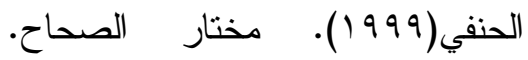

$$
\begin{aligned}
& \text { تحقيق: يوسف الثيخ محد،طه، } \\
& \text { بيروت: المكتبة العصرية. }
\end{aligned}
$$




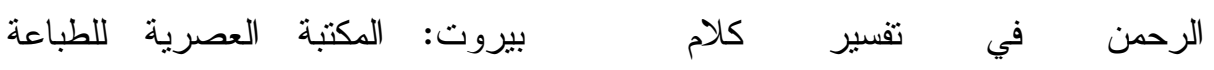

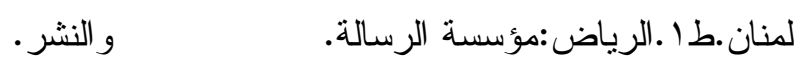

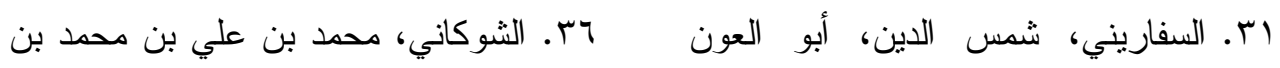

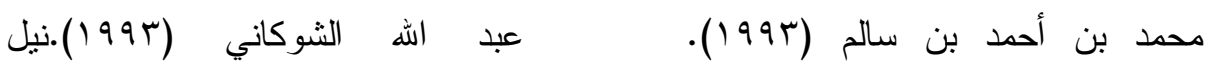

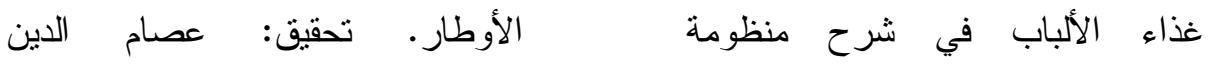

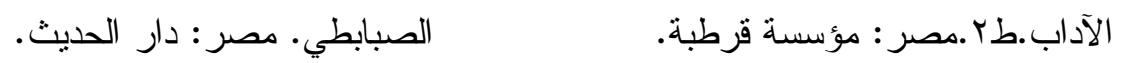

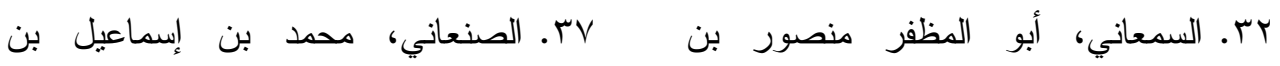

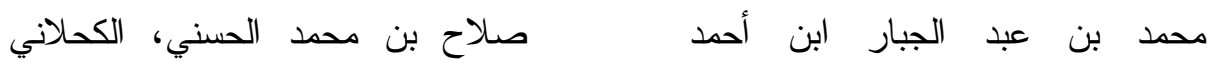

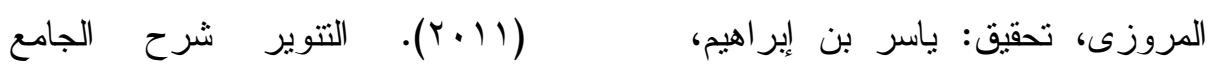

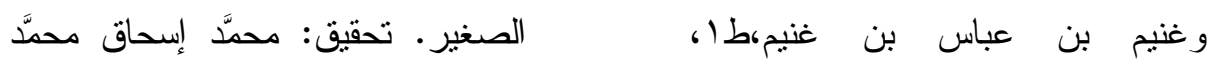

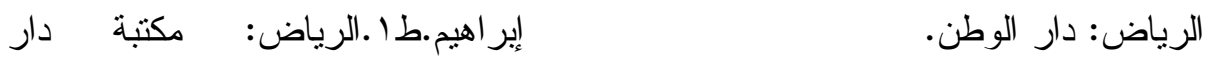

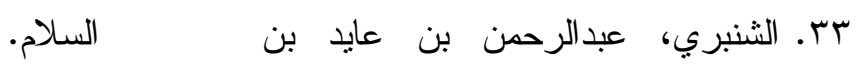

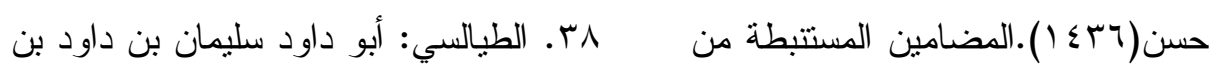

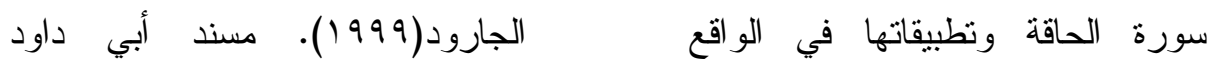

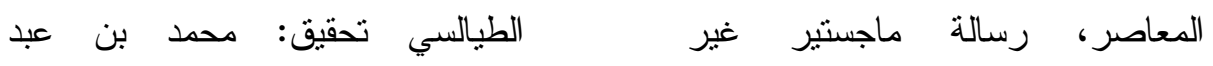

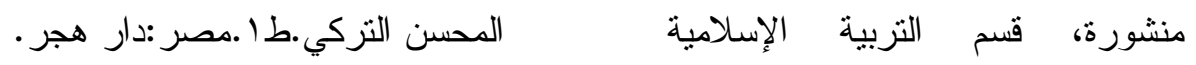

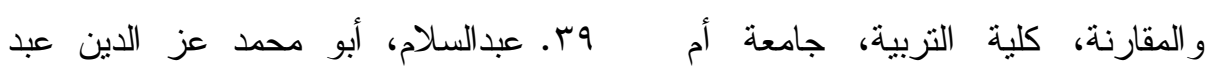

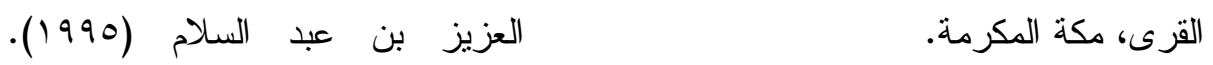

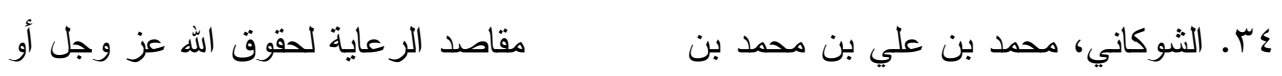

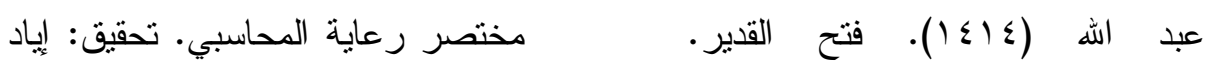

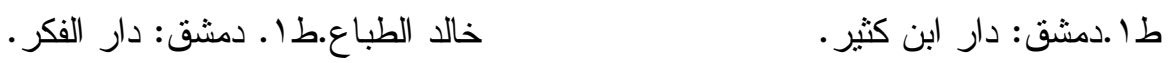

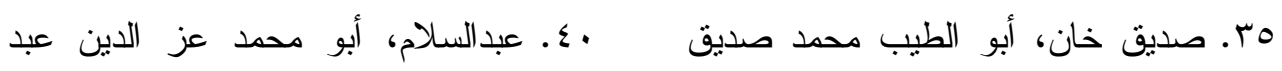

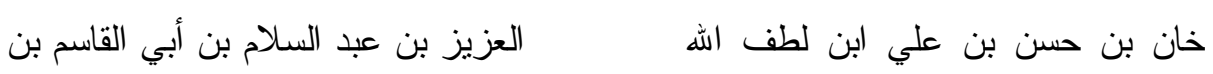

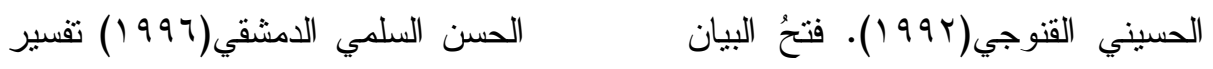

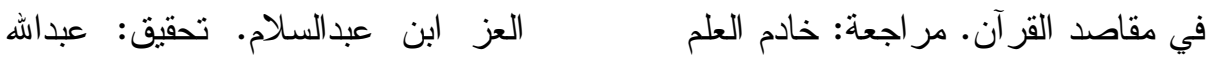

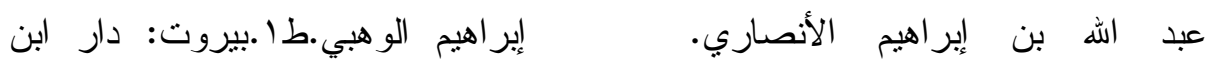

$$
\begin{aligned}
& \text { حزم. }
\end{aligned}
$$




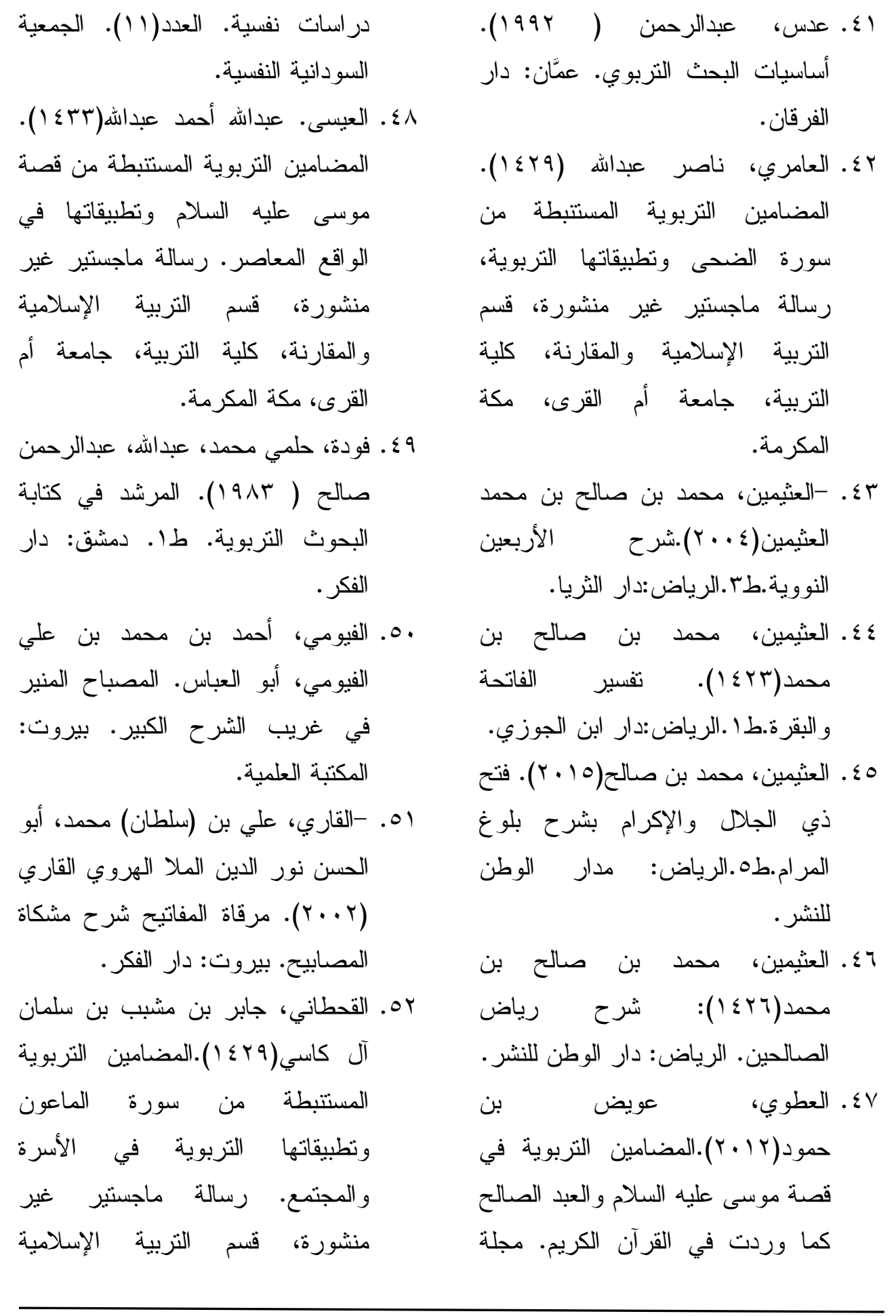




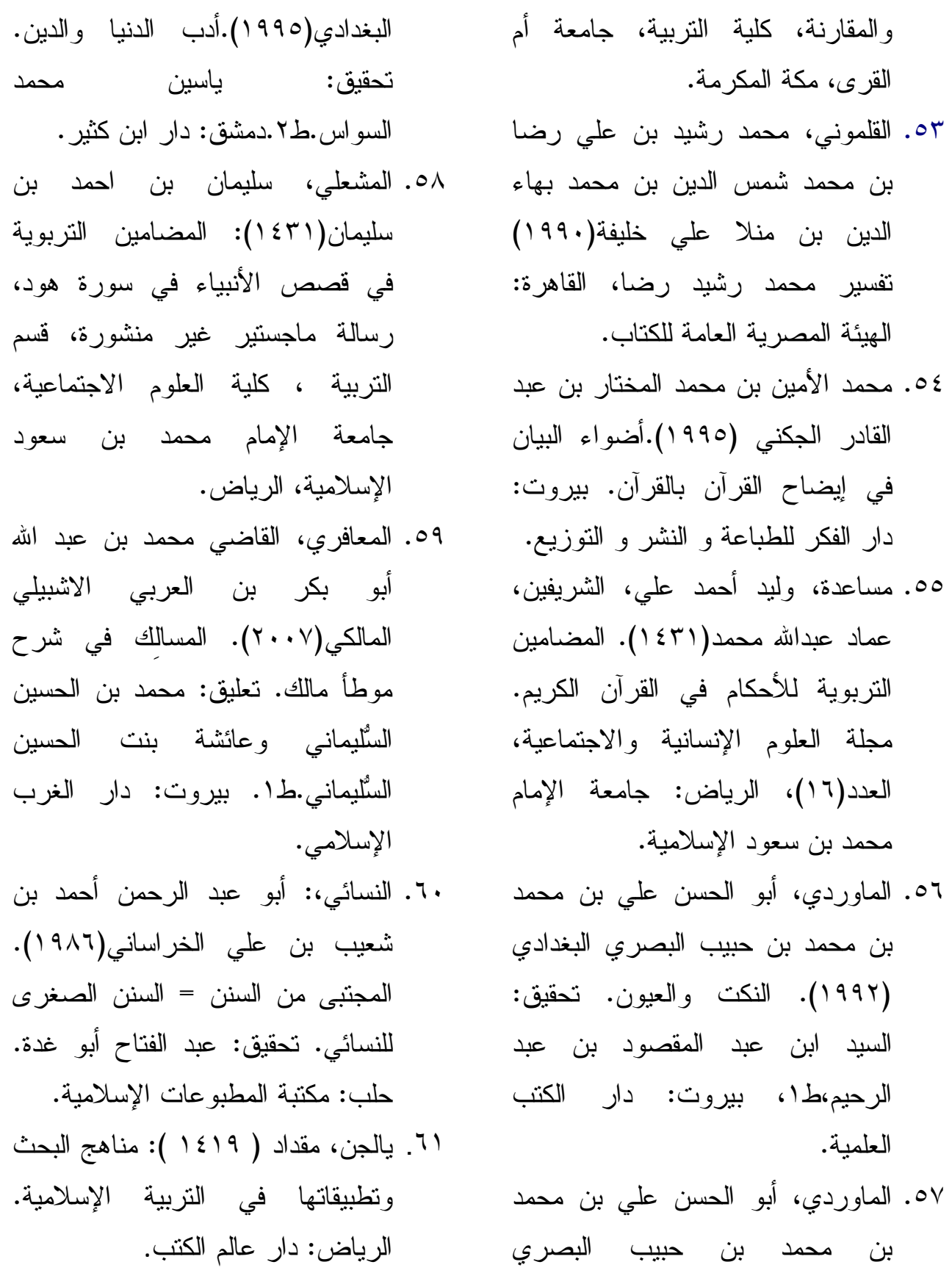

